Portland State University

PDXScholar

$9-27-2021$

\title{
Trump's Legacy in the Middle East: Strategic Shift and the Geopolitics of American Foreign Policy in the Region
}

Bilel Kriaa

Portland State University

Follow this and additional works at: https://pdxscholar.library.pdx.edu/open_access_etds

Part of the International Relations Commons

Let us know how access to this document benefits you.

\section{Recommended Citation}

Kriaa, Bilel, "Trump's Legacy in the Middle East: Strategic Shift and the Geopolitics of American Foreign Policy in the Region" (2021). Dissertations and Theses. Paper 5801.

https://doi.org/10.15760/etd.7672

This Thesis is brought to you for free and open access. It has been accepted for inclusion in Dissertations and Theses by an authorized administrator of PDXScholar. Please contact us if we can make this document more accessible: pdxscholar@pdx.edu. 
Trump's Legacy in the Middle East: Strategic Shift and the Geopolitics of American Foreign Policy in the Region

by

Bilel Kriaa

A thesis submitted in partial fulfillment of the requirements for the degree of

\author{
Master of Arts \\ in \\ Political Science
}

Thesis Committee:

David Kinsella, Chair

Robert Asaadi

Stephanie Erev

Portland State University

2021 
(C) 2021 Bilel Kriaa 


\begin{abstract}
The last six months of the Trump administration witnessed interesting developments regarding its legacy in the Middle East. The normalization of ties between four Arab states and Israel constituted major breakthroughs not only in the regional interstate relations but also for the American foreign policy in the region.

In this context, this thesis offers insights into how to understand and evaluate the administration's approach towards these developments. Based on systematic and empirical research, I analyze a corpus comprised of Trump-era foreign policy documents regarding the Iranian and Israeli-Palestinian questions. I find, firstly, that the Trump administration pursued a strategic shift in the American foreign policy in the Middle East. This shift marked the confrontational "Maximum Pressure" campaign towards Iran and the top-down approach towards the Israeli-Palestinian conflict embodied in the "Peace to Prosperity" plan. Secondly, I find that the Trump administration engineered a geopolitical transformation by pushing the Arab regimes towards a multi-faceted security alignment with Israel. As a theoretical framework, I apply Ryan's 'regime security' theory to Trump's approaches towards Iran and the Israeli-Palestinian conflict. Finally, I conclude that the Trump administration set the stage for a more favorable containment of Iran as the US continues to disengage from the region. It may have even facilitated a return to a strategy of 'Offshore Balancing' in the Middle East in the long run.
\end{abstract}




\section{Dedication}

To my dear host family, Om Matin and Tante Lily. 


\section{Acknowledgments}

I would like to express my deep and sincere gratitude to my supervisor Prof. David Kinsella for his invaluable comments, suggestions, and guidance throughout the different phases of the thesis. I would also like to thank him for showing confidence in my topic. I am indebted to Prof. Robert Asaadi for his valuable time and continuous support. His knowledge, comments, and views helped me sharpen the ideas of this thesis. Special thanks go to Prof. Erev for her feedback and words of encouragement.

This thesis could not have been accomplished without the tremendous support of my family and friends. They all kept me going. I am eternally grateful to each and every one of them.

I am deeply grateful to Prof. Masami Nishishiba whose feedback and expertise helped me refine the methodology of the study.

Special thanks go to Prof. Sofiene Mallouli, Prof. Akila Sellami Baklouti, and Prof. Sadok Dammak for their valuable feedback.

Last but not least, I would like to particularly thank the Fulbright program team, both in the US and Tunisia, as well as the entire faculty staff in Portland State University for their work, coordination, and support in this memorable journey. 


\section{Table of contents}

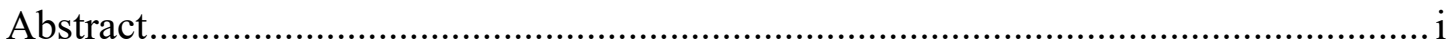

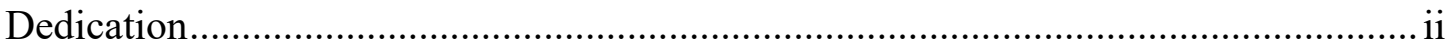

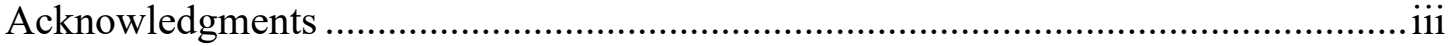

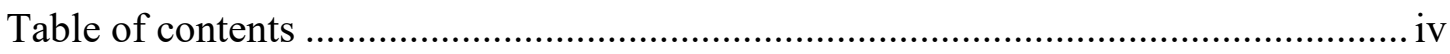

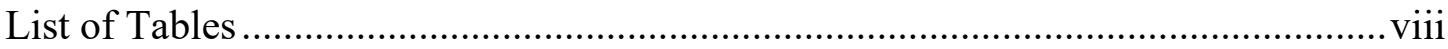

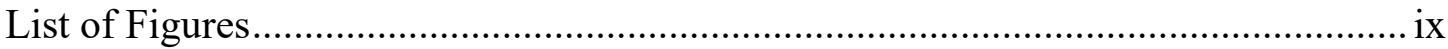

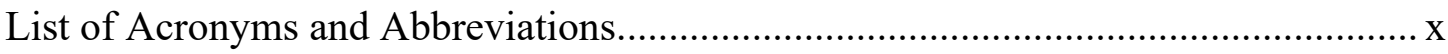

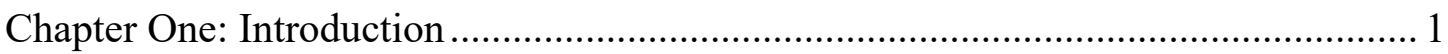

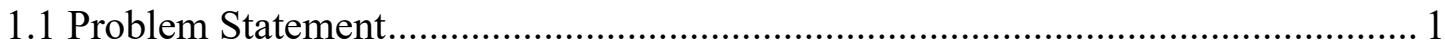

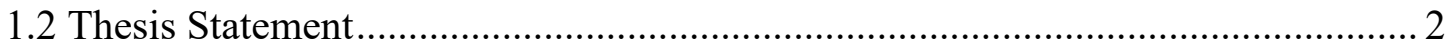

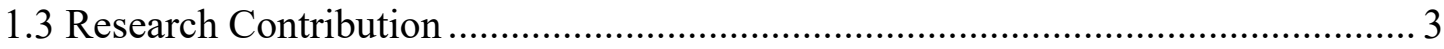

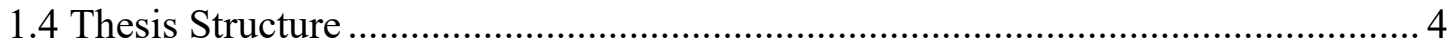

Chapter Two: Historical background and literature review .................................... 6

2.1 US approaches towards Iran's nuclear program before the Trump administration. 6

2.2 The US approaches towards the Israeli-Palestinian conflict before the Trump

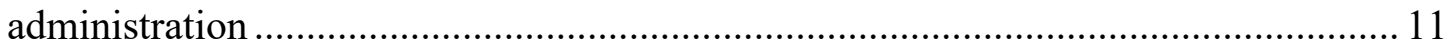

2.3 Trump-era foreign policy in the Middle East: Existing literature and theoretical

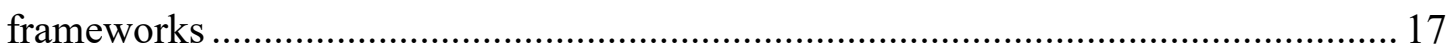

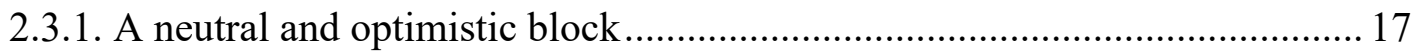

2.3.2. A critical and pessimistic literature............................................................. 19

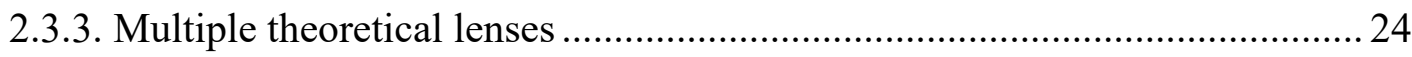

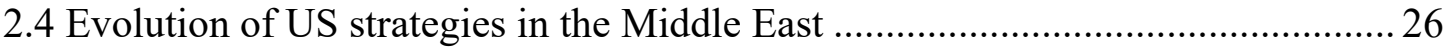

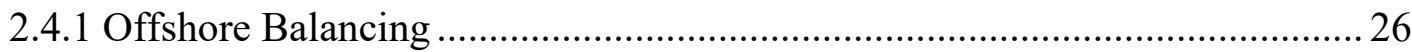

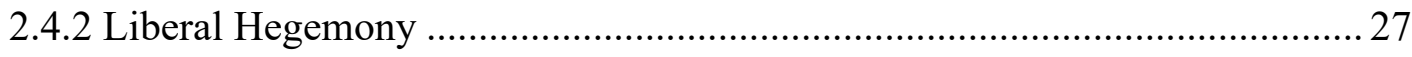

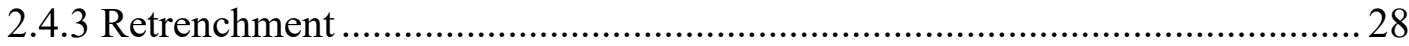

2.5 Regional transformations in the Middle East before the Trump administration ... 29

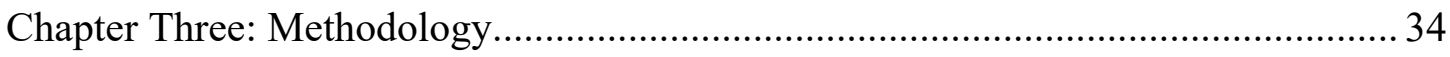

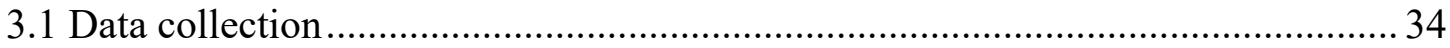

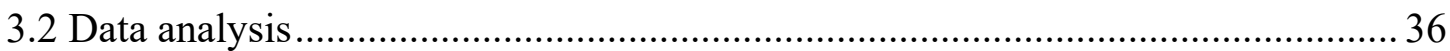




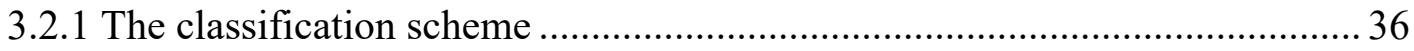

3.2.2 Ryan's 'regime change' theoretical framework.............................................. 40

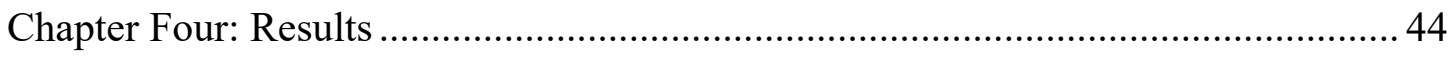

4.1 The adoption of a "Maximum Pressure" campaign towards Iran .......................... 47

4.1.1 Iran and its proxies as the common threat .................................................... 47

4.1.2 A catastrophic Iran Nuclear Deal................................................................ 48

4.1.3 Explicitly criticizing the Obama administration ..............................................49

4.1.4 Criticizing the previous administrations .......................................................... 50

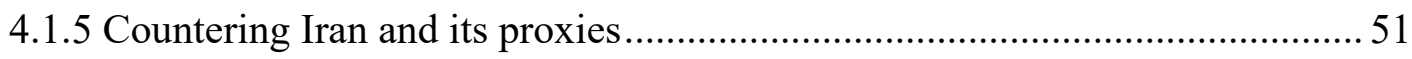

4.1.5.1 The need to counter Iran's destabilizing behavior ..................................... 51

4.1.5.2 President Trump's New Strategy on Iran ................................................. 51

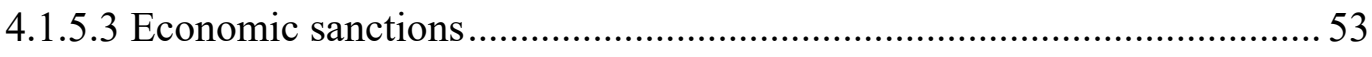

4.1.6 A mixture of multilateralism and unilateralism ............................................53

4.2 The adoption of a top-down approach regarding the Israeli-Palestinian conflict, President Trump's "Peace to Prosperity" plan .........................................................5

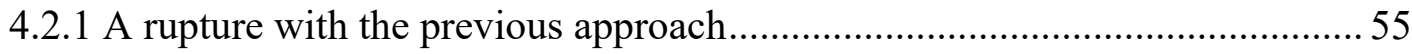

4.2.2 The need for a new realistic approach …………............................................ 55

4.2.3 Bridging the gap between the Arab states and Israel..................................... 56

4.2.4 Triggering a change in perception: sharing common challenges and interests57

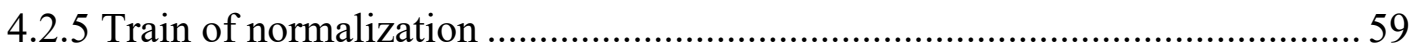

4.2.6 Motives/incentives behind the normalization of relations between the Arab states

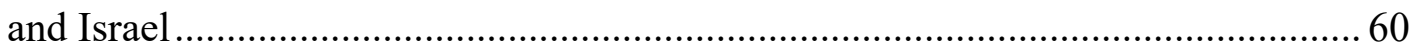

4.2.6.1 Economic motives/incentives to normalize ties between the Arab states and

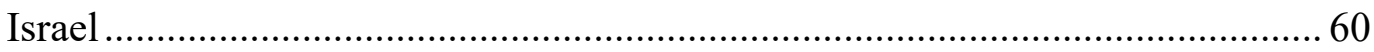

4.2.6.2 Security motives to normalize ties between the Arab states and Israel ... 62

4.2.7 A mixture of multilateralism and unilateralism .................................................6 64

4.2.7.1 Multilateralism through "shuttle diplomacy"................................................ 64

4.2.7.2 Unilateralism: The US approached the Israeli-Palestinian conflict in a manner consistent with its national interests and not necessarily in accordance with

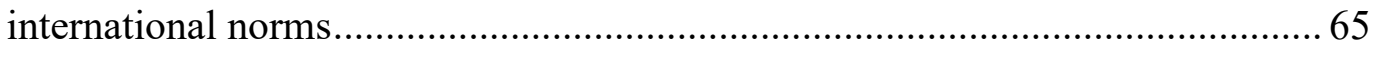

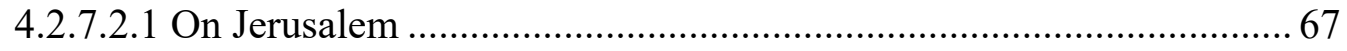


4 2.7.2.4 Limited Sovereignty of the Palestinian State and the maintenance of the security of Israel

4.3. Triggering geopolitical transformation to confront Iran's quest for regional hegemony.

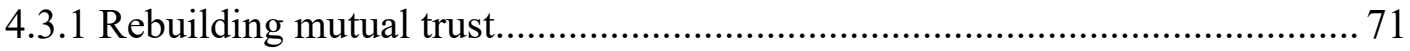

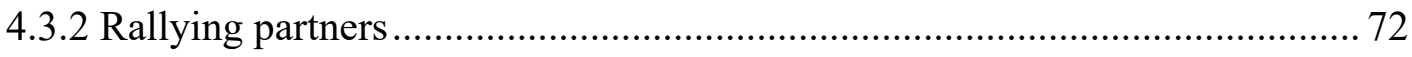

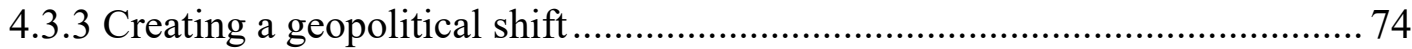

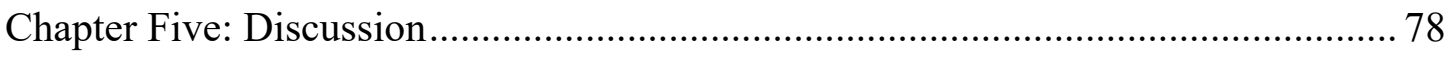

5.1 The adoption of the "Maximum Pressure" campaign towards Iran ..................... 79

5.2 The adoption of a top-down approach regarding the Israeli-Palestinian conflict, President Trump's "Peace to Prosperity" plan ........................................................ 80

5.3 American foreign policy with a heavy dose of unilateralism .............................. 84

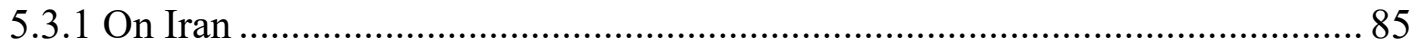

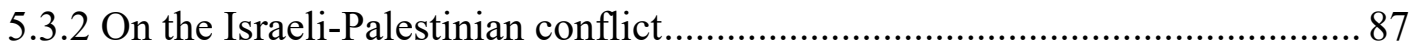

5.3.3 The rationale behind the Trump administration disregard of international

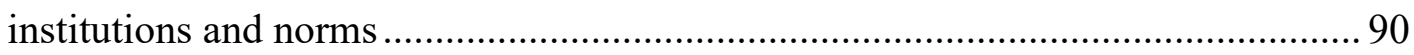

5.4 Triggering geopolitical transformation: An Arab-Israeli security alignment to confront Iran's quest for regional hegemony ................................................... 91

5.4.1 Application of Ryan's three variables on the Trump administration's approach to

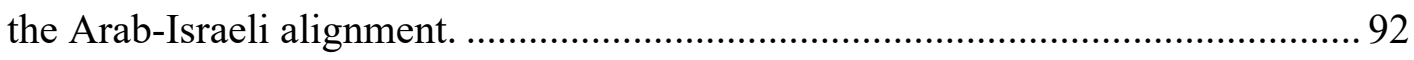

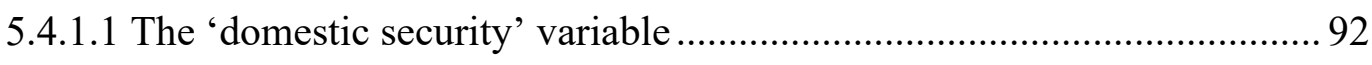

5.4.1.2 The 'political economy' variable ...................................................... 93

5.4.1.3 The 'external security' variable ....................................................... 96

5.4.2 Implications of Trump-era policies on the geopolitical landscape ................ 99

5.4.2.1 Prospects of an Arab-Israeli security alignment ................................... 99

5.4.2.2 The Persian Gulf as the geopolitical ring ........................................ 111

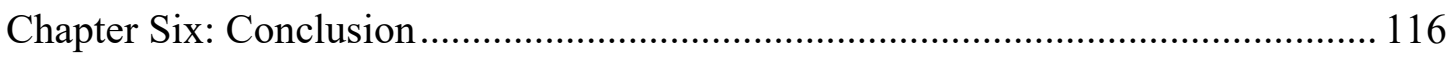

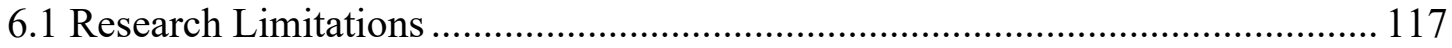

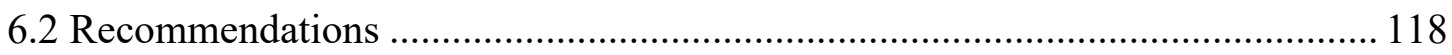




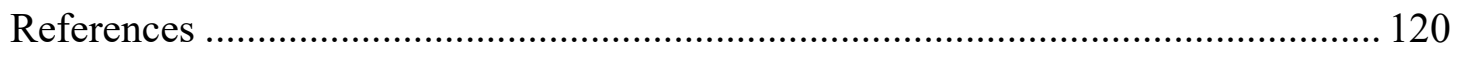




\section{List of Tables}

Table 1: Synthesized findings of the corpus after the content analysis on Quirkos.... 45 


\section{List of Figures}

Figure 1: Final results of the corpus as shown in the content analysis software (Quirkos) .45 


\section{List of Acronyms and Abbreviations}

CENTCOM U.S. Central Command

IRGC The Islamic Revolutionary Guard Corps

IRGCN The Islamic Revolutionary Guard Corps Navy

JCPOA The Joint Comprehensive Plan of Action

MBS Mohammad Bin Salman

OP Operative paragraph

PP Preambular paragraph

UNRWA The United Nations Relief and Works Agency for Palestine Refugees

UNSCR United Nations Security Council Resolution 


\section{Chapter One: Introduction}

\subsection{Problem Statement}

Over the last decades, the US administrations have tried to contain the Islamic Republic of Iran and resolve the Israeli-Palestinian conflict ${ }^{1}$, obviously with different approaches and outcomes. As far as the American foreign policy under the Trump administration in the Middle East is concerned, certain scholars and analysts acknowledge that there was a shift in the way the policies were conducted, nevertheless, the description of this shift remains a matter of contention. Gingrich (2017) argues that this shift is "Titanic" (para. 1) and "decisive" (para. 8). Along similar lines, Quamar (2018, p. 273) views it as "significant" and "visible" in the region. Yet, by contrast, it is advanced that the Trump administration did neither have clear foreign policies (Walt, 2018; Zakaria, 2020) nor a strategy in the Middle East (Cook, 2020).

Drawing on the literature in the field, there seems to be a gap in the knowledge in terms of the examination of Trump's legacy in the Middle East especially after the end of the Trump mandate. In light of the recent and consecutive breakthroughs in inter-state relations in the region, it is undeniable that the normalization of ties between Israel and four Arab states opened a space of discussion in the research field on how to develop a greater understanding and a more thorough evaluation of the Trump-era foreign policies. In fact, it was the Trump administration that triggered and sponsored the train of normalization with Israel. Therefore, the importance of the

\footnotetext{
${ }^{1}$ This research acknowledges the sensitive nature of the Israeli-Palestinian question. Quite aware of the different interpretations surrounding the topic, I adopt the more standard framework in the literature since the focus of this research is to examine the Trump administration's approach to the issue and not offering a reinterpretation of the topic.
} 
Trump endeavors in bridging the gap between UAE, Bahrain, and Israel in addition to the fact that all these states perceive Iran as a common threat has not been well addressed yet in the scholarly works leaving wider questions with regard to how to better approach the Trump's legacy in the region.

So, to what extent did the American foreign policy in the Middle East under the Trump administration change? And how did this shift affect transformations in the region?

\subsection{Thesis Statement}

This thesis argues that the Trump administration pursued a strategic shift in the American foreign policy in the Middle East that could potentially change the geopolitical landscape in the region. This research has two objectives. The first objective is to describe and examine this strategic shift that revolved around two pillars: US policies towards Iran and the Israeli-Palestinian conflict. In relation to the former, the Trump administration unilaterally withdrew from the Iran Nuclear Deal and opted instead for a confrontational muscular campaign of "Maximum Pressure". That was clearly a different approach from the Obama administration's rapprochement with Iran. Similarly, the recent Arab-Israeli peace agreements and the possible ongoing multiple-track negotiations were a result of yet another different approach of the Trump-era foreign policy in the Middle East. This indicated another considerable departure from the previous stances of US administrations towards the Israeli-Palestinian conflict, one that is marked by a top-down approach. Accordingly, I suggest that the importance of this shift on both axes should not be overlooked. Research should not underestimate the extent of this shift; it mirrors a shrewd, 
thoughtful, and masterful strategy that was well calculated and executed by the Trump administration.

Concerning the second objective of this thesis, I attempt to evaluate the implications of these two Trump-era policies at the geopolitical level in the Middle East. I contend that the Trump administration engineered a geopolitical transformation that better fits US disengagement from the region. This transformation is primarily based on a GCC-Israeli security alignment, so strategic for the United States to further contain Iran's influence in the region. This security alignment may represent even a stepping stone towards a return to an 'Offshore Balancing' strategy in the long term. Indeed, according to the Abraham Accords, the security field constitutes an instrumental element in the cooperation between UAE and Bahrain, and Israel. It opens doors for access to territories, intelligence, joint military training, and military and technological partnerships, to name a few. In light of this new regional security alignment, I suggest Ryan's $(2009,2015)$ 'regime security' as an insightful theoretical approach through which Trump's legacy in the Middle East could be understood and evaluated.

\subsection{Research Contribution}

The reconciliation between four Arab states and Israel in 26 years created fresh areas for researchers to better approach Trump's legacy in the Middle East from dimensions the literature paid little attention to. This research contributes to the exploration of the role of the Trump-era foreign policies in the Arab-Israeli rapprochement especially in light of rallying US allies to confront Iran's growing influence in the region. It offers insights into the implications of the strategic shift in American foreign policy in that it lays the ground for a new geopolitical scene based 
on GCC-Israeli security alignment. In a nutshell, in light of the unprecedented rapprochement between some of the Arab states and Israel, and the shared interest by US allies in containing Iran and its proxies, this thesis hopes to better examine the Trump-era foreign policies in the region which proves its importance and significance in the research field.

\subsection{Thesis Structure}

This thesis proceeds as follows. In the first section of the second chapter, 'Historical background and literature review', I outline the US approaches towards Iran since the discovery of its nuclear program and prior to the Trump administration. In the second section, I equally outline the US approaches towards the IsraeliPalestinian conflict before the Trump era. These two sections, relevant to the first research question and objective, are crucial for my discussion, based on my research findings, of the strategic shift in the American foreign policy under the Trump administration.

In the third section, I shed light on some of the relevant literature that addresses Trump's legacy in the Middle East with certain works having favorable views while others are rather pessimistic and critical of Trump's legacy. A third block in the literature just points out particular frameworks through which the Trump-era policies in the region could be understood. The fourth section charts the evolution of US strategies in the Middle East. Finally, the fifth section tackles the literature pertaining to the transformation that the Middle East has recently witnessed. These sections relate to my second research question and objective. They are also crucial for my discussion of the implications of the strategic shift in the Trump-era policies on the geopolitical landscape and regional power dynamics. 
In the third chapter, I explain the methodology that will be used in this research. To demonstrate the strategic shift in the American foreign policy in the Trump era and its geopolitical implications, a corpus representative of different genres of Trump-era foreign policy documents, will be subject to qualitative content analysis. As a theoretical framework, I attempt to use Ryan's $(2009,2015)$ 'regime security' theory to discuss how the Trump administration approached the insecurity of the Arab regimes to push them towards an Arab-Israeli security alignment. In the fourth chapter, 'Results', I feature the findings of the research, and then, in the 'Discussion' chapter, I analyze and interpret them.

In the concluding chapter, I sum up how my corpus findings indicated that the American foreign policy in the Middle East underwent a strategic shift under the Trump administration. This was carried out mostly through a unilateral approach, often inconsistent with international norms, towards both the Iranian and the IsraeliPalestinian questions. Furthermore, my inferences suggest that this strategic shift aimed to alter the geopolitical landscape and advance a security alignment between the GCC regimes and Israel to swing the balance against Iran and its allied groups - in line with the US disengagement from the region. My conclusion also suggests that an Arab-Israeli ${ }^{2}$ security alignment could facilitate the return to an 'Offshore Balancing' strategy in the Middle East in the long run.

${ }^{2}$ By Arab-Israeli, I mean the GCC regimes, Egypt, and Jordan and Israel 


\section{Chapter Two: Historical background and literature review}

In this chapter, I showcase the US approaches, prior to the Trump era, towards Iran's nuclear program and the Israeli-Palestinian conflict. In relation to the Iranian question, the literature suggests that US stances were mostly premised on multilateral cooperation, negotiation, and dialogue. Concerning the Israeli-Palestinian question, the literature also shows the US initiatives put forward to resolve the chronic conflict were mostly in accordance with international norms and consensus. Furthermore, I present the literature regarding Trump's legacy in the Middle East, the evolution of US strategies towards the region, and the transformations that the latter has undergone.

\subsection{US approaches towards Iran's nuclear program before the Trump administration}

It is true that as soon as Iran's quest for nuclear weapons came to the light, the US took an assertive approach towards Iran. Yet gradually it pursued a diplomatic approach based on cooperation with the international community, especially the European allies. There even existed certain occasions where the US pursued a rapprochement with Iran. Whenever Iran chooses to be defiant to international concerns, it faces concerted multilateral sanctions pushed by the US, its allies, and the international community. In what follows, I outline some of the most important stances that punctuated US approaches towards Iran prior to the Trump administration.

Byman and Moller (2016) contend that the prevention of the spread of nuclear weapons represents one of the fundamental US interests in the Middle East. Iran is regarded by the US as a 'rogue' regime fanning terrorism and chaos across the Middle 
East. President George. W. Bush, in his State of the Union message in 2002, included it, along with Iraq and North Korea, in the "axis of evil" that "threaten[s] the peace of the world" (The White House, 2002b, para. 21). John Bolton, former US Ambassador to the UN under the Bush administration, in his testimony before the Committee on Foreign Affairs of the US House of Representatives in 2011, posits that Iran is prone to irrationality and will not be influenced by the "calculus of deterrence" claiming that "A theocratic regime that values life in the hereafter more than life on earth is not likely to be subject to classic theories of deterrence...." (As quoted in Miller \& Bunn, 2013, p. 16). It is in this context that the US deems the proliferation of nuclear weapons as a major threat to its national security and interests. For its part, Iran considers it vitally important to acquire nuclear weapons to protect its own national security, although it always stresses its program is used for peaceful purposes (Fitzpatrick, 2006). Dueck and Takeyh (2007) point out that one of the explanations of Iran's quest for nuclear weapons is the fact that two of its neighboring states endured regime change by the use of force at the hands of the Bush administration.

In addition to the Iran Hostage Crisis, the discovery of Iran's nuclear program was a tipping point in worsening the relations between the US and Iran. Whilst, in December 2002, the international community found out that Iran managed to build two nuclear facilities, in Arak and Natanz, in August 2003, inspectors from IAEA confirmed that they discovered enriched uranium "at rates superior to what is necessary for civilian use" (Security Council Report, 2020, 26 August 2003 section). Notwithstanding sticking to the negotiation track with the international community regarding Iran, El-Khawas (2005) argues the Bush approach was so assertive, and even aggressive, to the point that, during the first term, the administration did not rule 
out the resort to military power against Iran to defend US interest and security. As he puts it, the administration invariably "threatened to take the matter into its own hands" (p. 29) given it was in a mood of unilateralism and regime change in the region.

Yet El-Khawas points out that, during the second term, the Bush stance remarkably changed "becoming more conciliatory and favoring negotiations" (pp. 3233) emphasizing the importance to work closely with the European allies to persuade Iran to eschew a nuclear path. Dueck and Takeyh (2007) affirm that the Bush administration pursued in its second term a multilateral diplomatic path based on negotiation. In their words:

The EU was initially encouraged by Washington to put a number of economic and diplomatic carrots on the table in order to induce Iran to negotiate. Iran's response was so gratuitously uncooperative that the United States was able to win limited economic and weapons-related sanctions against Iran from the UN Security Council in December 2006. (p. 201)

In 2006, when officially rejecting a deal proposed by the EU+3, Iran endured numerous UN sanctions imposed by the UN Security Council. From 2006 to 2015, a range of UNSCRs was adopted regarding Iran's nuclear issues: 1696, 1737, 1747, 1803,1835 , and 1929. Interestingly, the arrival of the Obama administration sparked new prospects for the diplomatic impasse. Wechsler (2019, p. 27) highlights how President Obama, in his Cairo Speech in 2009, invited Iran for diplomatic talks over its nuclear ambitions. President Obama said: "my country is prepared to move forward without preconditions" understandably knowing that "any nation - including Iran - should have the right to access peaceful nuclear power if it complies with its responsibilities under the nuclear Non-Proliferation Treaty". What is much more 
important for Wechsler is that President Obama "downplayed" US assertive portrayal of Iran as a rogue regime that sponsors terrorism by simply referring to it as one that "played a role" in spreading violence. Indeed, this is indicative that the Obama administration eschewed confrontational rhetoric with the Iranian regimes hoping that this would ease the tensions and pave the way for a diplomatic breakthrough.

Meanwhile, the US continued to impose its own sanctions on Iran, targeting an array of sectors ranging from energy to arms to banking (Katzman, 2021). Similarly, the EU reinforced its own economic sanctions on Iran, including a full ban on Iranian oil exports, in retaliation to Iran's suspension of oil exports to the United Kingdom and France in 2012. (Security Council Report, 2020). Despite the severity of sanctions, Iran did not seem to be deterred from moving ahead with its nuclear program. Indeed, by 2015, the Obama administration recognized that Iran possessed "a uranium stockpile" able "to create 8 to ten nuclear bombs" (The White House, 2016, para. 7).

Yet 2015 marked a breakthrough not only for US diplomacy but also for the entire international community in solving one of the most pressing issues in the Middle East. Indeed, the Obama administration reached a deal with Iran regarding its nuclear program. Formally referred to as the Joint Comprehensive Plan of Action (JCPOA), the deal, also commonly known as Iran Nuclear Deal, was signed by the US, Iran, the EU, France, Germany, the UK, Russia, and China. The deal stipulated that Iran halts its nuclear program for at least 10 years in exchange for having the international community lifting the economic sanctions imposed on Iran (U.S. Department of State, 2015). On the importance of the deal, President Obama stressed that it was "a victory for diplomacy, for American national security, and for the safety 
and security of the world" (The White House, 2015, para. 1). Fitzpatrick (2015) affirms that the JCPOA is "A Good Deal" (p. 1). For its part, the United Nations welcomed the agreement with the then Secretary-General Ban Ki-moon describing it as "historic" (UN News, 2015, para. 2). In this regard, in 2015, the UN Security Council unanimously adopted UNSCR 2231 which endorsed the JCPOA. It is worth noting that UNSCRs 1696, 1737, 1747, 1803, 1835, and 1929 were all terminated with the adoption of UNSCR 2231 (Arms Control Association, 2017).

The accord has been strongly criticized by different parties for a myriad of reasons, however. Ben-Meir (2014) summarizes the concerns of the critics about the Iran Nuclear Deal. Firstly, opponents of the agreement argue that this rapprochement with Iran regarding its nuclear program came at a cost which was the unchecked and continuous expansion of Iran in the region. This implied that Iran would benefit tremendously from an economic standpoint since foreign investment would pour into Iran, which in turn could be potentially translated into further support of regional actors notably Hezbollah and Hamas. In the same respect, after 10 years, Iran would have sufficient financial resources to embark on another accelerated program of nuclear weapons. Secondly, it is also argued that the inspection process was loose and gave Iran a major leeway to cheat. For instance, Ben-Meir writes: “despite Iran’s assurances to address UN concerns including the Parchin military site, it did not agree on the intrusive inspection regime that the International Atomic Energy Agency requires to ensure that Iran's programme is peaceful" (para. 23). Put simply, certain pundits argue that Iran cannot be trusted.

Regarding the regime sanctions, certain scholars and analysts question their effectiveness in fending off Iran's nuclear ambitions; on the contrary, they were 
counterproductive by pushing Iran to speed up its nuclear enrichment. By way of example, Gordin and Nephew (2017) point out that, under the effects of the sanctions, Iran increased the enrichment level from 5\% to $20 \%$. Moreover, the number of centrifuges also jumped from 3000 to 22,000 with the construction of more sophisticated and rapid ones. Furthermore, it built another enrichment plant in Fordo (as cited in H. Mousavian \& M. Mousavian, 2017).

In a nutshell, prior to the Trump administration, the US pursued a multilateral approach that considerably used dialogue and negotiation, to contain Iran's program of nuclear weapons. Multilateralism and diplomacy were advanced in the second term of the Bush administration and took momentum during the Obama tenure. It is undeniable that the path toward US rapprochement with Iran was fraught with a plethora of constraints, but the US continued to cooperate with the rest of the international community to address Iran's nuclear aspirations. Particularly, it continued to work closely with its EU allies until it reached the JCPOA. This was remarkably reversed with the Trump administration.

\subsection{The US approaches towards the Israeli-Palestinian conflict before the Trump administration}

In this section, I shall outline the peace initiatives put forward by the US to resolve the longstanding Israeli-Palestinian conflict. Prior to the Trump mandate, the US administrations suggested several plans that were relatively in concurrence with the international consensus that punctuated the Israeli-Palestinian conflict.

In 1978, the Carter administration was deeply involved in the peace talks between Egypt and Israel which led to the famous Camp David meeting in the US. These diplomatic efforts eventually came to fruition with the signature of a formal 
peace treaty between Egypt and Israel in 1979. Dubbed the Camp David Accords: The Framework for Peace in the Middle East, the peace treaty insisted that genuine and durable peace between the Arab neighboring states and Israel should be "based on Security Council resolutions 242 and 338 in all their parts" (National Archives, 2021, para. 10). In 1982, President Ronald Reagan presented his administration's peace plan in a public speech in September 1982. The Reagan Middle East Initiative signaled the US longstanding support for the security of Israel but also highlighted "the legitimate rights of the Palestinian people and their just requirements" (para. 24). He stressed the importance of compliance with UNSCR 242 which he described as "wholly valid" and that "in return for peace, the withdrawal provision of Resolution 242 applies to all fronts, including the West Bank and Gaza" (para. 32). Equally important, President Reagan pointed out that the US stance "on the extent to which Israel should be asked to give up territory will be heavily affected by the extent of true peace and normalization, and the security arrangements offered in return" (para. 32). On the question of settlement, President Reagan called for "the immediate adoption of a settlement freeze by Israel" (para. 28) in an attempt to inject a dose of confidence in the Arab parties to initiate serious talks. Regarding the refugee issue, he said: "Palestinians feel strongly that their cause is more than a question of refugees. I agree" (para. 24). Finally, concerning the final status of Jerusalem, President Reagan stated that only negotiations should solve the dispute, although he emphasized that the city "must remain undivided" (United Nations, 1982, para. 31). It is worth noting that before President Reagan suggested his plan, there was another peace initiative called "The Fahd Peace Plan" put forward by Crown Prince Fahd bin Abdul Aziz of Saudi 
Arabia. The plan, comprising eight major points to resolve the conflict, was based on UNSCRs 242 and 338, and the pre-1967 borders (Razvi, 1981).

For his part, President George. H. W. Bush suggested a peace plan, in a speech before the Congress in March 1991, which revolved around the spirit of UNSCR 242. Interestingly, the American foreign policies under the first Bush administration underwent a significant shift from the Reagan administration regarding its support to Israel. The then-Secretary of State James Baker exercised pressure on the Israeli Prime Minister Yitzhak Shamir to put an end to the Israeli settlements in the West Bank and Gaza Strip. He went as far as to warn the Israeli government that, in case the settlement activities were not halted, the US would not ensure that Israel obtains loan guarantees worth $\$ 10$ billion to absorb Jewish immigrants from the former Soviet Union. Eventually, this led to acute tensions between President Bush and PM Shamir (Tessler, 2020). The Office of the Historian (2016a) corroborates that "The failure of the plan, combined with sharp U.S.-Israeli exchanges over Israeli settlement-building in the occupied territories, strained relations between Bush and Shamir" (para. 4).

When it comes to the Clinton era, it is interesting that, at the beginning of its mandate, the Clinton administration relatively pursued a top-down approach to the Israeli-Palestinian conflict but failed. The administration tried to strike a peace deal between Israel and Syria prioritizing it over a direct solution between the Israelis and the Palestinians. The Clinton administration thought it would be more practical to find common grounds between Israel and Syria as the former could easily withdraw from the Golan Heights, which was not the case for the West Bank due to its complexity. The rationale behind prioritizing neighboring states to Israel over the Palestinians was also hoping for a 'spillover effect' that could trigger Lebanon to think seriously about 
a peace agreement with Israel. In light of this, the Clinton administration oriented its focus and efforts to an Israel-Syria agreement and managed to bridge the gap in the negotiation before it reached a dead end due to disagreement on to what extent would Israeli withdraws from the Golan Heights (Office of the Historian, 2016b).

During 2000, the Clinton administration made a few diplomatic attempts before leaving office. Of paramount importance is the Camp David II initiative hosted by President Clinton in July. The Clinton offer revolved around three major pillars. The first one was that the future Palestinian State will encompass the entire Gaza Strip and more than $90 \%$ of the West Bank. The second one proposed that Palestinians will be granted control over The Temple Mount/Haram al-Sharif in Jerusalem. The third pillar was a considerable recompensation for the refugee issue. Although the negotiations lasted a couple of weeks, the outcomes fell short of the expectations (Rosenberg, 2011). In light of the failure of Camp David II, the Clinton administration crafted another initiative known as the "Clinton Parameters". President Clinton insisted that if the new offer, in line with Resolutions 242 and 338, is not accepted, it will vanish when his mandate is over. Presented in his meeting with the Israeli and Palestinian delegations on December 23, 2000, President Clinton's new proposal envisioned a Palestinian state comprising of between 94 and 96\% of the West Bank territories, in addition to an exchange of between 1 and $3 \%$ of Israeli territories as a recompensation for the Israeli settlements in West Bank. Regarding Jerusalem, while the Palestinians will exercise sovereignty over the Haram, the Israelis will exercise sovereignty over the Western Wall. Concerning the refugee question, President Clinton "believe[s] that Israel is prepared to acknowledge the moral and material suffering caused to the Palestinian people as a result of the 1948 war" and called for 
its cooperation with the rest of the international community regarding "compensation, resettlement, rehabilitation, etc" (United States Institute of Peace, 2001, p. 2).

Under the George W. Bush administration, a new multilateral initiative to resolve the Israeli-Palestinian conflict saw the light. Dubbed the 'Road Map for Peace', also known as the 'Road Map', the peace plan was developed by the United States, the United Nations, the European Union, and Russia. Referred to as "the quartet", these parties worked for hand in hand and endorsed a two-state solution based on previous UN Security Council resolutions. The initiative was first suggested by President Bush in a speech delivered on June 24, 2002, in the Rose Garden. President Bush was hopeful that "the Israeli occupation that began in 1967 will be ended through a settlement negotiated between the parties, based on U.N. Resolutions 242 and 338, with Israeli withdrawal to secure and recognize borders" (para. 20). Regarding the question of Jerusalem, President Bush said that both parties must work together to settle their disputes about Jerusalem. Equally important, President Bush also stressed the importance of finding a solution for "the plight and future of Palestinian refugees", in addition to the establishment of peace between Israel and its Arab neighbors (The White House, 2002c, para. 21). Notwithstanding the international endorsement of such a plan, the 'Road Map' bore no fruits.

Following the Beirut Summit in 2002, a prominent Saudi-led Arab initiative, in accordance with UNSCR 242 and 338, was offered to Israel. Dubbed The Arab Peace Initiative, unanimously adopted by the Arab League, the plan stipulated a twostate solution based on the pre-1967 borders. In exchange for that, the Arab states would recognize the existence of the state of Israel in addition to the establishment of diplomatic ties with it. East Jerusalem had to be the capital of the Palestinian state, 
with the latter encompassing both the West Bank and Gaza strip. Regarding the refugee question, the initiative insisted on the "Achievement of a just solution to the Palestinian refugee problem to be agreed upon in accordance with U.N. General Assembly Resolution 194” (Al-bab, 2002, OP 2-II).

In line with the previous administrations, the Obama administration attempted to broker peace between the Israelis and the Palestinians in compliance with international consensus. As underscored by Tessler (2020), President Obama delivered a powerful speech in May 2011 advocating for the creation of an independent Palestinian state in accordance with the pre-1967 borders. In this regard, Tessler states that Secretary of State John Kerry invested heavily in the quest for a peace deal between the two parties. Whilst Secretary Kerry succeeded in reigniting peace talks that managed to bring the Israelis and Palestinians to one table for negotiation, his initiative failed in less than a year. The Obama administration's stance towards the conflict strained relations with the Israeli government under the leadership of Prime Minister Benjamin Netanyahu, however. This was evident in the US decline, in December 2016, to veto a UNSC Resolution that condemned Israeli continuous settlements on the lands it annexed since 1967. Indeed, it was a significant move from the United States in the UN Security Council that rejected the ongoing Israeli settlements in the occupied territories. In the same respect, in his final speech, Secretary of State John Kerry rebuked the Israeli settlements and indicated that they continued to constitute a hurdle in establishing meaningful peace between the Israelis and Palestinians (Sanger, 2016).

To sum up, US peace initiatives and endeavors, prior to the Trump administration, did not move away from the internationally backed track to resolve 
the Israeli-Palestinian conflict. Issues such as the Israeli settlements in the West Bank, the status of East Jerusalem, as well as the Palestinian refugee question, were noticeably recognized by the US administrations from both sides of the aisle. Nevertheless, it should be noted that historically, the protection of Israel has been considered a US national interest across the different administrations, be they, Republican or Democrat. This special relationship rests on three premises: security interests, shared values, and domestic support (Byman \& Moller, 2016; Erdoğan \& Habash, 2020). In fact, since 1972, the US has frequently activated its veto power in the UN Security Council to defend Israel from any form of condemnation or criticism. The Jewish Virtual Library (n.d.) tracks all the vetoes the US used to reject resolutions against Israel.

\subsection{Trump-era foreign policy in the Middle East: Existing literature and}

\section{theoretical frameworks}

Quamar (2018) suggests that the Trump-era foreign policies have been "primarily focused on West Asia" (p. 272). Thus, it comes as no surprise that Trump's legacy in the Middle East ignited a fierce debate in the scholarly field. Indeed, the literature on Trump's legacy in the Middle East can be broken down into 3 main blocks. Whilst it produced a flood of criticism at several levels, a growing body of scholarship also shows that there were several positive aspects of Trump's legacy in the region. A third block rather addresses the different theoretical lenses from which the Trump-era American foreign policy could be approached.

\subsubsection{A neutral and optimistic block}

Quamar (2018) argues that it took the Trump administration only a year and a half to showcase a "significant" (p. 273) and "visible departure from the Obama's 
policy in West Asia" (p. 272). For him, the departure in American foreign policy is manifested in three policies. Firstly, President Trump left US military bases in Syria, even though ISIS was defeated. He also militarily hit the Assad regime twice to punish its use of chemical weapons whereas Obama refrained from doing so. Secondly, he moved ahead with the moving of the US embassy to Jerusalem. Thirdly, President Trump reversed Obama's rapprochement with Iran.

Boys (2021) stresses that "it must be recognised that there were successes associated with the Trump presidency" (p. 29), among which was the Abraham Accords, despite the appointment of Jared Kushner, a state developer, which understandably raised the eyebrows of critics. Feith and Libby (2020, p. 38) argue that the Trump approach to the Israeli-Palestinian conflict succeeded in shattering the longstanding concern of the "Arab street". The US used to take Arab public opinion into consideration for fear that its interests in the region would be in jeopardy. Yet with the Trump administration's recognition of Jerusalem as the Capital of Israel as well as the "Peace to Prosperity" plan, Feith and Libby assert that "arguments about the "Arab street" will be evaluated with skepticism" as far as American foreign policy towards the conflict is concerned.

In his assessment of Trump's foreign policies, Blackwill (2019) writes a report in Council on Foreign Relations entitled Trump's Foreign Policies Are Better Than They Seem. In the Middle East section, Blackwill focuses on American foreign policies towards Iran, Syria, and Israel, among other states. In relation to Iran, Blackwill justifies US withdrawal from the JCPOA and highlights its flaws yet notes President Trump suggested no alternative. Overall, he contends that, contrary to the predictions of a score of pundits, the withdrawal from the accord did not have serious 
consequences despite the absence of a clear alternative for the deal. With regard to Syria, Blackwill views that President Trump has pursued the right policies in Syria. In the beginning, he concurs with some pundits that the Trump administration's policies in Syria were inconsistent, ambiguous, and confusing. He mentions how President Trump had surprisingly declared that the US would withdraw its troops in Syria before he stepped back after some members of his administrations, such as Secretary of Defense James Mattis, publicly contradicted him. However, Blackwill argues that President Trump was not wrong to pull out US troops from Syria since the primary US mission was to defeat the Islamic State, which was the case for Blackwill. Concerning US relations with Israel, Blackwill points out that President Trump was no different from his predecessors in terms of their support to Israel, although President Trump has invested more in the US ally, both militarily and diplomatically. He writes that the president's decision to move the US embassy to Jerusalem "was the right step to take and did not produce the harms that critics predicted" (p. 47), although his administration could have traded the decision with halting the Israeli settlements. On the annexation of the Golan Heights by Israel, Blackwill draws attention that Trump's recognition of such a move would further exacerbate the situation in the Middle East.

\subsubsection{A critical and pessimistic literature}

In an article in the Foreign Policy magazine entitled "Trump's Middle East Legacy Is Failure", Cook (2020) acknowledges that President Trump achieved a certain level of success in the Middle East, yet argues he neither presented nor pursued a clear, harmonious, and comprehensive strategy. Cook writes: "the president has had a handful of successes — but never anything approaching a strategy" (subtitle). 
Cook claims that "the only way to describe U.S. policy in the region is "strategic incoherence" (para. 2). Cook metaphorically depicts Trump's view of American foreign policies in the Middle East, and more generally in the world, as driven by a Lazy Susan approach. One day, President Trump focuses on Syria. The next day is on NATO. The day after, his focus would be shifted to Venezuela or Iraq and so on. On Iran, Cook praises the US killing of General Qassim Soleimani yet affirms, what Blackwill (2019) already mentioned, that such a move fell short of a clear strategy on Iran, despite the "Maximum Pressure" campaign. Regarding President Trump's "Peace to Prosperity", Cook argues that it was unrealistic in its suggestions, thus it has not gone that far after the Palestinians categorically rejected it. He writes: "When it became clear that the Palestinians were not interested in such a one-sided deal, the president lost interest" (para. 6). This does not mean that Cook does not admit Trump's success in the Abraham Accords as well as the more recent normalization of ties between Israel and Sudan, however. What Cook seems to miss in his evaluation of US strategy in the Middle East is that the Trump administration pursued a top-down approach to the Israeli-Palestinian conflict in the sense that it pushed for the normalization of ties between the Arab states and Israel at the expanse of the Israeli-Palestinian reconciliation. Allied to Cook's analysis is the view of Zakaria (2020) who writes: "Trump does not have a foreign policy. He has a series of impulses — isolationism, unilateralism, bellicosity — some of them contradictory" (para. 6). By way of example, Zakaria states that the Trump administration's policies on Syria were ambiguous, inconsistent, and conflicting. He mentions how President Trump had surprisingly declared that the US would withdraw its troops in Syria before he refrained from doing so. For his part, Walt (2018) goes as far as to assert 
that the Trump-era "foreign policy is essentially a chaotic, confusing, and inept version of his predecessors' approach" (pp. 16-17).

Along similar lines, Wechsler (2019, p. 29) argues that the Trump-era foreign policy in the Middle East has been marked by inconsistency, unpredictability, and erraticism with regard to an array of issues in the Middle East. He maintains that certain leaders in the Middle East hoped to see a "return to normalcy" in the American foreign policy with the election of a new President in 2016, after a period of status quo revision under the Bush administration and uncertainty under the Obama administration. "Instead, President Trump has already proven to be even more inconsistent and unpredictable, and even more willing than either of his last two predecessors to depart from longstanding American policy norms".

Azizi et al. (2020) argue that the "Maximum Pressure" campaign failed to halt Iran's destabilizing behavior in the region, even though it succeeded in crippling the Iranian economy. Iran embarked on a program to develop its capabilities in missiles and navies. Furthermore, it further invested in its anti-containment resistance premised on "asymmetric deterrence" (p. 159). This included strengthening its relations with its militant proxies and helping them develop their drone and missile capabilities such was the case with the Houthis and Hezbollah. Moreover, it proved it could retaliate against the US pressure such was the case when it shot down the Global Hawk drone in June 2019 by the Third of Khordad, a locally advanced air defense system. In short, for Azizi et al., the Trump administration's “Maximum Pressure" campaign was counterproductive as threats facing the US interests in the region further intensified. It simply led to an Islamic Republic's "maximum resistance" (p. 156). 
Katzman (2021) corroborates that the "Maximum Pressure" campaign did not manage to curb Iran's alleged destabilizing activities across the region. It is true that Iran dwindled its fighters in Syria. Furthermore, according to Brian Hook's testimony to the Senate Foreign Relations Committee in 2019, from 2017 to 2018, the Iranian regime reduced the defense budget by 28 percent and the IRGC one by 17 percent. Moreover, Hezbollah, facing serious economic problems, had to resort to donations, among other things, to fund its operations and pay its fighters. In addition to that, the Iranian regime itself witnessed sporadic waves of unrest in 2017, 2018, and 2019 in light of the deteriorating socio-economic conditions due to the economic sanctions. Yet in spite of these challenges, Iran did not succumb to the American pressure. Its regime proved to be quite resilient. Iran remains entrenched in the Syrian and Yemeni civil wars but also in Iraqi and Lebanese affairs. In this regard, Katzman suggests that the imposition of tough sanctions on Iran, even before the Trump administration's economic campaign, had "minimal effect on Iran's regional behavior" as it "has remained engaged in these regional conflicts" (p. 50). Equally important, the Trump administration's approach did not preclude Iran from moving forward with its nuclear weapon program. Indeed, in February 2020, Secretary of State Antony Blinken declared that it would take Iran "a matter of weeks" (para. 2) to develop a nuclear bomb if it did not end its violation of the terms of the Iran Nuclear Accord (Obaid, 2021), which is indicative of the limitations of the Trump administration's policies towards Iran.

In the same vein, the Trump administration's "Maximum Pressure" campaign might be counterproductive in reaching another accord with Iran. Katzman (2021) points out that the campaign led to a surge of hardliners elected to the Iranian 
parliament, who secured a landslide victory in the parliamentary elections held in February 2020, while at the same time weakening President Rouhani who is more open to negotiations with the US. Indeed, in late February 2021, Iran lawmakers called for the prosecution of President Rouhani following his alleged violation of a law passed in December 2020. This law obliges the Iranian government to halt the voluntary implementation of the Additional Protocol under the JCPOA in an attempt to restrict IAEA inspection of nuclear-related sites (Motamedi, 2021). Even though the call for punishing the Iranian government was disputed by the Supreme National Security Council, it was illustrative of the critical stance that the Iranian parliament has in relation to future negotiations with the US.

From a different perspective, Solhdoost (2018) argues that the Trump administration has reduced American foreign policy to a mere transactional business between the US and its allies and adversaries alike. He offers an explanation of Trump's foreign policies based on a transactional framework. For Solhdoost, this approach rendered US national interests and the President's personal interests intertwined and overlapped, posing a real danger to US interests abroad. In addition to the outpouring of millions of dollars of campaign donations and investments for the Trumps and the Kushners' business, Solhdoost points out how President Trump appointed his closest friends to senior positions, although they may lack the required diplomatic experience such as was the case with the US Ambassador to Israel, who served as Trump's bankruptcy lawyer. It is in this context that Solhdoost asserts that Israel took advantage of the business interests that drive both the Trump and Kushner families to steer the American foreign policy in the Middle East in the way it wants, 
as was illustrated in the withdrawal from the Iran Nuclear Deal and the relocation of the US embassy to Jerusalem after recognizing the latter the capital of Israel.

\subsubsection{Multiple theoretical lenses}

A third block in the literature concerns the scholarly work that attempts to understand American foreign policy from different lenses. The literature addressed Trump's legacy in the Middle East from theoretical perspectives related to structural dynamics, populism, and Jacksonianism, among other angles.

Yom (2020) claims that, in the Trump era, the Middle East witnessed a "decline" of the US "hegemonic" role (p. 75). He traces this back to the Obama administration which started to retreat from the region largely due to structural factors, mainly "the end of severe threats" (p. 81). Accordingly, the Trump administration "logically follow[ed] this downward arc of involvement" (p. 80) in the affairs of the region. Yom expects that the US will continue to withdraw from the Middle East and pursue a strategy of 'Offshore Balancing' in an attempt to rebalance the cost of maintaining order in the region. As a consequence, this will trigger a change in the geopolitical terrain as Russia and China will be allowed to play a bigger role in the arena. Similarly, Quamar (2018) maintains that "the common chord between Obama's legacy and Trump's policies in West Asia is that the USA is losing ground to emerging global powers" (p. 272), mainly Russia and China, although the US will continue to play the role of security guarantor, indicating a shift in the geopolitical arena in the Middle East.

Hassan (2020) argues that the American foreign policy under the Trump administration was driven by an 'America First' policy paradigm. Hassan's research reveals that President Trump used populism as a major framework in his speeches and 
linked it explicitly to the dire consequences of the 2008 financial crisis. His research meticulously scrutinizes the discursive-ideological formations of the 'America First' paradigm. He examines a corpus of 3,114,973 words emanating from the speeches of President Trump between 2015 and 2017. Hassan finds that "prescriptions of American decline were consistently articulate with an imperial right over the Middle East” (p. 134). This is evident in the President's recurrent assertion about ensuring the control of the oil in the region, by insisting on the US right to "take the oil", which illustrates "a desire for an imperium par excellence" (p. 134). Cha (2016) also confirms that Trumpism was triggered by, among other factors, the worsening socioeconomic conditions that accompanied the global economic crisis of 2008 and how it crippled the working and middle classes in the US.

Hassan suggests that the Trump administration attempted also to assert US imperial power over the Middle East through its endeavor to create an "Arab NATO". Hassan goes on to state that the formation of such an alliance would "somehow institutionalize America hegemony by bringing the Gulf powers together to balance against Iran and Chinese interventions", similar to the creation of the Central Treaty Organization, also known as the Baghdad Pact, which is very important given "the parameters of a limited US commitment" (p. 135). He claims that such an attempt is "Doomed to failure" (p. 135) and that the Trump administration will rely on "the authoritarian strongman model of imperial control” (p. 125) instead. In this respect, he cites two examples: the unconditional support for Saudi Arabia as illustrated in the impunity of the Al-Saud family regarding the assassination of Saudi dissident Jamal Khashoggi and President Trump calling President Abdel Fattah El-Sisi of Egypt “where's my favorite dictator?” (p. 136). 
From a different perspective, Clarke and Ricketts (2017) argue that the Trump administration follows the Jacksonian tradition of American foreign policy as distinguished by Walter Russell Mead. They state that President Trump taps on the principles of populism and the possible use of military power. By the same token, Ettinger (2020) corroborates that President Trump adopts the Jacksonian school of foreign relations by his embrace of a certain form of "populist sovereignty" (p. 411). The latter is associated with US leaders' commitment to the service of the American public, the 'folk community'. It is within this context that Jacksonians do not prefer international commitments that restrict US sovereignty and curb its freedom. Cha (2016) affirms that the Trump administration embodies Jacksonianism in that it holds deep-seated suspicion about multilateralism and international laws. He underscores that candidate Trump "suggested neo-isolationist and neo-sovereigntist countermeasures... against dominant multilateralism or globalism" (p. 89).

\subsection{Evolution of US strategies in the Middle East}

\subsubsection{Offshore Balancing}

Mearsheimer and Walt (2016) and Walt (2018) contend that, during the Cold War, the US adopted an 'offshore balancing' strategy in the Persian Gulf, a strategy that they further theorized and presented as an alternative to 'liberal hegemony'. They explain that offshore balancing revolves around the maintenance of the US regional hegemony in the Western Hemisphere and the insurance of balance of power in key regions: Europe, Northeast Asia, and the Persian Gulf. This implies that the US would lead by example and rely on key regional allies to balance against any possible regional hegemon. If the balance of power is in peril, the US would intervene and reinstate the status quo. Practically, during the Cold War era, the US relied on two key 
regional allies — the Saudi kingdom and the Shah regime in Iran — to preserve its interests in the Middle East - a policy also known as 'Twin Pillars'. When the Islamic revolution occurred in Iran in 1979 and gave rise to the Islamic revolutionary regime of Ayatollah Khomeini, the Rapid Deployment Force was quickly forged by the Carter administration to prevent the subversion of the balance of power in the region by Iran or the Soviet Union. Yet American grand strategy during the post-Cold War period has remarkably changed. 'Offshore balancing' as a strategy in the Persian Gulf came to an end after the US intervention in Kuwait in 1991.

\subsubsection{Liberal Hegemony}

The deep entanglement of the US in the region was carried out under the Bush administration with its strategy of "regional transformation" in Iraq and Afghanistan following the 9/11 terrorist attacks (Mearsheimer \& Walt, 2016, p. 3; Walt, 2018). In the same vein, Stapleton (2016) is right to point out that the Bush administration adopted democratic peace theory. Indeed, that was also clearly pursued in the first term through President Bush's Freedom Agenda promoted in his National Security Strategy of 2002 (The White House, 2002a). In relation to unilateralism in American foreign policy, Schmidt and Williams (2008) stress that the neo-conservatives camp in the Bush administration advocated for the unilateral conduct of American foreign policy. They write: “The most striking example of the administration's willingness to proceed unilaterally, of course, was its decision to defy the will of much of the international community, including the UN Security Council, and invade Iraq” (p. 198).

For their part, Daalder and Lindsay (2003) argue that the Bush administration ushered in a revolution in American foreign policy and that this revolution was not "in 
America's goals abroad, but rather in how to achieve them" (p. 2). They write that President George W. Bush "relied on the unilateral exercise of American power rather than on international law and institutions to get his way" (p. 2), in addition to his keenness on regime change. In this respect, it should be mentioned that President Trump has frequently criticized the Bush administration's invasion of Iraq which, according to the president, cost the US trillions of dollars and thousands of deaths, in addition to the fact that it destabilized the Middle East. By way of example, candidate Trump said, in a speech on American foreign policy hosted by the National Interest in 2016:

It all began with the dangerous idea that we could make Western democracies out of countries that had no experience or interest in becoming a Western democracy. We tore up what institutions they had and then were surprised at what we unleashed. Civil war, religious fanaticism; thousands of American lives, and many trillions of dollars, were lost as a result. The vacuum was created that ISIS would fill. Iran, too, would rush in and fill the void, much to their unjust enrichment. Our foreign policy is a complete and total disaster. No vision, no purpose, no direction, no strategy (The National Interest, 2016).

\subsubsection{Retrenchment}

When it comes to retrenchment, the Obama strategy in the Middle East remains a matter of debate among scholars and academics. On the one hand, Yom (2020) underscores that the US undergoes a "Hegemonic Retreat" (p. 1) in the Middle East which he traces back to the Obama administration and attributes to the new structural dynamics in the region where a credible threat no longer exists. In other words, the Obama administration started the withdrawal from the region, and opted 
instead for a 'Pivot to Asia'. Brands (2018) corroborates the retrenchment strategy as well as the 'Asia Pivot' pursued in the Obama era and remarks that this was necessary as it "provided the country with a strategic breather after a period of overexertion" (p. 51) experienced under the Bush administration due to its overstretch in the Middle East.

On the other hand, in the eyes of Mearsheimer and Walt (2016), the Obama administration was no exception from the militarism and interventionism that marked the American foreign policy in the Middle East. It made the same mistakes with its intervention in Libya and entanglement in the civil war in Syria insisting that President Bashar al-Assad “must go" (p. 3). Along similar lines, Stapleton (2016) argues that the Obama administration did not renounce military approaches in pursuing its interests in the Middle East, as was evidenced in the US-led coalition against ISIS or the US bombardment of the Qaddafi forces in 2011. The administration simply shifted its tactics, that is abandoning full-scale dispatching of ground forces in the Middle East. Stapleton maintains that the Obama approach was characterized by its "light footprint" (p. 2) when conducting military actions. This includes the reinforcement of the capacities of the indigenous forces, such as the Iraqi army or the moderate Syrian rebels, the deployment of certain Special Operations Forces, and the reliance on US strike capabilities like the high frequency of drone attacks.

\subsection{Regional transformations in the Middle East before the Trump} administration

In what follows, I present some of the literature in relation to the changes that the Middle East has undergone prior to the Trump administration. This is very 
important to better understand how the Trump administration capitalized on the situation to push for more transformations in the region which would lay the ground for the security alignment between the Arab regimes and Israel in their pursuit of the shared interest in containing Iran, which eventually, suits US disengagement from the Middle East.

In an in-depth coverage entitled How The Israel-UAE Alliance Formalizes New Fault Lines in the Middle East, Odeh (2020) argues that the transformation that the Middle East is undergoing "was facilitated by the weakening of former giants in the region - Egypt, Iraq, and Syria - whose weakened states provided the opportunity for new rules and new alliances" (para. 6). Ferziger and Bahgat (2020) corroborate that "Since the early 2000s, the strategic landscape in the Middle East has profoundly changed" (p. 5). They attribute the decline of Egypt to the worsening economic conditions and the loss of its status as the leader of the Arab world. Regarding Iraq, they maintain that it was plagued by regional wars and the rise of ISIS. As for Syria, it was ravaged by the civil war that broke out in 2011 .

As corroborated by Dazi-Héni (2020), Ferziger and Bahgat (2020), and Totten (2016), there is much truth to Ryan's (2015) claim that the Middle East witnessed a number of "regional shocks" (para. 19), or what Al Ketbi (2020) calls "tectonic shifts" (p. 392), such as the Arab uprisings and the US rapprochement with Iran under the Obama administration. There is an increasing perception in the Middle Eastern states that the US is growing more and more reluctant with regard to its traditional and orthodox role as the guarantor of security and stability in the Middle East (Ferziger \& Bahgat, 2020; Ryan, 2015; Wechsler, 2019). Ferziger and Bahgat (2020) remark that the US has traditionally defended the Gulf states following the Carter 
Doctrine. They take President George H.W. Bush's intervention in Kuwait to liberate it from the Iraqi invasion as the best example to illustrate the US commitment to defend the GCC states. Yet things radically changed with President Bush's invasion of Iraq in 2003. For Ferziger and Bahgat, this "shifted the United States away from its traditional role as the most powerful defender of the regional status quo to the primary challenger of the existing state of affairs" (p. 6) which ironically resulted in the empowerment of Iran. Wechsler also argues along similar lines. Equally important, as far as the dwindling trust in the US is concerned, President Obama's rapprochement with Iran "set off alarm bells in the GCC states". President Obama went so far as to push Saudi Arabia to come to terms with the need to "share the Persian Gulf region with Iran" (p. 6). Due to this volatility in American foreign policy, the US "is largely seen as an unreliable partner who may be in the beginning stages of a strategic withdrawal from the region" (p. 7), Ferziger and Bahgat underscore. Allied with this view is that of Wechsler (2019) who posits that the US role in the Middle East has become a mere "Question of Will” (p. 25). In his words: "The questions being posed today are less about American capability than about American will, leading to deep uncertainty as to whether the United States still defines its regional interests as it once did". In brief, Wechsler stresses that "Many local leaders worried that this might mark a watershed in the path toward American strategic disengagement” (p. 29).

Some of the Obama-era policies in the region caused doubt in the views of critics as well as allies. The abandonment of Egypt's Mubarek by the Obama administration following the Arab uprisings in 2011 and the acceptance of the Muslim Brotherhood led some regimes in the Middle East to question the US support of its traditional allies in terms of their national security and the survival of their regimes 
(Quamar, 2018; Quero \& Dessì, 2019; Wechsler, 2019, p. 28). In brief, certain regimes were alarmed and concerned about the endorsement of democratization in the region by the Obama administration which would put their regime in peril, given their authoritarian nature. Moreover, Yarhi-Milo (2018) and Wechsler (2019, p. 28) argue that the US resolve was put into question by the inaction of the Obama administration against the $\mathrm{Al}$ Assad regime when it crossed Obama's 'red line' of using chemical weapons against its people. Yarhi-Milo writes: "If Obama had not intended to follow through on his threat, he should not have issued it in the first place" (p. 3). Therefore, this could seriously cast doubt on the US willingness to firmly and assertively protect its allies in the region, as affirmed by Al-Ubaydli (2016) and Freedman (2017), from the threat of Iran. Furthermore, Freedman (2017) underscores that the rapprochement of the Obama administration with Iran that culminated in the Iran Nuclear Deal led some of the regimes in the Middle East to doubt the US willingness to contain Iran's ambition to possess nuclear weapons and expand its influence in the region. $\mathrm{He}$ writes: “America's Middle Eastern allies, especially Saudi Arabia and Israel, were particularly concerned that another American 'red line', preventing Iran from acquiring a nuclear weapon, would also be crossed without any US response" (p. 244). Similarly, Al-Ubaydli (2016) raises an important question about the willingness of the Obama administration to attack Iran in case it closed the Strait of Hormuz after it stepped back from its military actions against the Assad regime following its resort to chemical weapons. He posits that the regional powers were doubtful about the "US' commitment to deploying the Fifth Fleet to protect the Strait of Hormuz" given "the US' diminishing military activism in the Middle East" (para. 6). 
When it comes to the formation of a coalition that counters Iran's influence in the Middle East, Totten (2016) points out that there is a rapprochement between some Arab states and Israel in the making which could result in the formation of an Arab Sunni-Israeli alliance whose main objective is to confront Iran's influence in the region. In his words:

The effect of all this is something no one would have predicted a couple of decades ago and only the most astute predicted even a couple of years agothe Sunni Arab world, unofficially led by Saudi Arabia, is quietly forging a de facto alliance with Israel against Iran. (p. 29)

In the same vein, following the meeting between Saudi Prince Turki al-Faisal, former intelligence chief, and Israeli Major General Yaakov Amidror, former national security advisor, organized by The Washington Institute for Near East Policy on May 6, 2016, the Lebanese daily newspaper Assafir described the meeting as evidence that Saudi Arabia has shifted its stance towards Israel and that it is now exploring the formation of an Arab-Israeli alliance that would secure the rule of the Al Saud family, as well as the stability of the GCC states, and fill the void of the US "withdrawal" (p. 2) from the region (as cited by Abdelaziz, 2016).

Similarly, Maher (2020) claims that the growing influence of Iran and its proxies, coupled with its nuclear ambitions, has reinforced Israel's sense of security and pushed it to look for alternative forms of deterrence. Hence, a rapprochement with the Arab states has become part of Israel's new "overall deterrence strategy" (p. 17). Azodi (2020) posits that: "The emerging alliance has a strong potential to shift the regional balance of power in favor of Iran's adversaries, namely Saudi Arabia and Israel, which in turn, could increase Tehran's sense of insecurity" (p. 6). 


\section{Chapter Three: Methodology}

\subsection{Data collection}

Data for this empirical research comprised a corpus representative of different genres of documents about the Trump-era American foreign policy in the Middle East. The corpus was retrieved from the official documents published by the Trump administration during its mandate with respect to Iran and the Israeli-Palestinian conflict. This research thesis views the policies towards Iran's influence in the Middle East and the Israeli-Palestinian conflict as two important parameters in deepening one's understanding of the Trump-era American foreign policy and its geopolitical implications in the region. Through these two parameters, data sets were identified and interpreted.

The data source was primary and consisted of electronic textual documents published by the Trump administration. The corpus contained policy documents such as the "Maximum Pressure" campaign or President Trump's "Peace to Prosperity" plan. The latter was designed by a team led by President Trump's son-in-law and former Senior Foreign Policy Advisor Jared Kushner. The team included Jason Greenblatt, former Special Representative for International Negotiations, Avi Berkowitz, former Assistant to the President and Special Representative for International Negotiations, and Brian Hook, former U.S. Special Representative for Iran and Senior Adviser to the US Secretary of State, to name a few. The corpus also included agreements such as the Abraham Accords Declaration and the treaties of peace between Israel and the Arab states with which it normalized ties. Equally important, it encompassed everything publicly published by the Trump White House and available in the 'foreign policy' section on its website archives from statements 
and releases, fact sheets, proclamations, to joint remarks, press briefings, op-eds, etc. All these documents were carefully vetted as they were extracted from the official US administration website, hence they can be considered as authentic and reliable sources.

Regarding sample framing, inclusionary criteria included American foreign policy documents in the Middle East under the Trump administration. Data in this research were approached in a systematic manner. Preliminary research was carried out and a total of 426 public documents derived from the White House website archives were collected. After an in-depth review, exclusionary criteria were applied. Only documents that were relevant to Iran and the Israeli-Palestinian conflict were identified as the sample. The ones related, for instance, to state and non-state actors in questions other than Iran and the Israeli-Palestinian conflict, were not directly relevant to this research and were therefore excluded from the data sample. By way of example, statements on the passing of Sultan Qaboos bin Said Al Said of Oman or the First Lady Melania Trump's meeting with Queen Rania of Jordan were eliminated. This rendered the new sample size 390. The rationale behind applying such exclusionary criteria was the magnitude of documents related to the Middle East and the relevance of data to the research questions.

The time frame of the sample was from January 2017 to January 2021. This period represented the Trump presidency and was of utmost importance and relevance to the research topic as it covered the policies pursued by the Trump administration in the region. President Trump's pledges or promises as a presidential candidate exceeded the scope of this thesis; therefore, President Trump's tenure constituted a convenient time frame to answer my research questions. 


\subsection{Data analysis}

Qualitative content analysis of the data gathered for this research was conducted using an interpretive approach. Given that my corpus consisted of multiple sorts of data, analysis of the findings hoped to develop a deeper understanding and greater knowledge of the strategic shift that marked the American foreign policy in the Middle East and its implications on the regional geopolitical map.

\subsubsection{The classification scheme}

In this thesis, my corpus was coded using a qualitative analysis software called 'Quirkos'. Similar to 'ATLAS.ti' and 'NVivo', the software helped me to manually code the data in a practical and effective manner. Its lively and interactive interface represented the corpus findings in a visual way that helped detect the empirical evidence that addressed my research questions. I strived to make this research consistent and reliable by setting clear and well-defined coding and category rules. To start with, the basic units applied for text coding were the 'sentence' and 'paragraph'. Codes in this corpus were developed following a deductive approach. In this regard, Frey (2018) writes that "the researcher may begin with a collection of initial codes derived from the keywords used in the literature search and the knowledge gained in conducting the literature review for the study (p. 5). Accordingly, I placed a set of initial codes that were extracted from my preliminary research of data collection and that were reflective of the research questions as well as the objectives of this thesis. These initial codes consisted of predetermined labels that were initially applied to a subsample, a pilot study, and subsequently to the entire corpus. Codes were initially elaborated as follows: 
- Regarding Iran: Iran and its proxies as the common threat, a catastrophic Iran Nuclear Deal, rebuilding mutual trust, rallying partners, multilateralism vs. unilateralism, etc.

- Regarding the Israeli-Palestinian conflict: A rupture with the previous approaches, the need for a new realistic approach, multilateralism vs. unilateralism, bridging the gap between the Arab states and Israel, ending the chronic conflict, etc.

- Regarding the geopolitical implications: regional transformation, countering Iran and its proxies, collective security and regional peace, economic prosperity, etc.

At this juncture of the pilot study, codes were tested on a subsample of documents. Frey (2018) suggests that a "diverse subsample of documents (6-12)" from the whole corpus is sufficient for code testing. For this research, I selected a subsample of 40 documents. They were obtained based on 4 'critical incidents'; each incident followed by 9 consecutive documents. This implied that each parameter assigned 2 incidents. The 'critical incidents' were identified according to certain important events related to the Trump administration's policies towards the Iranian and the Israeli-Palestinian questions. In developing the 'Critical Incident Technique' as a separate research methodology, Flanagan (1954) posits that critical incidents should have effects on the issue under examination and are determined based on the judgment of the observer. He writes: "To be critical, an incident must occur in a situation where the purpose or intent of the act seems fairly clear to the observer and where its consequences are sufficiently definite to leave little doubt concerning its effects" (p. 1). Drawing on this definition, I set two objective criteria that helped me 
identify the 4 critical incidents for the pilot study. The first criterion concerned the importance of a decision regarding the Trump-era foreign policies towards Iran and the Israeli-Palestinian questions. For instance, this could be an announcement, signature, or withdrawal from an agreement. The second criterion was about the effects or impact of a decision, be they negative or positive, on the respective parameter. For example, a decision could spur an array of domestic and international support or opposition and criticism.

Regarding Iran, a 'critical incident' in the Trump-era foreign policies was the announcement of the Trump administration's new strategy on Iran on October 13, 2017. This strategy signaled a new approach advocated by the Trump administration to contain Iran's influence in the region; therefore, it was worth the selection. Accordingly, 10 documents were extracted starting from the announcement of the strategy. Likewise, the withdrawal of the US from the Iran Nuclear Deal on May 8, 2018, constituted another crucial decision by Trump's administration in its strategy towards Iran. Indeed, the unilateral withdrawal from the Iran deal represented a tipping point in addressing Iran's nuclear program, and thus it was worth choosing it as a critical incident. Therefore, 10 documents were selected starting from the pull-out from the deal.

With regard to the Israeli-Palestinian conflict, two critical incidents in the Trump administration's strategy were identified to select the remaining 20 subsamples. The first one was the announcement of the "Peace to Prosperity" plan on January 28, 2020. This represented a crucial event in that it laid out President Trump's vision on how to end the Israeli-Palestinian conflict and create stability in the Middle East. Likewise, another critical incident for this research was the announcement of the 
normalization of ties between Israel and UAE on August 12, 2020. The event was a breakthrough in the Arab-Israeli relations as it rejuvenated the normalization track with Israel, after 26 years since the signature of the last peace deal between Israel and Jordan. In light of these two critical incidents regarding the Trump administration's policies towards the Israeli-Palestinian conflict, 10 documents were selected for each critical incident.

The initial findings of the pilot study revealed that the pre-set codes that were suggested following my preliminary research were strongly identifiable within the subsample corpus. Results showed that 7 of my the pre-determined codes were the highest and most dominant nodes in the corpus under study: 'A catastrophic Iran Nuclear Deal' (219), 'Ending the chronic conflict' (188), 'Bridging the gap between the Arab states and Israel' (151), 'The need for a new realistic approach' (126), 'Regional Transformation' (121), 'Iran and its proxies as the common threat' (93), and 'Countering Iran and its proxies' (84). This suggested that the 40 subsamples, that were selected based on the 4 critical incidents, were to a great extent illustrative of the accuracy, validity, and reliability of my pre-set codes. The preliminary results seemed to support the thesis statement underpinning this study: the American foreign policy in the Middle East undertook a strategic shift under the Trump administration. This shift was premised on the US policies towards Iran and the Israeli-Palestinian conflict. By doing so, and as the US recalibrates its engagement in the region, the Trump administration triggered a geopolitical transformation through an GCC-Israeli security alignment to better curb the Iranian threat in the long run.

After the codes had been properly tested on the sum of the subsamples identified for the pilot study, they were applied again to the entire corpus of 
documents. Based on the codes pinpointed, I set a group of categories/themes that guided me through the interpretation of the findings. They were as follows:

(1) The adoption of a "Maximum Pressure" campaign towards Iran

(2) The adoption of a top-down approach regarding the Israeli-Palestinian conflict, President Trump's "Peace to Prosperity" plan

(3) Triggering geopolitical transformation to confront Iran's quest for regional hegemony

\subsubsection{Ryan's 'regime change' theoretical framework}

In the interpretation phase, based on document-based proof and evidence, I examine the strategic shift in the Trump-era American foreign policy in the Iranian and Israeli-Palestinian questions. Then, I explore insights into the implications of this shift on the geopolitical landscape and security alignment in the region. In this context, I suggest Ryan’s (2009, 2015) ‘regime security’ approach as an insightful theoretical framework that could help analyze how the Trump administration affected a geopolitical transformation by moving the Arab states closer to Israel, hence ushering a new geopolitical setting that favors US disengagement from the region and that contains Iran's growing influence.

Ryan (2015) underscores that the regional system in the Middle East was subject to a plethora of "regional shocks" (para. 19) among which were: the Arab uprisings, the collapse of certain regimes, the ongoing civil wars in Syria, Yemen, and Libya, and the Iran Nuclear Deal. For Ryan, these "major jolts" (para. 1) destabilized the regional system and triggered regimes in the region to take actions both domestically and externally to maintain their security. Interestingly, these events "have shaken the system of regional alliances and alignments" (para. 1), which, as I 
argue, represented an opportunity for the Trump administration to tailor its foreign policies towards the Middle East. Accordingly, it altered the geopolitical landscape and made new alignment choices possible and appealing to both the Arab regimes and Israel. Ryan (2015) argues that regime security is the primary driver of alliance politics in the region, particularly at the level of inter-Arab relations. He lays great emphasis on the regime's domestic and external threats that lead its leaders to reconsider alliance choices in the Middle East. In other words, regime insecurity for the Arab rulers emanates from both their internal and external security dilemmas. The Arab regimes are always obsessed with their survival, thus their perception of threats invariably pushes them to shift policies both internally and externally.

It is in this context that, in reference to his research in 1995, Ryan argues that "a regime security approach, rather than a Neorealist framework, better explained Arab foreign policies and alliance choices" (para. 6). Ryan (2009, 2015, p. 7) slightly refutes the macro- and system-level analyses of the Neorealist school in relation to alliance and alignment formation in the Middle East. According to him, the Neorealists do not provide sufficient empirical evidence that supports such theories when applied to the region's alignments. For instance, drawing on Carlos Escude's (1993) critique of Neorealism in 'International Relations Theory: A Peripheral Perspective', Ryan remarks that Kenneth Waltz's (1979) balance of power theory draws heavily on Western-centric empirical grounds which are largely inapplicable to the Middle Eastern realm. This inapplicability is due to the specificities of the Western system of states. The latter is different from the Arab state system in terms of certain notions such as the balance of power, alliances, and national security. Similarly, in reference to 'The Origins of Alliances', Ryan (2009, 2015, p. 7) 
acknowledges that Stephen M. Walt (1987) contributes immensely to the literature of Neorealism and alliance formation by enlarging the empirical study to encompass the Middle East setting. Yet he points out that Walt largely underestimated the inter-Arab dynamics in terms of the importance of domestic politics, ideology, and political economy. He argues that Walt's assumption of external security threat is too deterministic while, empirically, alignments in the Middle East tell a different story. In brief, Ryan maintains that the Neorealist views on alliance overlook the importance of domestic political constraints by narrowing the scope of what constitutes a threat; they eliminate non-military variables and stick to security threats as an external factor. Equally important, most inter-Arab alignments may not even fit into the nature of formal alliances as they might not entail "mutual defense pacts". Therefore, Ryan concludes that the Neorealist theories such as the balance of power and balance of threat do not necessarily apply to inter-Arab politics. From another perspective, Ryan relatively agrees with Steven R. David's (1991) theory of 'Omnibalancing'. The latter is a reviewed version of balance of power theory and stresses the importance of internal and external security threats behind alignment politics in the Third World. Yet while he valorizes that 'Omnibalancing' takes into account domestic threats, Ryan argues that the theory essentially addresses asymmetrical alignments; that is alignments between Third World states and the superpowers.

Drawing on his extensive empirical work on Jordan as a case study, Ryan (2009) finds that alignment choices in the Middle East were driven by three major variables. The first variable is 'external security'; it includes external threats of all sorts. The second one is 'domestic security' which includes local opposition, social discontent, domestic uprisings, etc. The third variable is 'political economy' which 
entails the need for economic partnerships and foreign aid, etc. These key determinants, according to Ryan, are the driving engine of alignment politics in the Arab world. He argues that they do not necessarily need to be all affected so that the regime resorts to alignment. The most critical factor could direct the alignment choices of the regime rulers. "Hence at times alignment decisions will be motivated primarily by traditional security concerns. At others, the most pressing need may be for economic support" (p. 14). Driven by these variables, regimes in the Arab world choose either domestic or external alignments to ensure their survival.

Based on Ryan's three variables, and given that many of the Arab regimes are “security-obsessive” (p. 11), I suggest that his 'security regime' approach offers an interesting theoretical framework on how the Trump administration affected a geopolitical transformation in the region. Ryan's theory seems relevant given that the Arab-Israeli alignment was triggered by the Trump administration which brokered the normalization of ties between the four Arab states and Israel. In other words, the Trump administration tapped into Ryan's variables to push the Arab regimes for a security alignment with Israel. In a nutshell, in my discussion of the geopolitical implications of the strategic shift of the Trump-era foreign policies, I attempt to test the applicability of Ryan's 'regime security' theory on the Trump administration's approaches to the Iranian and Israeli-Palestinian conflict. 


\section{Chapter Four: Results}

This empirical research systematically analyzed a corpus of 390 documents revolving around the American foreign policy towards Iran and the Israeli-Palestinian conflict under the Trump administration. In this chapter, I present in detail the final findings of my research and provide evidence that supports them. Only important and relevant findings related to my research questions are conveyed. Other results, such as President Trump's “Economic Plan” for Palestine, US bilateral relations with Middle Eastern states, and fighting ISIS were also anticipated, yet they were not addressed due to their irrelevance to the questions under investigation. As previously explained, after coding the entire corpus, 3 major categories/themes emerged. Accordingly, I display the results in a graph as appeared in the content analysis software (Figure 1). Further, I synthesize the findings in a table for a better understanding of the categorization of data (Table 1). Then, I support the findings with details from the corpus to demonstrate how the codes and categories address my research questions. 
Figure 1: Final results of the corpus as shown in the content analysis software (Quirkos)

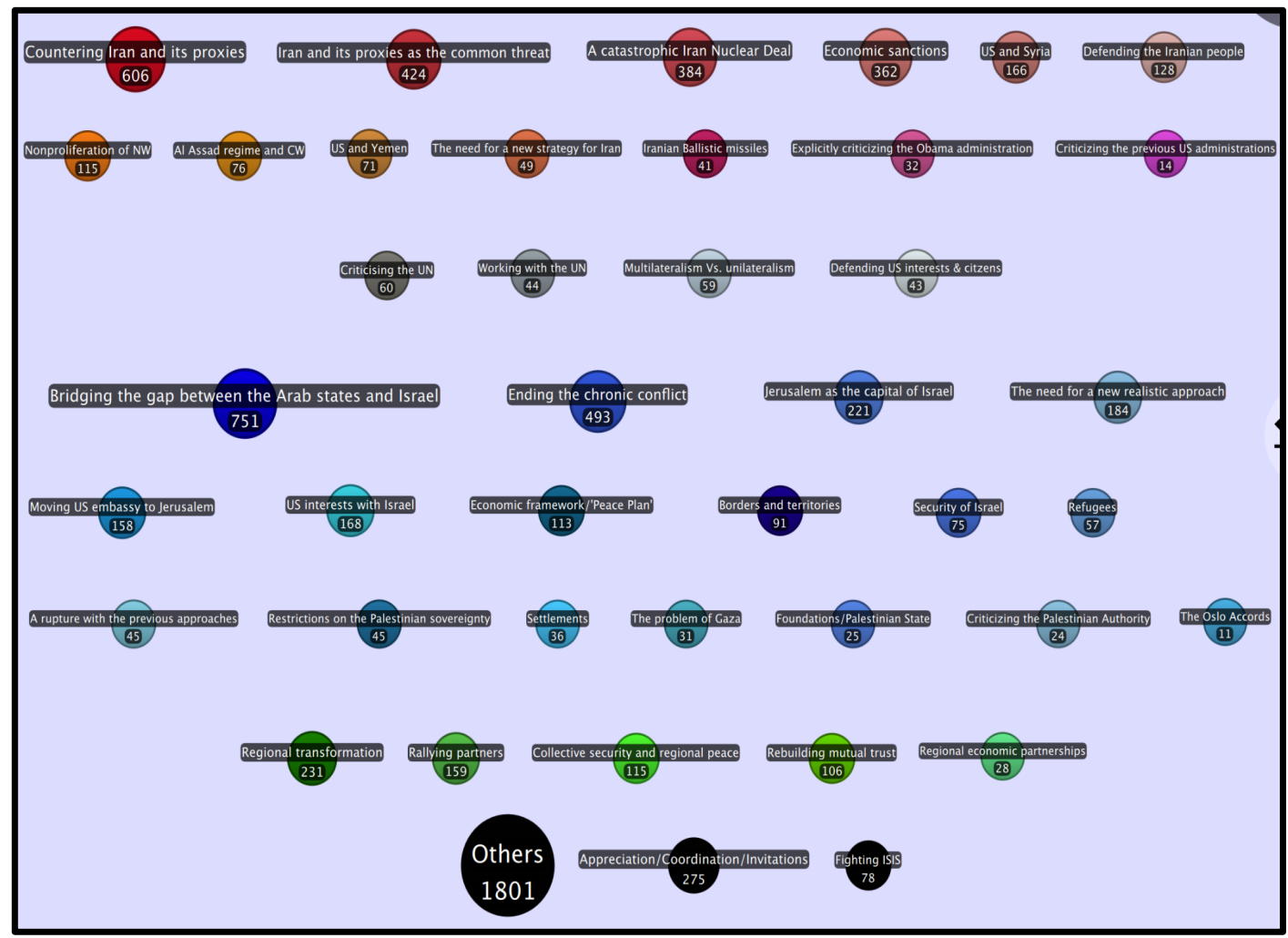

Table 1: Synthesized findings of the corpus after the content analysis on Quirkos

\begin{tabular}{|c|c|c|}
\hline Category & Code & Synthesized finding \\
\hline \multirow{6}{*}{$\begin{array}{l}\text { The adoption of a } \\
\text { "Maximum Pressure" } \\
\text { campaign towards Iran }\end{array}$} & $\begin{array}{l}\text { Iran and its proxies as the common } \\
\text { threat }\end{array}$ & \multirow{6}{*}{$\begin{array}{l}\text { The Trump administration } \\
\text { portrayed Iran and its clients } \\
\text { as the common threat to the } \\
\text { US, Arab states, and Israel. It } \\
\text { unapologetically abandoned } \\
\text { the previous US approaches } \\
\text { towards Iran, especially the } \\
\text { rapprochement of the Obama } \\
\text { administration, and instead, } \\
\text { pursued a confrontational } \\
\text { strategy of "Maximum } \\
\text { Pressure" to confront Iran's } \\
\text { alleged destabilizing activities } \\
\text { in the Middle East. The new } \\
\text { strategy espoused both } \\
\text { multilateralism and } \\
\text { unilateralism. }\end{array}$} \\
\hline & A catastrophic Iran Nuclear Deal & \\
\hline & $\begin{array}{l}\text { Explicitly criticizing the Obama } \\
\text { administration }\end{array}$ & \\
\hline & $\begin{array}{l}\text { Criticizing the previous } \\
\text { administrations }\end{array}$ & \\
\hline & Countering Iran and its proxies & \\
\hline & $\begin{array}{l}\text { A mixture of multilateralism and } \\
\text { unilateralism }\end{array}$ & \\
\hline $\begin{array}{l}\text { The adoption of a top- } \\
\text { down approach }\end{array}$ & $\begin{array}{l}\text { A rupture with the previous } \\
\text { approach }\end{array}$ & $\begin{array}{l}\text { The Trump administration } \\
\text { firmly renounced the previous }\end{array}$ \\
\hline
\end{tabular}




\begin{tabular}{|c|c|c|}
\hline \multirow{6}{*}{$\begin{array}{l}\text { regarding the Israeli- } \\
\text { Palestinian conflict, } \\
\text { President Trump's } \\
\text { "Peace to Prosperity" } \\
\text { plan }\end{array}$} & $\begin{array}{l}\text { The need for a new realistic } \\
\text { approach }\end{array}$ & \multirow{6}{*}{$\begin{array}{l}\text { peace initiatives to resolve the } \\
\text { Israeli-Palestinian conflict, } \\
\text { and, instead, pursued a new } \\
\text { realistic and pragmatic } \\
\text { approach that was embodied in } \\
\text { the "Peace to Prosperity" plan. } \\
\text { The Trump administration's } \\
\text { vision followed a top-down } \\
\text { "outside-in" approach to the } \\
\text { conflict by focusing on } \\
\text { bridging the gap between the } \\
\text { Arab states and Israel since it } \\
\text { suggested a plan that required } \\
\text { unimaginable concessions } \\
\text { from the Palestinians. } \\
\text { President Trump's "Peace } \\
\text { plan" espoused both } \\
\text { multilateralism and } \\
\text { unilateralism that was often } \\
\text { inconsistent with international } \\
\text { consensus. }\end{array}$} \\
\hline & $\begin{array}{l}\text { Bridging the gap between the Arab } \\
\text { states and Israel (A top- } \\
\text { down/“outside-in" approach) }\end{array}$ & \\
\hline & $\begin{array}{l}\text { Triggering a change in perception: } \\
\text { sharing common challenges and } \\
\text { interests }\end{array}$ & \\
\hline & $\begin{array}{l}\text { Economic and security } \\
\text { motives/incentives behind the } \\
\text { normalization of relations between } \\
\text { the Arab states and Israel }\end{array}$ & \\
\hline & Ending the conflict & \\
\hline & $\begin{array}{l}\text { A mixture of multilateralism and } \\
\text { unilateralism }\end{array}$ & \\
\hline \multirow{3}{*}{$\begin{array}{l}\text { Triggering geopolitical } \\
\text { transformation to } \\
\text { confront Iran's quest } \\
\text { for regional hegemony }\end{array}$} & Rebuilding trust & \multirow{3}{*}{$\begin{array}{l}\text { The American foreign policy } \\
\text { under the Trump } \\
\text { administration sought to } \\
\text { engender a geopolitical } \\
\text { transformation in the Middle } \\
\text { East. To achieve its aim, it } \\
\text { consistently worked on } \\
\text { rebuilding trust with US allies, } \\
\text { rallying up its partners, and } \\
\text { creating a new geopolitical } \\
\text { landscape. In other words, the } \\
\text { Trump administration } \\
\text { attempted to activate alliance } \\
\text { politics by aligning the Arab } \\
\text { states and Israel to balance } \\
\text { against Iran and its proxies in } \\
\text { the region. }\end{array}$} \\
\hline & Rallying partners & \\
\hline & Creating a geopolitical shift & \\
\hline
\end{tabular}

In analyzing the corpus, findings revealed that data from the different types of documents affirmed and fell in line with each other. Results were neither inconsistent nor contradictory. On the contrary, they were consistent and indicative that the Trump administration embarked on a strategic shift in the American foreign policy in the 
Middle East. This shift aimed to engender a novel geopolitical setting, based on a GCC-Israeli security alignment, that balances against Iran's alleged aggression and that favors US disengagement from the region.

\subsection{The adoption of a "Maximum Pressure" campaign towards Iran}

\subsubsection{Iran and its proxies as the common threat}

Repeatedly evident within the corpus is how the Trump administration perceived Iran as the greatest danger to US interests and allies. Throughout the corpus, the Trump administration endlessly portrayed the Iranian regime and its clients as the common threat, one that was behind all the mayhem that plagued the Middle East. For the Trump administration, the Iranian regime and its aligned groups represented the main source of instability in an already turbulent region. In his address to the Arab Islamic American Summit on May 21, 2017, President Trump depicted Iran as the common menace to the region. He said:

But no discussion of stamping out this threat would be complete without mentioning the government that gives terrorists all three - safe harbor, financial backing, and the social standing needed for recruitment. It is a regime that is responsible for so much instability in the region. I am speaking of course of Iran. From Lebanon to Iraq to Yemen, Iran funds, arms, and trains terrorists, militias, and other extremist groups that spread destruction and chaos across the region.

In the "Peace to Prosperity" plan revealed in January 2020, the Trump administration alerted the states in the Middle East to the geopolitical threat posed by Iran. The plan stated that: "Iran's strategy seeks to encircle Israel, using Lebanon, Syria and Gaza, and encircle the Kingdom of Saudi Arabia Iraq, Bahrain and Yemen” 
and that "Iran hopes to establish a "land bridge" that stretches from the Iran-Iraq border to the Mediterranean Sea".

\subsubsection{A catastrophic Iran Nuclear Deal}

Bashing the Joint Comprehensive Plan of Action was a prominent theme in this research corpus. For the Trump administration, the Iran Nuclear Deal failed spectacularly to address other aspects of Iran's destabilizing behavior in the region. It was marred by a plethora of flaws and regarded as none other than a colossal mistake. Throughout the corpus, the JCPOA drew a storm of criticism not only from the President and his cabinet but also from the US Representatives, Senators, foreign leaders from the Middle East, journalists, and think tanks. The JCPOA was interchangeably referred to as “Obama's dangerous Iran Nuclear Deal”, a “one-sided deal that should have never, ever been made", "nothing short of a foreign policy debacle", etc. It took the Trump administration less than a month to publish a joint readout of the President's meeting with Israeli PM Netanyahu in which it stated that "the two leaders agreed that the Iran nuclear deal was a terrible deal for the United States, Israel, and the world".

Dissatisfied with the JCPOA, President Trump, on October 13th, 2017, announced a new strategy on Iran. It decided to decertify that Iran was abiding by the terms of the JCPOA. 8 May 2018 marked the US withdrawal from the JCPOA. Particularly noticeable in the corpus was the fact that not only the Trump administration and American decision-makers that commended the US withdrawal from it, the views of certain leaders in the Middle East also corroborated that the deal was not in the best interest of the US and the region. PM Netanyahu lauded the President's "bold decision" to pull out from the deal. Similarly, the Kingdom of Saudi 
Arabia's Ambassador to the United States Khalid bin Salman said that his country "fully support[ed] the measures" taken by President Trump. In the same vein, Anwar bin Mohammed Gargash, the Former Minister of State for Foreign Affairs affirmed that the JCPOA was "a flawed deal" and that the decision of the President was "the correct one".

\subsubsection{Explicitly criticizing the Obama administration}

Throughout its mandate, the Trump administration poured harsh criticism on the Obama administration, by directly blaming it, for its alleged poor handling of Iran's growing influence in the Middle East. Results showed that the Trump administration's discontent with the Obama administration was not only for its rapprochement with Iran but also for its shaky and volatile policies towards the regime of Bashar Al Assad, Iraq, and ISIS. With regard to Iran, in a fact sheet issued on October 13th, 2017, the Trump administration criticized the shortsightedness of the Obama administration for not addressing the different threats that Iran poses to US interests and allies. It slammed the previous administration's “myopic focus on Iran's nuclear program to the exclusion of the regime's many other malign activities" that destabilized the region. Regarding Syria, for instance, President Trump exposed the Obama administration's lack of resolve to punish the Al Assad regime for its alleged use of chemical weapons against its people. When asked by a journalist, in April 2017, in a joint conference with King Abdullah II of Jordan, whether his administration blamed the Obama administration for setting a red line to the Al Assad regime and not following through, President Trump confirmed the question and replied as follows: 
"Well, I think the Obama administration had a great opportunity to solve this crisis a long time ago when he said the red line in the sand. And when he didn't cross that line after making the threat, I think that set us back a long ways, not only in Syria, but in many other parts of the world, because it was a blank threat. I think it was something that was not one of our better days as a country. So I do feel that, Julie. I feel it very strongly”.

On October 30, 2020, a statement was published saying that: “On issue after issue, President Trump reversed the disastrous foreign policy of the Obama Administration and put the American people first".

\subsubsection{Criticizing the previous administrations}

As far as the US entanglement in the Middle East is concerned, it was noticeable that President Trump unequivocally expressed his disapproval of his predecessors' policies which, according to him, only further destabilized the region. On April 5, 2017, in a joint press conference with King Abdullah II of Jordan, President Trump commented on the US intervention in the region:

And so, as you know, I would love to have never been in the Middle East. I would love to have never seen that whole big situation start. But once it started, we got out the wrong way, and ISIS formed in the vacuum, and lots of bad things happened.

He also added:

And I have to just say that the world is a mess. I inherited a mess. Whether it's the Middle East, whether it's North Korea, whether it's so many other things, whether it's in our country — horrible trade deals — I inherited a mess. We're going to fix it. We're going to fix it". 
In the same respect, Newt Gingrich, in an op-ed, entitled 'The President Just Made A Titanic Foreign Policy Shift'. The Media Missed It', written for the Washington Post and shared by the Trump administration on May 25, 2017, confirmed that the President's speech in the Arab Islamic American Summit on May 21, 2017 "implicitly repudiated the approaches of his two immediate predecessors" in the region's most pressing issues.

\subsubsection{Countering Iran and its proxies}

\subsubsection{The need to counter Iran's destabilizing behavior}

Throughout the corpus, it was abundantly clear that countering Iran's activities and proxies in the region was a foreign policy priority for the Trump administration. According to a public statement published on January 22, 2017, President Trump's first call with PM Netanyahu after taking office stressed that both "agreed to continue to closely consult on a range of regional issues, including addressing the threats posed by Iran”. Following President Trump's meeting with Deputy Crown Prince and Minister of Defense of the Kingdom of Saudi Arabia Mohammed bin Salman Abdulaziz Al Saud, on March 15, 2017, both stressed "the importance of confronting Iran's destabilizing regional activities". As an example of the need to confront Iran's proxies, the Trump administration, in a public statement published on October 10, 2017, entitled 'It's Time to Mobilize a Global Response to the Terrorist Group Lebanese Hizballah', urged the US partners to work more on containing the group's actions.

\subsubsection{President Trump's New Strategy on Iran}

According to the Trump administration, the JCPOA was flawed because it did not tackle the entirety of Iran's alleged malign behavior in the Middle East and the 
world. Therefore, “The Trump Administration's Iran policy will address the totality of these threats from and malign activities by the Government of Iran". President Trump's new strategy was inspired by the "peace through strength" previously pursued by President Reagan and rejected rapprochement with Iran as the President "understands the dangers of appeasement".

The new strategy, issued on October 13, 2017, enumerated different objectives to confront Iran's behavior in the regions. First, it aimed at reviving regional alliances and traditional partnerships to swing the balance against Iran. Second, it aimed at denying the Iranian regime the financial wherewithal to fund terrorist activities and proxies, in particular through the Islamic Revolutionary Guard Corps (IRGC). The third objective was to protect against and confront the threats of ICBM missiles to the US and its allies in the region. Fourth, the strategy aimed at mobilizing the international community to condemn the Iranian regime's infringement on human rights including the unjust imprisonment of the US and foreign citizens. Fifth, and the most important objective, the strategy aimed at preventing Iran from acquiring nuclear weapons. The "Peace to Prosperity" plan also pointed to the importance of collectively countering the Iranian threat in the Middle East. For instance, the plan urged the states in the region to "work together, along with the United States, to protect the freedom of navigation through international straits that were increasingly subject to the threat of Iran, its proxy forces, and terrorist groups".

In his second address to the UNGA on September 25, 2018, President Trump praised his administration's "bold diplomacy" in mitigating the threats posed by the Iranian regimes, among many other threats worldwide. Yet it seemed that the US was willing to take military actions when it perceived a threat to its national security was 
"imminent". That was the case with the killing of Major-General Qassem Soleimani, head of the elite Quds Force, and the Iraqi militia commander Abu Mahdi alMuhandis on January 3, 2020.

\subsubsection{Economic sanctions}

Throughout the corpus, the reimposition of sanctions on the Iranian regime along with its clients in the Middle East was a primary pillar that undergirded the Trump administration's new campaign of "Maximum Pressure". Notwithstanding the magnitude of sanctions that targeted the Iranian regime, results showed that US sanctions were unilaterally asserted on Iran without the support of the EU nor the UN. By November 5, 2018, all sanctions lifted under the JCPOA were fully reimposed by the US, following its withdrawal from the deal in May 2018. Sanctions targeted, among other sectors, banking, commerce, industry, energy, oil, and gas sectors in Iran.

\subsubsection{A mixture of multilateralism and unilateralism}

Data showed that the US, in addressing Iran's alleged malign activity in the region, acted both multilaterally and unilaterally. What was noticeable is that the US preferred to contain Iran and its clients outside the auspices of the United Nations. Regarding multilateralism, the Trump administration, in its endeavor to overcome what was regarded as a "disastrous" JCPOA, called exclusively the European allies for the creation of a more holistic additional agreement that curbs Iran's behavior. By the same token, in a press briefing on January 12, 2018, a senior administration official stated that: "I do want to stress also that this would not entail direct negotiations with the Iranians, this would be something the United States works out with our European partners only". Interestingly, multilateralism did not convince the 
EU of the "Maximum Pressure" campaign which was eventually endorsed mostly by Middle Eastern allies with whom the Trump administration closely consulted on the Iranian containment throughout its tenure.

As far as unilateralism was concerned, the Trump administration unilaterally recognized the Israeli sovereignty over the Golan Heights, Syrian territories captured by Israel in the 1967 June War. In a proclamation of the decision issued on March 25, 2019, President Trump maintained that the territories have been historically used by Iran and its clients in the region, such as Hizballah, to launch deadly assaults on Israel. Therefore, it was "appropriate" for the US to recognize the territories as part of Israeli sovereignty. In defending the US right to protect itself and pursue its interests, President Trump frequently promoted the embrace of sovereignty. For instance, in a fact sheet issued on September 24, 2019, the Trump administration put emphasis on the importance of respecting American sovereignty. It said: "President Donald J. Trump has shown that the path to prosperity and strength lies in lifting up our people and respecting our sovereignty". While the Trump administration was willing to multilaterally forge an alternative Iran Nuclear Deal with the US partners, albeit outside the auspices of the UN, the situation was totally different with Syria. Findings showed that the Trump administration tried to reach a political solution to the Syrian conflict through the United Nations Security Council. For instance, it always emphasized the importance of the UNSCR 2254 and the United Nations-led Geneva Process which urged a ceasefire and a peaceful settlement of the Syrian civil war. 


\subsection{The adoption of a top-down approach regarding the Israeli-Palestinian conflict, President Trump's “Peace to Prosperity" plan}

\subsubsection{A rupture with the previous approach}

Results demonstrated that the Trump administration was assertive in rejecting what was considered archaic strategies to the Israeli-Palestinian conflict that proved to be unproductive and fruitless. In a statement issued on December 6, 2017, on the recognition of Jerusalem as the capital of Israel, President Trump indicated that his administration will abandon the unsuccessful policies of the past to avoid the historic deadlock in the Israel-Palestinian conflict. He stressed: "We cannot solve our problems by making the same failed assumptions and repeating the same failed strategies of the past". In the official signing ceremony for the peace agreements between Israel and Arab states on September 15, 2020, President Trump reiterated that: "These agreements prove that the nations of the region are breaking free from the failed approaches of the past". In short, the Trump administration was unequivocal in abandoning the previous stances towards the conflict.

\subsubsection{The need for a new realistic approach}

Results showed that after renouncing the previous approaches to the IsraeliPalestinian conflict, the Trump administration advocated instead for the embrace of a novel "realistic "approach that can potentially solve the chronic conflict. This new approach was driven by pragmatic outcomes. In his address to the Arab Islamic American Summit on May 21, 2017, President Trump declared that his administration is "adopting a Principled Realism, rooted in common values and shared interests". On September 20, 2017, in his address to the 72nd United Nations General Assembly, President Trump emphasized that his administration was "guided by outcomes, not 
ideology". The "Peace to Prosperity" plan put emphasis on the importance of a realistic solution to the long-standing conflict driven by pragmatic principles. For Trump's "Vision", "A realistic solution would give the Palestinians all the power to govern themselves but not the powers to threaten Israel". On October 23, 2020, in his remarks about the announcement of the normalization of ties between Israel and Sudan, President Trump commented that: "We did it the opposite way — exactly the opposite way". In a nutshell, the Trump administration pursued a remarkably different approach from its predecessors.

\subsubsection{Bridging the gap between the Arab states and Israel}

Pertinent to the adoption of a new realistic approach, was how the Trump administration consistently worked on bridging the gap between the Arab states and Israel. This endeavor was noticeably persistent throughout the Trump era indicating that the administration pursued a top-down "outside-in" approach to the IsraeliPalestinian conflict. On February 15, 2017, less than a month after the administration started its mandate, and during a joint press conference with President Trump, PM Netanyahu stated that "we can seize an historic opportunity — because, for the first time in my lifetime, and for the first time in the life of my country, Arab countries in the region do not see Israel as an enemy, but, increasingly, as an ally”. President Trump confirmed what the PM Netanyahu said in that "it is something that is very different, hasn't been discussed before. And it's actually a much bigger deal, a much more important deal, in a sense. It would take in many, many countries and it would cover a very large territory". In a Washington Post Op-Ed entitled "Could this be a game-changer for Middle East peace?" and shared by the Trump administration on August 25, 2017, David Ignatius wrote that "The Trump administration seems to 
envision an "outside-in" strategy for breaking the Palestinian-Israeli stalemate". He added that: "The opportunities for trade, investment, and security cooperation between Israel and the Arabs have never been greater". On January 22, 2018, in a joint press statement between VP Pence and PM Netanyahu, the latter remarked that Israel was ready to work with President Trump's negotiation team "to advance peace with all our neighbors, including the Palestinians". In short, this affirms that the Trump's strategy to the Israeli-Palestinian conflict followed a top-down "outside-in" approach.

\subsubsection{Triggering a change in perception: sharing common challenges and} interests

Results suggested that bridging the gap between the Arab states and Israel was often articulated by reference to the depiction of Iran as the real threat to the region. Put differently, triggering a change in perception of who represented the greatest threat to stability in the Middle East was central to reconciling between the Arab states and Israel. This meant that Israel throughout the corpus was presented as a potential partner in confronting a plethora of common issues while Iran was depicted as the main source of those issues.

In an op-ed shared by the Trump administration on September 4, 2018, Jason Dov Greenblatt highlighted the link between Iran's aggression in the region and the need for a change in perception of what is the source of threat and who could be a partner in confronting it. He wrote: "Confronted with an emboldened, aggressive Iran...most leaders understand now that Israel is not the problem — indeed, the Jewish state could be part of their solution". The "Peace to Prosperity" plan repeatedly argued that the Arab states should not perceive Israel as a threat. It emphasized that: 
"the State of Israel is not a threat to the region whatsoever. Economic conditions and Iran's malign activities, however, posed an existential threat to many of the region's states". A rapprochement between the Arab states and Israel would yield fruits at a myriad of levels, particularly at the level of security and economy. The plan insisted that "Integrating Israel into the region will allow it to assist across a wide range of economic challenges as well as counter the threats of Iran". It highlighted that "The State of Israel and the Arab countries have already discovered their common interests in combating terrorist groups and organizations and the common danger posed by an expansionist Iran" emphasizing that "These shared interest [sic] in the region should be expressed in closer ties between the State of Israel and the Gulf Cooperation Council".

In highlighting the opportunities to confront common challenges and pursue shared interests between the Arab states and Israel, the "Peace to Prosperity" plan devoted a separate section entitled "Opportunities For Regional Cooperation". In it, it said: "In confronting common threats and in pursuing common interests, previously unimaginable opportunities and alliances are emerging”. By bridging the gap between the two parties, they can together pursue mutual interests and meet those threats. It added: "The threats posed by Iran's radical regime, for example, have led to a new reality, where the State of Israel and its Arab neighbors now share increasingly similar perceptions of the threats to their security". The plan maintained that these new shared interests and challenges required more cooperation and collaboration: "We have entered a new chapter in the Middle East's history, in which courageous leaders understand that new and shared threats have created the need for greater regional cooperation. The Trump Administration has strongly encouraged this". Equally 
important, the "Peace to Prosperity" plan devoted another separate section that pinpointed the Trump administration's “Vision For Peace Between the State of Israel, the Palestinians, and the Region". It encouraged the Arabs states to fully normalize ties with Israel: "This Vision aims to achieve the recognition by, and normalization with, those countries who do not currently recognize the State of Israel or have a relationship with the State of Israel". In a nutshell, findings suggested that there was a correlation between the US policies towards Iran and the Israeli-Palestinian conflict; the "Maximum Pressure" strategy and the top-down "outside-in" approach crystallized in the "Peace to Prosperity" plan. Indeed, President Trump's remarks about the announcement of the normalization of ties between Israel and Sudan on October 23, 2020, nicely encapsulated this correlation. He said: "Had we not done what we did with Iran, this could never [sic] worked".

\subsubsection{Train of normalization}

On August 13, 2020, in his remarks on the announcement of Israel-UAE normalization of ties, President Trump pointed out that the Trump administration was already discussing further normalization of ties between Israel and other Arabs states. He said: "Now that the ice has been broken, I expect more Arab and Muslim countries will follow the United Arab Emirates' lead". On August 31, 2020, a joint statement stated that Israel carried out its first commercial flight to the UAE, flying over Saudi Arabia, which carried Israeli decision-makers and media outlets. In his remarks following the normalization of ties between Israel and Bahrain, Jared Kushner said: "It was the first time in 72 years that Saudi Arabia has now waived their airspace to allow commercial flights to fly from Israel back and forth". In eulogizing the efforts of the Trump administration, PM Netanyahu confirmed, on October 23, 2020, that the 
prospects for further normalization of ties with Arab states are indeed attainable and within reach. He said: "Well, I want to say that we are extending the circle of peace so rapidly with your leadership, Mr. President, your able team. History in the making. Actually, we're all making history — from the Emirates to Bahrain; now with Sudan and other countries that are in line".

\subsubsection{Motives/incentives behind the normalization of relations between the Arab states and Israel}

In examining the normalization of ties between the Arab states and Israel, the findings revealed that the motives and incentives were primarily twofold: economy and security.

\subsubsection{Economic motives/incentives to normalize ties between the Arab states and Israel}

Results showed that Israel was promoted and perceived as a potential economic partner in the region. The economic aspect was always identified when calling for the reconciliation of the Arab states with Israel. Some of the parties which participated in the "Peace to Prosperity" workshop held in June 2019 in Bahrain were all optimistic about the initiative. They considered the gathering of utmost importance not only for the Palestinians but also for the broader region. On May 19, 2019, Bahrain Minister of Finance and National Economy Shaikh Salman bin Khalifa Al Khalifa said: “The 'Peace to Prosperity' workshop underscores the close strategic partnership between the Kingdom of Bahrain and the United States as well as the strong and shared interest in creating thriving economic opportunities that benefit the region". In his remarks at the same workshop, Jared Kushner highlighted the economic opportunities that await the region if the gap is narrowed between the Arab 
states and Israel. He said: "We can turn this region from a victim of past conflicts into a model for commerce and advancement throughout the world".

The "Peace to Prosperity" plan pointed out that economic conditions in the Middle East “pose an existential threat to many of the region's states”. It encouraged the Arab states to forge economic ties with Israel to build stronger and more resilient economies. It said: "The goal of this Vision is to have the Arab states fully cooperate with the State of Israel for the benefit of all the countries in the region". The plan stressed that establishing economic ties with Israel would be mutually beneficial "particularly given the interests of the Arab countries to move away from economies based on fossil fuels to economies based on new infrastructure and technology". Equally important, cooperation included, among other things, direct flights between the states which would help "to promote cross-tourism, and to better enable Arabs to visit Muslim and Christian holy sites in Israel". It also called for the integration of transportation infrastructure which will transform the region into "a global hub for the movement of goods and services from Asia to Africa and Europe", in addition to the wide range of deals that could be developed in trade. The peace deals between UAE and Bahrain, and Israel signed on September 15, 2020, states that both states shall seek cooperation and bilateral agreements in investment, technology, innovation, trade, tourism, culture, energy, telecommunications, healthcare, environment, agriculture, water, among several other areas of utmost importance to strengthen the economy of these states. What was interesting was that the UAE-Israeli agreement highlighted the importance of the "diversification of bilateral trade opportunities" between the UAE and Israel. 
On October 23, 2020, the Republic of Sudan became the third Arab state that normalized relations with Israel under the auspices of the Trump administration. It was noticeable that the economic factor played an important role in such a peace deal making it a "pragmatic and unique deal" as described by a statement on the matter. Responding to a journalist's question, Secretary Pompeo said: "It made sense for the Sudanese people to build out their economy, to create democratic institutions - all the things that the Sudanese people have been demanding". Equally important, on December 11, 2020, the US-brokered peace between Israel and Morocco which both agreed to normalize diplomatic ties. Same as Sudan, the peace deal between the two states shed light on the mutual economic advantages while pointing out the security of Israel. A fact sheet stated that: "This expansion of the Abraham Accords further enhances Israel's security while creating opportunities for the two countries to deepen their economic ties and improve the lives of their people". The deal will empower Morocco to strengthen its bonds with the Moroccan Jewish community in Israel, as well. On December 10, 2020, the US officially recognized Moroccan sovereignty over the disputed Western Sahara territory. In a nutshell, the economic aspect factor was of paramount importance and significance in the normalization of ties between the Arab states and Israel.

\subsubsection{Security motives to normalize ties between the Arab states and Israel}

Repeatedly noticeable in the corpus was the security motive between the Arab states and Israel. Indeed, the horizons of security cooperation were strongly present in the very first joint statement by the Trump administration on the normalization of relations between Israel and the UAE. The statement of the announcement on August 13,2020 , pointed out that both countries will meet in the coming weeks to sign 
bilateral agreements in myriad fields among which were technology and security. Further, the statement declared that the three states will jointly create a "Strategic Agenda for the Middle East" to bolster cooperation in diplomacy, trade, and security. It also pointed out that the three states were committed "to promoting stability through diplomatic engagement, increased economic integration, and closer security coordination".

In a second document published by the Trump administration on the day of the announcement of the breakthrough between Israel and UAE, the fact sheet started with a quote by President Trump which summed up the link between bridging the gap between the Arab states and Israel and the importance of collective security: "Our vision is one of peace, security, and prosperity — in this region, and in the world. Our goal is a coalition of nations who share the aim of stamping out extremism and providing our children a hopeful future that does honor to God". The security field was mentioned twice in the same document. The importance of security cooperation with Israel was not exclusive to the UAE. The normalization of ties between Bahrain and Israel on September 11, 2020, also highlighted the importance of such an agreement on collective security. In a news clip, the Trump administration stated that the decision "further enhances their security while creating opportunities for them to deepen their economic ties". In a fact sheet published on September 15, 2020, the Trump administration reiterated that by bridging the gap between the Arab states and Israel, "these agreements are leading to peace between Israel and the Middle East, as well as increased security in the region".

With relation to the establishment of diplomatic ties between Sudan and Israel on October 23, 2020, what was noteworthy is that while Sudan benefited mostly from 
the economic advantages, as demonstrated in the previous section, this agreement further served Israel's security. The fact sheet stated that: "The expansion of the Abraham Accords to include Sudan is a significant step that will further enhance Israel's security and create opportunities for Sudan and Israel to deepen their economic ties and improve the lives of their people". Lastly, one of the clauses of the Abraham Accords Declaration stipulated that the signatory parties jointly embark on a vision of mutual security for a peaceful and prosperous future. It said: "We pursue a vision of peace, security, and prosperity in the Middle East and around the world". Briefly, similar to the economic one, the security aspect was of utmost importance and significance in the normalization of ties between the Arab states and Israel.

\subsubsection{A mixture of multilateralism and unilateralism}

Similar to its approach to contain Iran, data showed that the US, in addressing the Israeli-Palestinian conflict, acted both multilaterally and unilaterally. What was noticeable was that the US preferred to suggest a solution to the conflict that was most of the time not in accordance with international consensus.

\subsubsection{Multilateralism through "shuttle diplomacy"}

Following a multilateral approach in which different parties were consulted, the Trump team conducted a "shuttle diplomacy" in the region in an attempt to reach a comprehensive solution to the Israeli-Palestinian conflict. In a joint press conference with President Trump on April 5, 2017, King Abdullah appreciated the engagement of President Trump's team and valorized their endeavor to consult with all parties affected by a peace resolution. He said: "And so, his team had been in the region, they've been talking to all the partners". The "Peace to Prosperity" workshop held in 
June 2019 attested to the consultation with different parties in the region. Yet multilateralism was eventually overridden by heavy doses of unilateral decisions.

\subsubsection{Unilateralism: The US approached the Israeli-Palestinian conflict in a manner consistent with its national interests and not necessarily in accordance with international norms}

The Trump administration stressed that it would do whatever it takes, even disregarding international norms, to defend US interests. In his address to the Arab Islamic American Summit on May 21, 2017, President Trump declared: "We will discard those strategies that have not worked - and will apply new approaches informed by experience and judgment". He added: "We will make decisions based on real-world outcomes - not inflexible ideology". In his remarks at the 2019 AIPAC Policy Conference on March 25, 2019, VP Pence commented on the Trump administration's policies towards the Israeli-Palestinian conflict saying: "Our President made these decisions in the best interest of the United States". The "Peace to Prosperity" plan considered that approaching the Israeli-Palestinian conflict through the UN bodies was ineffective and proved to be fruitless. It said: "Since 1946, there have been close to 700 United Nations General Assembly resolutions and over 100 United Nations Security Council resolutions in connection with this conflict". For the Trump administration, "these resolutions have not brought about peace". It points out how these resolutions were "sometimes inconsistent and sometimes time-bound". It also recalled how some of them were even ambiguous and subject to "conflicting interpretations" from different states and legal scholars such as United Nations Security Council Resolution 242. In brief, the Trump administration was upfront about its perception of how to approach the Israeli-Palestinian conflict. 
The "Peace to Prosperity" plan unambiguously stated that the administration will not rely on the UN bodies nor previous resolutions to come up with a realistic and comprehensive plan for the chronic conflict. It maintained that:

this Vision is not a recitation of General Assembly, Security Council and other international resolutions on this topic because such resolutions have not and will not resolve the conflict. For too long these resolutions have enabled political leaders to avoid addressing the complexities of this conflict rather than enabling a realistic path to peace.

When it comes to criticizing the UN stances towards Israel, this was repeatedly identifiable within this corpus. In a fact sheet entitled 'President Donald J. Trump Stands by America's Cherished Ally Israel' issued on March 25, 2019, the Trump administration lambasted the UN's "unfair treatment of Israel" stating that

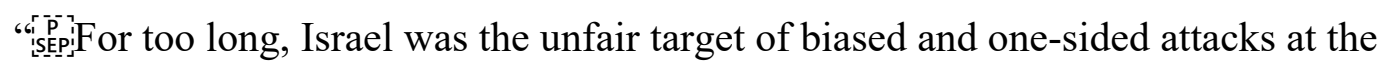
UN". It highlighted the President's decision to pull out from the UN Human Rights Commission for showing "abhorrent anti-Israel bias". Additionally, on different occasions, the Trump administration took pride in cutting funds to the United Nations Relief and Works Agency for Palestine Refugees (UNRWA) as it was plagued by mismanagement and represented a hurdle in the peace process. In short, the Trump administration was not enthusiastic about working with the United Nations nor following international consensus. Instead, it criticized the UN agencies and approached the Israeli-Palestinian conflict purely from the US national interests perspective. 


\subsection{On Jerusalem}

The Trump administration unilaterally recognized Jerusalem as the "undivided" capital of Israel. On December 6, 2017, in a presidential proclamation, the President reiterated that the Jerusalem Embassy Act of 1995 (Public Law 104-45), urged the US to recognize Jerusalem as the capital of Israel and relocate the US embassy to the new capital. This came after the US Senate voted unanimously on June 5, 2017, to reaffirm the Act. To show support for President Trump's decision to recognize Jerusalem as Israel's capital, the Trump administration published a statement on December 7, 2017, which included the views of US senators and representatives, advocacy organizations, and Israeli officials such as the Prime Minister and the President. What was noticeable was that there was no view of any other foreign leader supporting the decision as was the case with other decisions such as the creation of a new strategy on Iran or the withdrawal from the JCPOA. The "Peace to Prosperity" plan came to insist that Jerusalem "should be internationally recognized as the capital of the State of Israel'. For the State of Palestine, its capital could be named "Al Quds" or any other name as determined by the State of Palestine and should be internationally recognized.

\subsection{On settlements}

The "Peace to Prosperity" plan justified Israeli sovereignty over the territories captured in the 1967 war as it viewed the latter as a defensive war. It stated that "Withdrawing from territory captured in a defensive war is a historical rarity". In his remarks with PM Netanyahu on January 28, 2020, President Trump emphasized that: "No Palestinians or Israelis will be uprooted from their homes". PM Netanyahu commented: "For too long — far too long — the very heart of the Land of Israel 
where our patriarchs prayed, our prophets preached, and our kings ruled, has been outrageously branded as illegally occupied territory. Well, today, Mr. President, you are puncturing this big lie". However, for the Trump administration, as underscored in the plan, Israel had to stop expanding existing settlements or build new ones. This was part of the compromises that Israel had to make to enhance peace prospects with the Palestinians. In relation to occupation, the corpus revealed that the Trump administration throughout its mandate did not refer to or consider the Israeli settlements as occupied Palestinian territories. In fact, even in the "Peace to Prosperity" plan, occupation, as a term, is used by the Trump administration to signify solely jobs and training.

\subsection{On Refugees}

The "Peace to Prosperity" plan pointed out that the chronic conflict between the Arabs and the Israelis caused a refugee problem for both the Palestinians and the Jews. It stated that "Nearly the same number of Jews and Arabs were displaced by the Arab/Israeli conflict". The plan reminded the Arab states of their "moral responsibility" to integrate the Palestinians, the same way Israel integrated the Jewish refugees. As for their return to Israel, the plan unambiguously stated that "There shall be no right of return by, or absorption of, any Palestinian refugee into the State of Israel "SESP In a nutshell, the decisions and characteristics of the Trump administration's approach to the Israeli-Palestinian conflict made it indeed unique and distinct from the previous approaches. 


\subsection{Limited Sovereignty of the Palestinian State and the maintenance of the security of Israel}

Results showed that the statehood of the State of Palestine was often envisioned in reference to the security of Israel. President Trump's 'peace plan' places restrictions on the sovereignty of the State of Palestine that were, in the eyes of the Trump administration, so important to maintain the security of Israel if a genuine and lasting peace was desired by all parties. While the plan recognized that the Palestinians "have a legitimate desire to rule themselves and chart their own destiny", it focused on the concept of self-determination at the expense of sovereignty. It maintained that "Any workable peace agreement must address the Palestinians' legitimate desire for self-determination" with no reference to Palestinian sovereignty in case of a statehood. According to the plan, "Self-determination is the hallmark of a nation. This Vision is intended to maximize self-determination while taking all

relevant factors into account.ssep Sovereignty is an amorphous concept that has evolved over time". The plan viewed sovereignty, as a concept, as not "static" and has no definite and definitive definition. It was within this context that "A realistic solution would give the Palestinians all the power to govern themselves but not the powers to threaten Israel". In short, for the Trump administration, a practical and lasting solution to the Israeli security concerns "necessarily entails the limitations of certain sovereign powers in the Palestinian areas".

Regarding the new Palestinian state, the plan addressed the legitimate aspirations of the Palestinian people through, among others things: the establishment of the State of Palestine, assisting with building new infrastructure, strengthening institutions, etc. At the same time, the plan placed particular importance on the 
security of Israel for it was "a country that since its establishment has faced, and continues to face, enemies that call for its annihilation". The plan expressed the administration's concern about the bellicosity of Hamas, noting that "a similar regime controlling the West Bank would pose an existential threat to the State of Israel".

If the Israelis and the Palestinians signed a peace agreement, Israel will be the main responsible for the security of Palestine. This entailed that the Palestinians would have to assume their responsibility in terms of their internal security. Accordingly, Israel hoped to minimize its involvement inasmuch as Palestine took matters into its own hands. Among the Israeli rights to maintain security and order was the use of aerial technology such as drones. This will help to mitigate the Israeli footprint in the Palestinian territories. Moreover, Israel retained its right to deny the entry of weapons or any related materials that it deems dangerous to its security to Palestine. Furthermore, Palestine was not allowed to enter any international organization if Israel deems critical to its national security, be it; militarily, politically, or judicially. In all cases, Palestine should obtain the consent of Israel before joining any organization. In addition to that, Palestine was not allowed to make any agreement, be it at the level of security, military, or intelligence, with any other organization or state that put Israel's security in peril. Similarly, it should be denied the development of any military capability locally or externally that could endanger Israel. Equally importantly, in case of any breach of these security premises, Israel had the right to "engage in necessary security measures" to ward off any threat to its national security. Last but not least, for security reasons, Israel exercised full control and sovereignty on the Jordan Valley and the territorial waters. In a nutshell, the Trump administration suggested tremendous restrictions on the requirements of the 
new Palestinian state which, unsurprisingly, did not meet the demands of the Palestinians.

\subsection{Triggering geopolitical transformation to confront Iran's quest for regional hegemony}

Results suggested that the Trump administration worked towards triggering a geopolitical transformation in the Middle East. For the administration, new emerging threats required a shift in US strategies and regional dynamics. In this section, I demonstrate how the Trump-era foreign policies in the region aimed at forging a new geopolitical architecture by rebuilding trust with allies, rallying partners, and eventually changing alignment patterns to confront the growing influence of Iran.

\subsubsection{Rebuilding mutual trust}

Data showed that the Trump administration vocally expressed its intentions to rebuild mutual trust between the US and its partners and allies in the Middle East, after what was viewed as a period of skepticism and uncertainty. On May 22, 2017, the administration issued a statement reflecting the reaction of President Reuven Rivlin of Israel upon President Trump's arrival in Israel. President Rivlin said: "we are happy to see, America is back in the area, America is back again." On September 20, 2017, about his address to the 72nd United Nations General Assembly, a fact sheet was issued stating that "The President is repairing relationships with Israel, Saudi Arabia, and other key Middle Eastern allies and partners. In his remarks on May 8, 2018, on the JCPOA, President Trump said: "Today's action sends a critical message: The United States no longer makes empty threats. When I make promises, I keep them". In his announcement of the normalization of relations between Israel and 
Bahrain on September 11, 2020, President Trump said: "I've restored trust with our regional partners".

\subsubsection{Rallying partners}

Throughout the corpus, findings demonstrated that the Trump administration consistently rallied US partners to confront the Iranian threat to collective security and regional peace. Indeed, the administration aimed at aligning the Arab states and Israel and propelling them to form a security coalition to thwart the growing threat of Iran. In a joint press conference with PM Netanyahu on February 15, 2017, President Trump expressed his intentions to rally US partners and allies in the Middle East to confront Iran's aggression in the region. He said:

I think it's - let me say this very openly: I think it's long overdue, and I think that if we work together — and not just the United States and Israel, but so many others in the region who see eye to eye on the great magnitude and danger of the Iranian threat, then I think we can roll back Iran's aggression and danger. And that's something that is important for Israel, the Arab states, but I think it's vitally important for America.

President Trump pushed for a security alignment between the Arab states and Israel in that the Arabs states needed to realize that they cannot always rely on the US for their security. Instead, Israel might be a strategic solution and a reliable partner for them in the long run. The Trump administration's appeal for the security alignment between the Arab allies and Israel also seemed to constitute a stepping stone for a long-term strategic alternative for the US disengagement from the Middle East. In his same address to the Arab Islamic American Summit, President Trump noted: "But the nations of the Middle East cannot wait for American power to crush this enemy for 
them. The nations of the Middle East will have to decide what kind of future they want for themselves, for their countries, and for their children".

On October 13, 2017, in outlining the new strategy on Iran, the Trump administration noted that "We will revitalize our traditional alliances and regional partnerships as bulwarks against Iranian subversion”. On May 8, 2018, in a fact sheet about the US withdrawal from the Iran Nuclear Deal, the Trump administration reaffirmed that: "President Trump will work to assemble a broad coalition of nations to deny Iran all paths to a nuclear weapon and to counter the totality of the regime's malign activities". In a statement published on May 9, 2018, displaying the support for President Trump's decision to withdraw from the Iran Nuclear Deal, it stated what Secretary of State Pompeo said about the decision:

As we exit the Iran deal, we will be working with our allies to find a real, comprehensive, and lasting solution to the Iranian threat. But our effort is broader than just the nuclear threat and we will be working together with partners to eliminate the threat of Iran's ballistic missile program; to stop its terrorist activities worldwide; and to block its menacing activity across the Middle East and beyond

In his remarks to the 73rd Session of the United Nations General Assembly on September 25, 2018, President Trump said: "For that reason, the United States is working with the Gulf Cooperation Council, Jordan, and Egypt to establish a regional strategic alliance so that Middle Eastern nations can advance prosperity, stability, and security across their home region". In the remarks of President Trump on the announcement of normalization of relations between Israel and Bahrain on September 11, 2020, VP Pence recalled that: "Your very first foreign trip was to the Arab world 
— to reach out, to create new alliances". In a joint statement by the US, Bahrain, and Israel on October 19,2020, the three states agreed that they will "advance a Strategic Agenda for peace and prosperity in the Middle East" adding that they "are aligned in their views on the challenges, threats, and opportunities present in the region".

\subsubsection{Creating a geopolitical shift}

Allied to the Trump administration's efforts to rebuild trust and rally partners was its efforts to trigger a geopolitical shift in the Middle East. This shift was achieved by pushing for a security alignment and altering the power dynamics in the region. Findings suggested that by moving the Arab states closer to Israel, as illustrated in the Abraham Accords, cooperation in the field of security could be a turning point in altering the geopolitical arena where all parties have a deep interest in rolling back Iran's destabilizing behavior.

On October 13, 2017, the Trump administration issued a fact sheet hoping that the "Maximum Pressure" strategy on Iran will "restore a more stable balance of power in the region". On January 22, 2018, in his remarks in the special session of the Knesset, VP Pence appreciated that the region is undergoing a "remarkable transformation" and stressed "the need to forge a new era of cooperation". He also added that: "The winds of change can already be witnessed across the Middle East. Longstanding enemies are becoming partners. Old foes are finding new ground for cooperation".

In a separate section of the "Peace to Prosperity" plan entitled "New Opportunities for New Regional Security Initiatives”, the Trump administration pointed out the prospects of forming alliances to balance against the common threat of Iran in the Middle East. It said: "In confronting common threats and in pursuing 
common interests, previously unimaginable opportunities and alliances are emerging". It also recognized that “The threats posed by Iran's radical regime, for example, have led to a new reality, where the State of Israel and its Arab neighbors now share increasingly similar perceptions of the threats to their security". On September 15, 2020, a fact sheet was issued affirming that the US is "facilitating a regional transformation" in the Middle East and that "President Trump's policies are leading to the most rapid geopolitical transformation of the Arab world in more than a generation".

This regional transformation that the Middle East was witnessing was aimed to benefit the interests of the US and its allies while curbing Iran and its proxies in the region. On October 23, 2020, in the President's remarks about the announcement of the normalization of ties between Israel and Sudan, Brian Hook lauded the "transformative diplomacy that has been led by the President" adding that "the President has stood with Israel and countered Iran, and that has given space to our Arab partners to move closer to Israel". He also boasted that "with three peace agreements, this is now the third defeat for Iran's foreign policy, and it is another victory for America". In the same respect, President Trump said: “And I want to say - one thing that I do see is an enthusiasm from most countries in the world, for most people in the world - across the political divide. Yeah, Iran is unhappy. Hezbollah is unhappy. Hamas is unhappy".

The UAE-Abraham Accords Peace Agreement signed on September 15, 2020 , included clauses that demonstrate mutual interests between the parties notably in the field of security cooperation, so important for the geopolitical shift that the Trump administration envisioned. For instance, the agreement stated that the parties were: 
"Determined to ensure lasting peace, stability, security and prosperity for both their States". Further, the agreement stipulated that both parties will allow each other's cargoes and vessels to access each other's different ports and that both "Parties shall conclude agreements and arrangements in maritime affairs, as may be required". Additionally, security cooperation also included the energy field as "The Parties take note of the strategic importance of the energy sector and in particular of their need to promote... energy security". Last but not least, the two parties "Reaffirm[ed] their shared commitment to normalize relations and promote stability through diplomatic engagement, increased economic cooperation and other close coordination”. Similarly, the normalization of ties between Bahrain and Israel on September 11, 2020, also pointed out the importance of such an agreement on mutual security. It should be stressed that after starting to see their efforts bear the fruit, members of the Trump administration praised the consistency and vision of the American foreign policy in the Middle East. In the President's remarks on the announcement of normalization of relations between Israel and the Kingdom of Bahrain on September 11, 2020, Kushner said that this success was "the culmination of a long period of time". He added: "And all of the promises you made on that trip and all of the things that you foreshadowed have occurred. It's been a strategy that you've stuck with". Similarly, Brian Hook lauded the President's strategy saying that: you talked about the journey to get here. And I remember I heard you pledge, when you were in Riyadh and when you were in Israel — you pledged that you would strengthen America's friendships and to build new partnerships in the pursuit of peace. And you've kept that promise, and we see that very clearly today. 
To conclude, my empirical data revealed that the Trump administration embarked on two shifts in its foreign policies towards Iran and the Israeli-Palestinian conflict. It followed a confrontational "Maximum Pressure" campaign to better contain Iran's destabilizing behavior in the region. The pursuit of this strategy is considered as a much-needed approach after a period of rapprochement for which the Obama administration was harshly criticized. The administration also pursued a topdown "outside-in" approach towards the Israeli-Palestinian conflict. The "Peace to Prosperity" plan came to convey President Trump's vision of a new Middle East. Interestingly, the entire approach focused on bridging the gap between the Arab states and Israel. This was evident by stressing the importance of economic and security cooperation between the Arab states and Israel while placing tough restrictions on the would-be State of Palestine. The Trump administration also worked towards creating a geopolitical transformation in the region. It rallied the US allies to form an alliance or a coalition of states that would better contain Iran and its proxies in the region. 


\section{Chapter Five: Discussion}

Using an inferential interpretive approach, data discussion in this chapter sets out to understand the layers of meaning inherent in the research findings. First, I attempt to develop a better understanding of the strategic shift identified in the American foreign policy in the Middle East under the Trump administration. Second, I attempt to generate insights into its geopolitical implications, the most important of which is a burgeoning security alignment between the GCC states (UAE, Bahrain, and even Saudi Arabia secretly) and Israel, so strategic to help thwart Iran's growing influence as the US recalibrates its engagement in the region. Research results were relevant to my research questions and suggested that the policies designed towards Iran and Israeli-Palestinian questions were correlated and both playing into the dynamics of geopolitical transformation. What made the Trump-era foreign policies strategic was the adoption of new approaches and the thoughtful pursuit of a transformative geopolitical vision of the region. While other scholars and analysts described the shift that marked the American foreign policy as "titanic" (para. 1) and “decisive" (Gingrich, 2017, para. 8), and "significant" (Quamar, 2018, p. 273), my findings suggested it was indeed strategic and had a transformative effect on regional geopolitics in line with the US increasing retreat from the region. Pushing for a security alignment between the GCC states and Israel may help the US, in the long run, to switch into an "Offshore Balancing" strategy as it can rely more effectively on key regional allies which by then would have developed an extensive experience of security cooperation.

This chapter is divided into four main sections. The first one is about the adoption of a new confrontational approach regarding Iran: the "Maximum Pressure" 
campaign. The second one is about the adoption of a new top-down approach regarding the Israeli-Palestinian conflict crystallized in the "Peace to Prosperity" plan. The third section is a discussion of the resort to both unilateralism and multilateralism often in defiance of international consensus. The last section in the chapter is about the geopolitical transformation engendered by the two policies towards Iran and the Israeli-Palestinian conflict. In it, I attempt to apply Ryan's (2009, 2015) ‘regime security' theory.

\subsection{The adoption of the "Maximum Pressure" campaign towards Iran}

The Trump administration unreservedly demonized Iran and its proxies in the Middle East. It assiduously sought to reinforce the idea that Iran and its aligned groups are the common arch-foe to the US and its allies. For the administration, Iran and its clients have a long history of viciously targeting the security of the US and its allies and, thus, are the ones to blame for the region's plights. It is within this context that the Trump administration championed the idea that the overall destabilizing actions of Iran and its proxies, not just the nuclear portfolio, have been at the forefront of its Iran strategy. In this regard, it relentlessly criticized the Obama administration's handling of issues ranging from the rapprochement with Iran to the use of chemical weapons by the Syrian regime. In fact, the administration did not show any restraint in indicting the previous administration's rapprochement with Iran which allegedly gave it a blank cheque to carry on its threatening behavior in the region. This included Iran's development of Intercontinental Ballistic Missiles (ICBM) and funding terrorist groups, among other malicious activities. It was as if the shortsightedness of the American foreign policy was complicit in Iran's pursuit of its hegemonic aspirations in the region, much to the detriment of the US interests and the security of US allies. 
Based on its absolute dissatisfaction with the JCPOA, the Trump administration, throughout its mandate, worked systematically to dismantle the US rapprochement with Iran. It unilaterally pulled out from the Iran deal and reinstated unilateral tough sanctions on the Iranian regime. Indeed, the Trump administration's "Maximum Pressure" campaign illustrates how the Trump administration opted for a confrontational approach, quite different from the past US approaches, which used dialogue, negotiation, and cooperation with the EU and the rest of the international community. In particular, the Obama administration's approach advocated fervently for diplomatic engagement with Iran, as shown in the 'Historical background and literature review' chapter. On Trump's approach, Quamar (2018) affirms that "Undoubtedly, it is a clear departure from the Obama's policy of a nonconfrontationist approach" (p. 284). This shift, which I discuss in-depth in the fourth section of this chapter, is a vital part of Trump's vision to push for geopolitical transformation, hence Arab-Israeli security alignment.

\subsection{The adoption of a top-down approach regarding the Israeli-Palestinian conflict, President Trump's “Peace to Prosperity" plan}

The Trump administration has shrewdly focused on bridging the gap between the Arab states and Israel. It heavily invested in a top-down "outside-in" approach, quite different from the US previous approaches. The restrictions imposed on the future Palestinian state prove that the administration was focusing on reconciling between the Arabs states and Israel, in lieu of pushing for direct negotiations between the Israelis and the Palestinians. This proves that the 'Land-for-Peace' formula was not that appealing for both the Trump administration and Israel since they could engineer a much more magical deal based on a 'Peace-for-Peace' principle. 
The severity of the restrictions on the sovereignty of the envisioned State of Palestine makes it unlikely that the Palestinians would seriously consider the plan given their vehement embrace of the spirit of the Arab Peace Initiative and the numerous UNSCRs. It is, therefore, no surprise that the Trump administration tailored such restrictions in the 'peace plan' on purpose perfectly knowing that the Palestinians will unapologetically reject it, thus exposing their inflexibility and intransigence in the peace process. By portraying the Palestinians' unalterable stance, across the different factions and orientations, as a hinder towards lasting and comprehensive peace, the Trump administration paved the way for the Arab states to break away from the Palestinian's sheer obstinacy and chart a new path for their regimes. It is worth remembering that, "Without doubt", former President Jimmy Carter asserted, "the path to peace in the Middle East goes through Jerusalem" (as cited in Totten, 2016, p. 28). The Trump administration did exactly the opposite. It disregarded the need for a genuine breakthrough between the Israelis and the Palestinians and shifted instead its focus on the wider issues, on which the US has a certain amount of leverage, between some of the Arab states and Israel.

The plan demeans any future peace prospect between the Israelis and the Palestinians, one that is genuine, realistic, and lasting. It killed the 'Land-for-Peace' principle that the Palestinians demand for serious negotiations, a principle that also underlies the Arab Peace Initiative. Odeh (2020) corroborates that the Israel-UAE rapprochement, encouraged by the Trump administration, leads to the marginalization of Palestinian rights. In her words, "The UAE-Israel deal ushers in an alliance that defies traditional common denominators and sidelines the Palestinian cause" (para. 7). The reaction of the Palestinians against the "Peace to Prosperity" plan and the 
Abraham Accords came to corroborate the top-down approach that characterized the Trump administration's initiative to resolve the Israeli-Palestinian conflict. Ferziger and Bahgat (2020) point out that the plan failed to relaunch peace talks between the Israelis and the Palestinians as the latter immediately and categorically rejected it. Indeed, Palestinian Authority leader Mahmoud Abbas described the plan as the "smack of the century", asserting that the unjust plan strives to "liquidate the Palestinian issue" (Neuman \& Kennedy, 2020, para. 10).

Yet, looking appealing, the plan had active listeners among certain Arab states who welcomed it with open arms. Indeed, by the end of its tenure, the President's approach started to bear fruit with refueling the train of normalization that kickstarted with Egypt in 1978. While the UAE claims that the peace deal with Israel would help halt Israeli settlements, thus narrowing the gap between the Israelis and Palestinians to sit on the table and relaunch the peace process, scores of analysts note that the Abraham Accords are not peace deals since none of the signatory Arab states have been in war with Israel. For instance, Guzansky and Marshall (2020) write: "There are no territorial disputes between them, nor any grievances or accounts to be settled between their political elites or peoples" (p. 383). The same applies to the Bahraini case.

It is no secret that, prior to the normalization of relations, certain Arab states forged warm relations with Israel. According to Guzansky and Marshall (2020), Bahrain had already ended its boycott of Israel in 2005, and how the leaked documents of Bahrain's King Hamad bin Isa Al-Khalifa in WikiLeaks had illustrated his official order to stop referring to Israel as the "Zionist entity" (p. 381). Erdoğan and Habash (2020) underscore that some of the Gulf states were central in the 
promotion of the "Deal of the Century" especially Bahrain which hosted the "Peace to Prosperity Workshop" in Manama in 2019. Ferziger and Bahgat (2020) affirm that the discretion of ties between the Gulf states and Israel began to ease before the normalization of ties. They recall how former Sultan Qaboos bin Said of Oman welcomed Israeli PM Benjamin Netanyahu in his palace in late 2018 and how Israel will partake in the World Expo hosted by the UAE in 2021 indicating that "the Jewish state's presence is becoming more overt in places where it was previously kept quiet or outright barred" (p. 2). In the same context, in 1996, Oman and Qatar established trade offices for commercial relations with Israel, even though they were shut down in 2000 in solidarity with the Palestinians following the Second Intifada. In short, reinvigorating the train of normalization with Israel seems to have shattered the Israeli taboo. While one might wonder that this was already the case with Egypt and Jordan in 1979 and 1994 respectively. Yet while Egypt and Jordan shared borders and a history of war and hostility with Israel, the UAE was not subject to these factors.

Regarding the Saudi stance towards the rapprochement with Israel, it appeared more lenient even though it gave mixed signals. On the one hand, it most probably gave the green light for Bahrain and UAE to move ahead with the normalization of relations. On the other hand, Saudi Foreign Minister Prince Faisal bin Farhan, just a few days after the announcement of the deal between Israel and UAE, stressed the need to settle the Palestinian question first in accordance with the Arab Peace Initiative put forward in 2002 before normalizing ties (Guzansky \& Marshall, 2020). Overall, one could deduce that the new leadership of Saudi Arabia, with the Crown Prince Mohammad Bin Salman, also known as MBS, as the de facto ruler, seems to be more lenient towards détente with Israel. Indeed, in his visit to the US in April 
2018, he was upfront in his stance towards Israel and declared that both the Israelis and Palestinians have "the right to have their own land" (Goldberg, 2018, para. 7). In the same visit to the US in April, during his meeting with certain Jewish groups, MBS commented that the Palestinians should "accept Trump proposals or shut up' after slamming their rejectionist stances to previous peace initiatives (Al Jazeera, 2018, title).

Other states unequivocally rejected the top-down approach such was the case with Kuwait. According to Al-Qabas, a Kuwaiti newspaper, Kuwaiti government sources assured that Kuwait's firm stance on normalizing relations with Israel is "fixed and will not change" (as cited by The New Arab Staff, para. 2, 2020a). As far as Iran's reaction is concerned, Iran's IRGC condemned in the strongest terms the normalization of ties between UAE and Israel and warned that such a deal would lead to a "dangerous future" (para. 7) for the UAE. For its part, the government-allied and ultra-conservative newspaper Kayhan wrote what was considered as a threatening warning: "The UAE's great betrayal of the Palestinian people...will turn this small, rich country, which is heavily dependent on security, into a legitimate and easy target” (as cited by Shepp, 2020, para. 7).

\subsection{American foreign policy with a heavy dose of unilateralism}

Throughout its mandate, the Trump administration was scathingly critical of the United Nations with its different agencies. On several occasions, it eschewed working with the UN in addressing some of the most pressing issues in the Middle East: Iran's alleged malign activities and the longstanding Israeli-Palestinian conflict. However, on other issues such as the Syrian civil war, the administration did not object to pushing for a diplomatic political solution, under the auspices of the UN, 
simply because the war in Syria did not represent a US foreign policy priority. In what follows, I discuss the Trump administration's embrace of unilateralism that often contradicted international norms.

\subsubsection{On Iran}

Although the Trump administration took a unilateral decision in shredding the JCPOA, it undeniably consulted with its regional partners, among which were Israel, Saudi Arabia, and UAE. Accordingly, the administration seemingly changed the US multilateral mechanism in its containment of Iran in that it sidelined both the United Nations and the European allies, both constituted pillars in the last 2 decades in negotiating with Iran, as discussed in the Second Chapter. Yet following the US withdrawal from the JCPOA, the UN and EU, among others, voiced their regret on the unilateral decision. The UN Secretary-General presented a report, '(S/2018/602)', on June 12, 2018, reiterating that resolution 2231, in favor of the JCPOA, was fully implemented and respected by Iran. The report confirmed that Iran "has been implementing its nuclear-related commitments under the Joint Comprehensive Plan of Action" and considers the US withdrawal from the deal a "setback" to the whole process (UN Secretary-General, 2018, p. 1). Similarly, the EU expressed its deep regret of the US unilateral move highlighting that the JCPOA "is the culmination of 12 years of diplomacy which has been working and delivering on its main goal" (Council of the European Union, 2018, para. 5). This clearly indicates that, in the Trump era, the United Nations was sidelined and the Europeans were replaced by the US closest allies in the region.

As part of its sustained effort to thwart the JCPOA, the US suggested, in August 2020, a draft resolution '(S/2020/797)' to the UN Security Council which 
would extend the restrictions on Iran regarding arms set to expire in October 2020. The US failed, however, to pass the resolution with only the US and the Dominican Republic voting in favor, while China and Russia vetoing the draft, and the remaining Council members abstaining from voting. In the same month, the US tried to reimpose the pre-2015 UN sanctions by invoking its "snapback" (para. 6) right under the JCPOA but failed once again (Scheffer, 2020). Hence, even though the US actions were taken through the UN Security Council, there were yet again unilateral moves by the Trump administration which only resulted in more isolation of the US on the world stage.

Further, in another effort to contain Iran and its proxies, the Trump administration unilaterally recognized the Israeli sovereignty over the Golan Heights, a decision that spawned worldwide criticism. Members in the UN Security Council vocally expressed their regret over the decision with the EU members stating that "Annexation of territory by force is prohibited under international law," reaffirming that unilateral annexation of other territories is in defiance of "the rules-based international order and the UN Charter" (as cited in Deutsche Welle, 2019, para. 6). It is worth remembering that, following the annexation of the Golan Heights by Israel, the Security Council adopted Resolution 497 on December 17, 1981, in which it highlighted that "the acquisition of territory by force is inadmissible" (PP 2). Besides, it unequivocally recognized the captured territories as "occupied Syrian Golan Heights" and that Israeli's control over the area "is null and void and without international legal effect" (OP 1). Equally important, the resolution stipulated that "Israel, the occupying Power, should rescind forthwith its decision" (United Nations, 1981, OP 2). 
To conclude, the Trump administration's espousal of unilateralism regarding Iran manifested itself in the withdrawal from the JCPOA, the reimposition of economic sanctions, the suggestion of security council resolutions, and recognition of Israel's sovereignty on the Golan Heights. These moves were testimonial to the assertive and confrontational aspect of the Trump administration approach regarding Iran, yet they were at the same time self-isolating actions in the international arena. Indeed, using diplomatic means, the $\mathrm{EU}$ and the international community resorted to 'soft balancing' against the US as a response to its unilateralism as expected by Pape (2005). Certainly, these moves marked a shift from the past approaches where the US worked closely with its international partners, especially the EU, to address Iran's nuclear program and growing influence in the Middle East.

\subsubsection{On the Israeli-Palestinian conflict}

After the repeated renunciation of the past approaches in handling the longstanding Israeli-Palestinian conflict, it became crystal clear then that the Trump administration would take a different path driven by a "realistic" and "pragmatic" regional approach. In dealing with the conflict, the Trump administration touted itself as a unique deal maker and peace broker. However, for the administration, in order to be successful, it should be unshackled by the failed approaches of the past, even though at the expense of international norms, which, according to the administration, used to hinder the peace process. Indifferent to these constraints, President Trump took a number of unilateral decisions regarding Jerusalem, Israeli settlements in the West Bank, the Palestinian refugee question, but also a wide range of other issues that drew a flurry of criticism leading many to question the US role as a neutral peace broker in the Israeli-Palestinian conflict. 
When the Trump administration overturned decades of American foreign policies towards the Israeli-Palestinian conflict by recognizing Jerusalem as the capital of Israel, it faced widespread criticism from the international community, including the closest allies of the US. The unilateral recognition of Jerusalem broke with a longstanding international consensus that the status of Jerusalem should remain unresolved until the Israelis and the Palestinians find a common ground to resolve it. Similarly, on December 21, 2017, the overwhelming majority in the UN General Assembly voted for resolution 'GA/11995' which rebuked the Jerusalem decision by the Trump administration. As a response to that, the US threatened the states who voted in favor of the resolution with punitive actions such as cutting foreign aids (Fassihi, 2017). With the US standing alone in defending its unilateral decision, it used its veto to reject a security council resolution on the matter. Yet the fact that all members in the council except the US voted to adopt the resolution drew the attention of scores of analysts who regarded the vote as a rebuke to the Trump administration's unilateral decision. Gladstone (2017) writes:

The rebukes, made at an emergency Security Council meeting called over Mr. Trump's announcement, constituted an extraordinarily public denunciation of American policy on the world's most prominent diplomatic stage, leaving the United States alone on the issue among the council's 15 members. (para. 2) Regarding the question of settlements, the "Peace to Prosperity" plan does not view Israeli settlements as illegal. On the contrary, it recognizes and endorses Israeli sovereignty over large swathes of areas in the West Bank. It runs counter to the international consensus on the Israel-Palestinian conflict. In addition to the Arab world, the EU, a close ally to the US, condemned the US policy reversal on the Israeli 
settlements. In a statement, the EU reaffirmed its "clear" and "unchanged" stance that "all settlement activity is illegal under international law and it erodes the viability of the two-state solution and the prospects for a lasting peace" (para. 1). The EU also urged Israel "to end all settlement activity", referring to it as the "occupying power" (Mogherini, 2019, para. 2). In the same vein, UNSCRs which condemn the Israeli settlements are numerous. By way of example, Resolution 446 adopted on March 22, 1979 "Determines that the policy and practices of Israel in establishing settlements in the Palestinian and other Arab territories occupied since 1967 have no legal validity" (OP1) and demands Israel, referring to it as "the occupying Power", "to abide scrupulously by the 1949 Fourth Geneva Convention" (United Nations Security Council, 1979, OP3).

As far as the refugee question is concerned, it was thrown under the bus as the administration advocated for a no-return solution. In the same respect, it cut US funding for the UNRWA. These constituted decisive policies never advocated before by the previous US administrations. Unilateralism was also manifested in other issues. The Trump administration took a set of additional decisions in an attempt to increase the pressure on the Palestinian Authority to come to the negotiating table with Israel. It closed the Palestine Liberation Organization office in Washington, and ended US aid to Palestinians, in both the Gaza Strip and the West Bank. To sum up, the adoption of unilateralism testifies to the abandonment of not only US past stances, but also international consensus regarding some of the most complicated issues in the Israeli-Palestinian conflict. As a result, the Trump decisions could hinder genuine peace prospects of a two-state solution in the future. 


\subsubsection{The rationale behind the Trump administration disregard of international institutions and norms}

The administration perceived international institutions as not conducive neither to the American interests nor to any realistic solution to the Israeli-Palestinian conflict. Equally disturbing for the Trump administration, the UN bodies discriminate against Israel, its closest ally in the region. Therefore, it took the international constraints out of its equation and let its foreign policy be driven purely by its own national security considerations. The Trump administration's neglect to address global issues through international institutions emanates from its espousal of what the administration termed "principled realism" and its promotion of the notion of “sovereignty". Powaski (2019, p. 247) argues that the 2017 National Security Strategy stresses the pursuit of the US national interests and that the best way to protect them is not through the conventional international institutions, but rather through inter-state sovereign relations. For Powaski, the strategy "acknowledges the centrality of power in international politics", ergo the emphasis of the Trump administration on the importance of the Realist school in international relations.

Ettinger (2020) expounds on the administration's emphasis on the need to respect US sovereignty. The Trump administration incarnates "populist sovereignty" (p. 411) in the sense that it is the moral duty and responsibility of the administration to protect the American nation and preserve its interests, regardless of the international constraints. In this respect, stressing the need to fully embrace sovereignty falls in line with the underpinnings of the Jacksonian school of American foreign policy which does not show any restraint in slashing international commitments that curtail US freedom to defend its interests. Ettinger indicates that 
President Trump's speeches, in addition to the 2017 National Security Strategy, are illustrative of the "fidelity to popular sovereignty and the conservative case for rejecting international law and governance" (p. 423). This is also affirmed by Cha (2016). In the same vein, Ashbee and Hurst (2019) corroborate that the National Security Strategy, which holds international cooperation in suspicion, stressed the idea of competition between nations with the term "competition" (p. 10) employed eighteen times. Yet Ettinger notes that the US rejection of international institutions is not something new. He recalls how the US Congress, in the 20th century, firmly rejected the US participation in the League of Nations and that such a decision was "driven by concerns over international restrictions on American freedom of action" (p. 423). In a nutshell, the Trump administration defended its sovereign right to act in the best interest of the US even if it was at the expense of US international commitment and norms.

\subsection{Triggering geopolitical transformation: An Arab-Israeli security alignment} to confront Iran's quest for regional hegemony

As the US continues to disengage from the region, the Trump administration embarked on a strategic shift in the American foreign policies towards Iran and the Israeli-Palestinian conflict to catalyze a geopolitical transformation in the region. This resulted in laying the ground for an Arab-Israel security alignment to better balance against Iran's growing influence. The chapter is divided into two main sections. In the first section, I apply the strategic shift of Trump-era American foreign policy on Ryan's three variables behind the Arab-Israeli alignment. In the second section, I discuss the geopolitical implications of Trump-era policies. Firstly, I outline the 
features of this potential Arab-Israeli security alignment. Secondly, I showcase how the geopolitical struggle could raise tensions in the Persian Gulf.

\subsubsection{Application of Ryan's three variables on the Trump administration's approach to the Arab-Israeli alignment.}

According to Ryan's 'regime security' theory $(2009,2015)$, there are three variables that could put the security of the Arab regimes at risk: 'domestic security', 'political economy', and 'external security'. To ensure their security, Arab regimes tend to shift their external alignments. In attempting to apply Ryan's theory to the study, I found 'external security' as the most pressing variable that the Trump administration played into to push for the Arab-Israeli alignment. This was followed by the 'political economy' variable, with no reference to the 'domestic security' variable at all. I suggest Ryan's framework as informative theoretical lenses through which the Trump administration's approach towards the American foreign policy in the Middle East could be explored.

\subsubsection{The 'domestic security' variable}

This factor was not identified in the data findings. Results did not reveal that the Trump administration nor the Arab leaders addressed domestic threats to their regimes. However, the Arab-Israeli alignment helps the Arab rulers to maximize their internal security. In other words, domestic security could benefit from the alignment decision with Israel and did not cause it, according to my corpus findings. Ryan maintains that Arab alignment choices have "domestic consequences, often bolstering existing authoritarian systems and thwarting hope for greater domestic change (2015, para. 9). Accordingly, to fortify their regimes from internal threats, the Arab regimes 
could benefit from alignment with Israel to strengthen their security apparatus. Given that technological cooperation is stipulated in the Abraham Accords, the Gulf regimes could take their existing cooperation with Israel in this field to a higher and more sophisticated level. In this respect, not only counter-terrorism efforts could flourish, but also repressing critics and opponents could also intensify. There is already a litany of reports that state that Israel has provided GCC states with highly sophisticated surveillance technology that they use to spy and crack down on political dissidents (Bergman, 2016; Mazzetti et al., 2019; Zilber, 2019). Regarding the UAE, it could make most of the Israeli expertise in the field of technology so that it tightens its grip on the opposition voices, especially the Muslim Brotherhood-affiliated activists, that were emboldened by the Arab Spring under the watch of the Obama administration. The same applies to Bahrain. It could benefit tremendously from the technological prowess of Israel to purchase surveillance software and devices to stifle the Shia opposition groups that led the 2011 uprising and continue to represent a domestic threat to the Al Khalifa regime. In short, by aligning with Israel, Arab regimes could benefit from the Israeli technological know-how to fend off internal security threats, even though the 'domestic security' factor was neither raised by the Arab leaders nor explored by the Trump administration according to my corpus results.

\subsubsection{The 'political economy' variable}

For many Arab regimes, Israel represents a potential economic partner to diversify and boost their economies. For its part, the Trump administration capitalized on the 'political economy' factor. The most illustrative case was Sudan. It is mired in a deep economic crisis and critically needs to relieve its ballooning debts. It also 
suffers from social unrest. Thus, the US decision to remove Sudan from the State Sponsors of Terrorism list represented an incentive to align with Israel. This helped Sudan lift the US sanctions and put an end to three decades of international isolation. Indeed, in announcing the normalization of relations between Sudan and Israel on October 23, 2020, President Trump remarked that Sudan's peace agreement with Israel will "end Sudan's long isolation from the world". Moreover, both the United States and Israel will help Sudan unlock its economic potential by helping it "restore Sudan's sovereign immunity and to engage its international partners to reduce Sudan's debt burdens", a joint statement released on October 23, 2020, affirmed. Furthermore, Israel launched economic and trade relations with Sudan with a particular focus on agriculture, so important for food security in Sudan. In a nutshell, the 'political economy' determinant, including foreign aids, investment, and the need for social stability, seems to be instrumental in pushing Sudan to align with Israel, a factor the Trump administration capitalized on to approach the Israeli-Sudanese alignment.

As for the GCC regimes, economic diversification is vital to overcome the existing economic challenges as recommended by the International Monetary Fund (IMF). On the prospects of the oil sector in the Middle East, the latter released a study in early 2020 entitled The Future of Oil and Fiscal Sustainability in the GCC Region. In it, Mirzoev et al. (2020) alert the Gulf Cooperation Council to the probability that "global oil demand could peak as early as $2030 "$ (p. 12) due to the increasing use of renewable energy and the growing danger of climate change, among several other factors. Thus, they recommend that the six GCC member states embark on and accelerate the deep economic reforms which would be necessary to eschew an 
economic crisis. Mirzoev et al. warn that "the region's aggregate net financial wealth, estimated at $\$ 2$ trillion at present, would turn negative by 2034 as the region becomes a net borrower" (p. 21). Given that an oil crisis is in the offing, it is crucial for the Gulf regimes to find new alternative ways to avoid a multidimensional economic crisis, hence, the importance of forging economic ties with Israel. In light of their sensitive nature as 'rentier' states, ensuring strong economies will help the GCC regimes better address social dissatisfaction and navigate popular demands for political reforms especially after the recent waves of the Arab Spring.

In the same vein, Ferziger and Bahgat (2020) point out that the GCC states could tremendously benefit from cooperation with Israel in the field of agriculture. Israel has also one of the most creative and advanced projects in water-management and irrigation fields, both sectors the GCC states need to cultivate given the scarcity of water in these countries. Jones and Guzansky (2017) point out the continuity of Arab-Israeli cooperation in such fields even in times of diplomatic ruckuses. They state that even though Oman closed the Israeli trade office that it had opened in 1996, it continued to welcome Israeli scientists to the Middle East Desalination Research Centre (MEDRC) located in Muscat to tackle the water scarcity from which the region suffers.

To conclude, as demonstrated in the corpus findings, the Trump administration stressed that forging and nurturing economic cooperation with Israel will help the Arab regimes upgrade their economic sectors, thus helping them generate more economic growth and prosperity. The Arab regimes may find it strategic to cooperate with Israel in a variety of fields ranging from energy, trade, water, to agriculture, 
health, etc. This was evident in the bilateral peace deals of the Abraham Accords. Hence, the threat of social discontent, which swept the Middle East in the last decade, that could put the legitimacy of the Arab regimes in jeopardy, could be minimized. This attests to the relevance of Ryan's variable of 'political economy' in the normalization of ties between the Arab regimes and Israel and how the Trump administration approached this important factor. In fact, to facilitate economic cooperation and the establishment of full diplomatic relations between the Arab regimes and Israel, the Trump administration pursued a top-down "outside-in" approach towards the Israeli-Palestinian conflict as previously discussed. That was why the Trump approach constituted a strategic shift in the American foreign policy in the Middle East.

\subsubsection{The 'external security' variable}

According to Ryan, when faced with external threats, regimes tend to reorient their foreign policies by forging new alignments or realignment. UAE and Bahrain serve as two cases in point. Both are aligning with Israel to confront the external menace posed by Iran and its proxies across the Middle East. To put things into perspective, over the last two decades, the Iranian regime has tremendously benefited from the unstable situation in the Middle East. It took advantage of a post-invasion Iraq marked by inter-sectarian rifts, an Arab Spring that sent shockwaves across the region, and civil wars in Syria and Yemen to consolidate its influence in the Arab world (Dazi-Héni, 2020). In fact, in 2014, Ali Reza Zakani, an Iranian Member of Parliament, close to Supreme Leader Ali Khamenei, proclaimed: “Three Arab capitals have today ended up in the hands of Iran and belong to the Islamic Iranian revolution" 
adding that "Sanaa has now become the fourth Arab capital that is on its way to joining the Iranian revolution” (The Middle East Monitor, 2014, para. 1). Azodi (2020) mentions that certain Iranian officials acknowledge that Iran's growing foreign activities instilled fear and terror in the Arab states and drove them to seek a security umbrella in Israel. She cites the tweet of Ali Motahari, a former Iranian MP, who writes:

Aside from Emiratis' treacherous act, we also deserve some blame. We have scared the Arabs and pushed them towards Israel. An example of this is storming the Saudi embassy and setting it ablaze. The policy of making Iran the enemy has been fruitful. This needs to be remedied. (para. 5)

As previously discussed, Iran and its allied groups have been systematically demonized by the Trump administration which depicted them as an existential threat to the external security of the Arab regimes. The Trump administration tapped into the fears of the US regional allies of rapprochement with Iran. It alerted them to the grave danger of once again appeasing the Iranian regime by repeating the same colossal mistakes of the Obama administration should they think to engage with Iran. The Trump administration strategically burnt bridges between the Arab regimes and Iran while building ones with Israel. It persistently worked to entrench the perception that the underlying external security threat facing the Arab regimes emanated from no other sources other than Iran and its proxies while pushing the Arab regimes to rethink their stance towards Israel. Focusing on the convergence of interests between the Arab states and Israel helps the US administration deepen the negative perception about Iran while promoting a positive image of Israel. The Trump administration 
tends to lock the Arab states into existential binary views-Iran as a destructive and revisionist regime and Israel as a status quo power and multi-dimensional potential partner. The stance of the Former Minister Anwar Gargash came to prove the development of the negative perception of the Iranian regime. In an interview with the Associated Press, he remarked that the decades-long Iranian aggression in the region has pushed the Arab states to rethink their perception of Israel (cited by Lederer, 2020). The Trump administration seemed to have capitalized on that perception.

In a nutshell, branding the Iranian regime as the arch-enemy of the Arab regimes and Israel was hoped to drive them closer to each other to form a security alignment that fends off the Iranian threat. By demonizing Iran and maintaining the confrontational campaign of "Maximum Pressure", the Trump administration proved that Iran and its proxies remain perceived as the real external threat to the security of the Arab regimes, despite the dangerous rapprochement previously pursued by the Obama administration. That was why the "Maximum Pressure" constituted a strategic shift in the American approach towards Iran.

To conclude, my interpretation suggests that the Trump-era foreign policies towards Iran and the Arab-Israeli conflict were approached based on the 'external security' and 'political economy' variables suggested by Ryan's 'regime security' theory. In fact, as illustrated in the corpus findings, the "Peace to Prosperity" plan nicely encapsulates how these two factors were portrayed by the Trump administration as the main two sources of threat to the security of the Arab regimes. It says: "the State of Israel is not a threat to the region whatsoever. Economic conditions and Iran's malign activities, however, posed an existential threat to many of the 
region's states". It also stresses that "Integrating Israel into the region will allow it to assist across a wide range of economic challenges as well as counter the threats of Iran". In a strategic shift from the previous US approaches to both questions, the Trump administration engineered a GCC-Israeli security alignment that would help the US rely more on regional allies in confronting regional threats as it recalibrates its involvement in the Middle East.

\subsubsection{Implications of Trump-era policies on the geopolitical landscape}

By demonizing Iran, through the confrontational "Maximum Pressure" campaign, and bridging the gap between the Arab states and Israel, through a topdown approach, the Trump administration triggered a transformation in the geopolitical landscape in the Middle East. In what follows I enlist the different aspects of the possible security alignment between the Arab regimes and Israel. I also discuss how tensions in the Persian Gulf may heighten as the Arab-Israeli security alignment materializes.

\subsubsection{Prospects of an Arab-Israeli security alignment}

Throughout its tenure, the Trump administration worked towards pushing the GCC regimes to align with Israel to face the region's most pressing issues. It rallied the GCC rulers to form a security alignment with Israel that collectively confronts the Iranian threat to their regimes. Of particular importance was how President Trump, in his first trip abroad to the Middle East, signaled that the US will not fight its allies' enemies on their behalf. President Trump noted: "But the nations of the Middle East cannot wait for American power to crush this enemy for them. The nations of the Middle East will have to decide what kind of future they want for themselves, for 
their countries, and for their children". Added to that, President Trump expressed his intention and did indeed scale back US presence in the Middle East by bringing back home US troops from Syria, Iraq, and Afghanistan. This implied that the US allies needed to rethink their traditional reliance on the US for security and stability in the region in the long run. Wechsler (2019) remarks that such declarations did nothing but push the Middle Eastern regimes to seek a new security architecture that fills the void caused by the US retrenchment.

Alternatively, the Trump administration, in a visionary and strategic departure from the past administrations' approaches, spurred a geopolitical transformation in the Middle East. It bridged the gap between the Arab regimes and Israel by portraying Israel as a potential partner and demonizing Iran and its allied groups as the common threat to the region. As Arab regimes continue to jump on the train of normalization, new security Arab-Israeli alignments are bound to emerge and take shape, so strategic to balance against Iran and its proxies in the future. My findings illustrated that the normalization of relations between the Arab regimes and Israel will not likely stop at the transactional and business level, it will cultivate strategic multi-dimensional cooperation, most notably at the security level, so beneficial for both parties in the long term. In this respect, in an interview with the Associated Press, Anwar Gargash, former Minister of State for Foreign Affairs urged the Israelis to think strategically about the normalization of relations between Israel and UAE. He said:

The only thing I want to say is the more strategic the Israelis look at these relationships, the more doors will open to them...If they look at it very 'transactionally', I think that it is not going to send a very good omen for 
normalizing relations with many of the Arab countries. (as cited by Lederer, 2020, para. 3)

A few days after normalizing ties, according to the official Emirati News Agency (WAM), Mossad director Yossi Cohen visited UAE to discuss "cooperation in the fields of security" (para. 2) with the UAE's national security adviser Sheikh Tahnoun bin Zayed Al Nahyan (Al Jazeera, 2020). The fact that Cohen was the first Israeli official to pay a visit to UAE, in addition to the security talks, echoes the importance and significance of security cooperation between the two states. In light of the security cooperation underscored in the Abraham Accords, it comes as no surprise that UAE and Bahrain, and perhaps later the rest of the GCC states, agreed to open their ports, airspace, and territories to Israel. While this may take several forms, increased security cooperation signals an alignment between the Arab regimes and Israel. I adopt the term alignment, rather than alliance, because the former is less formal than the latter. Drawing on Snyder's (1991) work in “Alliances, Balance, and Stability", Ryan (2009) explains that alliances are formal and mutual "promises" between states in the field of security and defense such as NATO and the Warsaw Pact noting that beyond the Western world, such alliances hardly succeeded. Accordingly, Ryan defines alignment as "an informal relationship between two or more states, involving expectations of political and economic support that may include, but is not restricted to, security affairs" (p. 5). In what follows, I discuss how different forms of security arrangements come into play to undergird the Arab-Israel security alignment triggered by the strategic shift of the Trump-era foreign policies.

First, regarding the Israeli presence on the GCC soils, Azodi (2020) suggests that the GCC states may invite Israel to establish a military presence on the southern 
shores of Iran. Similarly, Jadeh Iran (2020), an online website focusing on Iranian affairs, published an Iranian report alerting the Iranian government to the secret aims of the UAE-Israel peace agreement which were "clear in the geopolitical sense" (para. 2). These "undeclared aims" could "lead to the establishment of Israeli military and security bases facing Iran" (para. 1), thus moving Israel closer to the Iranian territories (as cited by The New Arab Staff, 2020b).

Second, concerning the security of the waterways, Israel may increase its cooperation with the GCC states to better protect their border and maritime activities. More protection would be provided for navigation freedom as GCC-Israeli cooperation would better control maritime shipping routes, thus thwarting the influence of the Islamic Revolutionary Guard Corps Navy (IRGCN) on those areas. In this regard, Dazi-Héni (2020) confirms that "The Abraham Accords undoubtedly mark a new departure in the region's geopolitics" since it "allow[s] Israel unprecedented access to the Arabian Peninsula and the Persian Gulf" (p. 6).

Third, as far as cooperation in the airspace is concerned, it is likely that Israel will use the airspace of the GCC states to strike Iran in case of a serious clash. Totten (2016) recalls how Saudi Arabia sided with Israel, albeit implicitly, against Hezbollah in the 2006 war. Thus, he expects it, in a scenario of a military confrontation with Iran, to allow the Israeli air force to use its air space to attack Iran's nuclear sites following an ancient Arab proverb: "the enemy of my enemy is my friend" (p. 31). Saudi Arabia already allowed Israel to use its airspace for commercial flights to UAE following the establishment of diplomatic ties between Israel and UAE as lauded by Jared Kushner. 
Fourth, in light of the importance of the security cooperation in the Abraham Accords, conducting joint military drills would certainly be among the potential areas to test military cooperation between the Arab states and Israel. Bowman and Nagel (2020) suggest that Israel could join the formidable yearly Iron Union military exercise between the US and UAE and described it as a "promising opportunity" (para. 10) in the field of military cooperation. Further, the decision of the US Department of Defense to move Israel into the U.S. Central Command (CENTCOM) will also pave the way for more military exercises between the Arab states and Israel. Fifth, it is thanks to the Abraham Accords that investing in mutual defense looks closer and more feasible than ever between the Gulf states and Israel. Knights (2020) highlights how the Abraham Accords started to materialize in the military collaboration between the signatory parties. He points out the signals conveyed by Moshe Patel, head of the Israel Missile Defense Organization, on December 15, 2020, who expressed Israel's interest in collaborating with UAE and Bahrain to further develop the missile defense sector that Israel and the US already work on. Knights notes that accelerating cooperation in the defense field will help curtail "Iran's fastdeveloping missile, rocket, and drone forces" (p. 1). In this respect, Knights recommends that this collaboration "be expanded to Saudi Arabia, Qatar, and other states" which will facilitate the formation of "stronger regional coalitions" whose objective is to ensure the "defensive containment of Iran, as opposed to costly and destructive debacles like the Yemen war" (p. 1). He stresses that the US, Israel, and the Arab allies should double their efforts to address "the urgent need for greater defense capabilities" (p. 1), much needed to fill the gap in the defense systems of these states. Regarding the US, he observes that the US defense system came under 
enormous pressure from the rocket attacks fired last December 2020 into the American Embassy in Baghdad and warns that "If larger rocket salvoes are launched in the future, such defenses would be quickly overwhelmed" (p. 2). With regard to Israel, Iran-backed Hezbollah possesses “120,000-150,000 unguided and precision rockets", coupled with Iran's capabilities to launch "missiles and drone attacks" from its territories, Syria, and Iraq, all constitute a challenge to the Israeli defense system. The same applies to the UAE which was and still is a potential target of the Houthis (p. 2). Besides, Iran has invariably asserted that UAE would be a legitimate target of its wide range of weapons. Similarly, Knights recalls how Saudi Arabia suffered from the constant Houthi attacks, but also assaults from the Iranian and Iraqi territories, on its capital, southern towns, and vital economic facilities, most dangerous of which was the Abqaiq attacks in 2019 which paralyzed oil production for a couple of weeks.

Knights recommends that defense systems be less expensive and more efficacious by mobilizing the necessary resources and capabilities that the US allies enjoy. He maintains that Israel has considerable hands-on experience in developing and operating missile defense systems such as the Iron Dome system used to defend its territories. Regarding the Gulf states, Knights views that they "are well-positioned to surveil launch areas in Iran and Yemen that Israel cannot easily monitor" (p. 3). In a nutshell, one can notice that investment in the defense systems looks appealing for all parties and represents a win-win opportunity to better protect their states from the threats emanating from Iran and its proxies in the region.

Sixth, it goes without saying that the Abraham Accords will open the doors for Israel to collect extensive information on Iranian activities, especially in the Persian Gulf. This, in turn, will enhance the exchange of intelligence between not only the 
UAE and Bahrain, and Israel, but also the remaining GCC states. Rabi and Mueller (2017) argue that, for instance, intelligence between Saudi Arabia and Israel intensified in the last decades. In their words: "the invasion of Iraq in 2003 gave rise to unprecedented levels of tacit security and intelligence cooperation between Israel and Saudi Arabia" (p. 576). In the same vein, the online Iranian newspaper Jadeh Iran (2020) states that the establishment of diplomatic ties between Israel and UAE puts the national security of Iran in jeopardy as the majority of Iran's ports, oil facilities, and nuclear sites are located in the Gulf coast. The report claims that, given the geographic proximity of the UAE, the peace agreement would provide Israel with an “eye, and perhaps even a hand as well, a few kilometers away from strategic Iranian installations" (as cited by The New Arab Staff, 2020, para. 7).

Seventh, cooperation in the security field with the new anti-Iran coalition could help the US further share the security burden with its allies and partners consistent with its retrenchment strategy in the region. Knights (2020) remarks that "Despite their recent economic challenges, these [Gulf] states are still quite wealthy and could offset some of the \$3-4 billion in missile defense research and development costs that the United States undertakes each year" (p. 3).

Eight, technology is just another field in which the Arab states could benefit enormously from Israel to maximize the security of their regimes. There is no doubt that Israel enjoys unparalleled technological progress in the Middle East. Given that it is the leading power in technological innovation, as underscored by Ferziger and Bahgat (2020), the Gulf states do not wish to miss the opportunity to strike a partnership with Israel to enhance their security apparatus, particularly in the cyber field. The Economist Intelligence Unit (2018) unravels the concerns and 
vulnerabilities of the GCC states in protecting themselves against the mounting malicious cyber activities that target both their public and private sectors. It maintains that the magnitude of cyber attacks on the GCC states reflects the daunting cybersecurity challenges and the need to invest in this field particularly for Kuwait, Bahrain, and Saudi Arabia. Zilber (2019) affirms that "Over the past decade, growing military threats from Iran, its proxies, and Sunni jihadist groups like the Islamic State pushed Israel and the Gulf states into even closer security cooperation" (p. 1-2), most notably in the cyber security field.

Ryan's $(2009,2015)$ 'regime security' approach seems to be yet again insightful when it comes to understanding the Arab-Israeli security alignment affected by the Trump administration. As underscored by Ryan (2009, p. 14), "Alignments are external solutions to both domestic and regional security problems". Ryan's approach proved it has considerable empirical grounds in my research findings and analysis. It helps explore how the Trump-era foreign policies triggered a geopolitical transformation in the Middle East through the alignment of the GCC regimes with Israel. When these regimes externally align with Israel, this could be beneficial at the domestic and regional levels. Domestically, they could benefit mostly from the new economic ties with Israel to better diversify their political economy. In addition to that, they could benefit from Israel's technological prowess to surveil and silence political opposition, so important for the stability of their regimes. Regionally, they could better confront the external threat of Iran and its allied groups. Thus, it could be inferred that a 'regime security' approach may have shaped the shrewd shift in Trump-era foreign policies towards the Middle East. 
Whilst Odeh (2020) is right to argue that the transformations the Middle East is witnessing "was facilitated by the weakening of former giants" (para. 6) such as Egypt and Iraq, my research findings suggested that the Trump administration embarked on a strategic shift in the American foreign policy that also led to this burgeoning security alignment against Iran. This was evidenced; first, in one of the pillars of the "Maximum Pressure" campaign as it aimed to "revitalize our [the US] traditional alliances and regional partnerships as bulwarks against Iranian subversion". Second, the "Peace to Prosperity" plan aimed at bridging the gap between the Arab states and Israel by emphasizing that "previously unimaginable opportunities and alliances are emerging", so important to confront the threat posed by Iran.

Equally important, my findings and analysis are consistent with Totten's (2016) claim that, to the surprise of so many, the Arab Sunni states are aligning with Israel to confront Iran. They are also consistent with Azodi's (2020) argument that claims that the burgeoning alliance between the Arab states and Israel can potentially alter the balance of power in the region in favor of the US and its allies. Further, Odeh's (2020) view lends support to my analysis of the relevance of Ryan's regime security approach. She underscores that UAE is bent on upending the influence stemming from both the Muslim Brotherhood as well as the Iranian regime. To achieve its aims, UAE rulers opted for alignment with the US and Israel to strengthen the fortress of their regimes against what they perceive as internal and external security threats. She writes: "The priorities of Mohammed bin Zayed (MBZ) were clear: confront Iran and crush the Muslim Brotherhood and do it by allying with the US and Israel" (para. 12). 
Guzansky and Marshall (2020) confirm that the insecurity of the Gulf regimes is "a motivating factor" (p. 382) in reaching the Abraham Accords. For them, a number of reasons pushed these states to reconsider their political and strategic calculations. First, the Gulf states were concerned that, in case Biden was selected, a new administration would "implement much stricter policies than the Trump administration regarding human rights and regional arms transfers", in addition to the possibility of taking "a softer approach on Iran" (p. 382). Second, these Gulf states put "the continuation of America's commitment to regional security" (p. 382) into question at a certain point, mainly due to the retrenchment policies of both the Obama and Trump administrations. Third, the deep division among the Palestinians continues to reverberate across the Arabian Peninsula in terms of who should be supported, Gaza under the control of Hamas or the West Bank under the control of the Palestinian Authority. Fourth, the need to confront the growing Iranian threat constitutes a common denominator between some of the Arab states and Israel. For Guzansky and Marshall, "the Accords underscore the lengths to which some Arab states are willing to go to counter Tehran's increased regional aggression and influence" (p. 382).

Allied with Ryan's framework of 'regime security' is the thesis put forward by Jones and Guzansky (2017) who argue that Israel and Gulf Arab states yearn to jointly form what they call a "Tacit Security Regime" (TSR) (p. 399), driven mainly by the desire to curb Iran's growing threat in the region yet without compromising the internal political constraints. An openly explicit alignment with Israel might be domestically costly for certain regimes, thus working behind closed doors would be more efficient not only to fend off mutual threats to security, emanating from Iran and 
its proxies but also to expand cooperation in different fields. Jones and Guzansky maintain that Israel and the GCC states face three core challenges: Iran's growing destabilizing behavior, which constitutes "The dominant variable that has pushed the Gulf states and Israel toward a TSR", radical jihad, and American disengagement from the region. The construct of the TSR, in the eyes of its theorists, draws on two underpinning tenets. The first one is that geographical proximity is not deterministic of the in-depth cooperation between Israel and the GCC states. The second one is that this TSR is essentially based on a mutual "shared perception of threat" (p. 407), that is confronting the Iranian menace, and not other inter-state issues. While the "Tacit Security Regime" appears to materialize thanks to the Abraham Accords and the UAE-Bahrain-Israel alignment, one observes that the Trump-era normalization of ties between the Arab states and Israel did not spark domestic opposition as Jones and Guzansky may have expected. Indeed, Fiore (2020) states that there are "clear signs of an atmosphere for a warm peace developing: Bahrainis, Emiratis, and Israelis are excited about their joint peacemaking project" (p. 2), to the contrary of what was anticipated by Jones and Guzansky in terms of domestic opposition.

For its part, given the burgeoning Arab-Israeli security alignment, Iran is expected to further strengthen its "Axis of Resistance", but also to look for other allies. Here, it may turn for Turkey as a strategic ally. Indeed, Azodi (2020) suggests that normalization of ties between Israel and UAE may push Iran towards Turkey which, in its turn, was scathingly critical of the UAE decision. She points out that Turkey has had strained relations with Saudi Arabia, Israel, and even the US. Regarding Saudi Arabia, Turkish relations with the kingdom further plummeted with the Saudi assassination of journalist Jamal Khashoggi. For his part, Saudi Crown 
Prince went as far as to include Turkey in the "contemporary triangle of evil" (para. 7) along with Iran and its proxies in the region. In relation to Israel, at the time of her writing, Azodi is right to mention that Turkey does not have an Ambassador in Israel. Indeed, Turkey's diplomatic feud with Israel heightened in 2018 following Israel's "deadly attacks" on the Gaza Strip. It is worth remembering that Turkish-Israel diplomatic ties were particularly severed in 2010 following Israel's attacks on the Turkish flotilla while on its way with aid to Gaza. Yet more recently, in December 2020, Turkey appointed a new ambassador (A1 Jazeera, 2020, para. 2). With regard to Turkish-US relations, the US vehemently opposed Turkey's plan to purchase the S400 Russian air defense systems (Azodi, 2020).

In light of this multifaceted security cooperation, some scholars and analysts expect the Arab-Israeli alignment would result in a more formal formation of an Arab Sunni-Israeli coalition or alliance as suggested by (Azodi, 2020; Knights, 2020; Odeh, 2020; Totten, 2016). As shown in the corpus results, the Trump administration itself used the terms "coalition" and "alliance" several times. Yet while this has not officially seen the light yet, one should note that the past experiences of the Arab attempts to forge formal alliances or coalitions were not successful, to say the least. The experience of what Walt describes as an "ill-fated" Baghdad Pact in 1955 attests to the limits of alliance formation in the Arab world. The alliance consisted of Iraq, Turkey, Pakistan, Iran, Great Britain, and the US and aimed to contain the influence of the Soviet Union. Yet the pact was faced with sheer resistance from certain Arab states, especially Egypt (Walt, 1987, p. 58). Under the Trump administration, in April 2019, the US announced the Saudi-led initiative of creating the Middle East Strategic Alliance (MESA). The latter aimed to build a security alliance between the Gulf 
Cooperation Council, Jordan, and Egypt. While some regarded it as an 'Arab NATO', Mick Mulroy, the former deputy assistant secretary of defense for the Middle East, commented that MESA is not similar to NATO in that there is no 'Article 5' which states that member states will defend other NATO members if they are attacked. He explains that MESA will help the US work closely with the GCC +2 on stabilizing the region (Lopez, 2019). Indeed, MESA could be regarded as a US effort to contain Iran in the region, although the alliance has not yet been formalized given the past rifts in the GCC, the boycott of Qatar, and the divergent views of these countries on a litany of issues in the Middle East. It should be noted both Oman and Qatar are already not antagonistic to Iran. Equally important, Egypt has already pulled out from the talks due to the lack of vision of the MESA which raises serious questions about the prospect of such an alliance (Kalin \& Landay, 2019). In a nutshell, Ryan $(2009,2015)$ is right to maintain that the Arab system of alliance is quite different from the Western experience as the empirical reality illustrated with the past experiences. Yet given the demonization of Iran and the mobilization of US allies against it, the Trump administration may have strengthened the security alignment between the Arab states and Israel to unprecedented levels of security cooperation.

\subsubsection{The Persian Gulf as the geopolitical ring}

As a result of the Arab-Israeli security alignment, the geopolitical struggle in the Persian Gulf will likely mount between the anti-Iran Arab regimes, the US, and Israel, on the one hand, and Iran and its proxies, on the other. On January 15, 2021, the Defense Department announced that it will move Israel from the European Command (EUCOM) to CENTCOM. In clarifying the rationale behind such a change, the Pentagon declared that the US-brokered Abraham Accords brought about 
"a strategic opportunity...to align key U.S. partners against shared threats in the Middle East” (as cited by Orion \& Montgomery, 2020, para. 1).

In light of the GCC-Israeli security alignment and the recent rearrangement of CENTCOM, anti-Iran Arab regimes would move closer than ever to Israel. The latter could kill two birds with one stone. First, it would build stronger relations with the Arab states that have already normalized ties with them. Second, it could move closer to the ones that still reject it. That is, it will be a golden opportunity for Israel to normalize militarily with the rest of the Arab regimes under the umbrella of CENTCOM. The decision by the Trump administration to move Israel into CENTCOM was undoubtedly illustrative of the geopolitical changes taking place in the Middle East. In addition to that, since its national security is now in peril, it is expected that Iran would take advantage of the Abraham Accords to justify its activities in the region (Ferziger \& Bahgat, 2020; Guzansky \& Marshall, 2020). Indeed, Iran's concerns will heighten in the face of increased security cooperation between the new partners in the region.

Azodi (2016) states that the Persian Gulf has historically played a pivotal role in the national security of Iran. Its strategic importance, in addition to the historical aspect, emanates from Iran's costly wars of the past. Iran learned from its mistakes during its war with Iraq in the 1980s, in that the Arab Sunni states will most likely side with any Arab adversary facing Iran, “Therefore, Tehran's security calculations, controlling the waterway is existential to Iran's security" (para. 2). Drawing on the importance of the Persian Gulf, no wonder then that Iran embarked on sweeping reforms in its naval forces to best deal with any threat to its Persian shores, Azodi remarks. 
Furthermore, the Persian Gulf is vitally important for the Iranian economy. Most of Iran's oil exports pass through the Persian routes in addition to the fact that some of Iran's major oil facilities are situated along the Persian shores. Equally important, the Persian Gulf represents the sole "buffer zone" (para. 3) that shields Iran from its southern Arab Sunni states with which Iran has been historically at odds. Moreover, in case of a full-scale war, Iran's control over the Persian Gulf will give it greater leverage should a serious confrontation erupt. Iran has frequently threatened to block the Strait of Hormuz in an attempt to show that it could "shock the international oil markets by disrupting the shipment of oil from the region" (para. 3). Last but not least, Azodi stresses that identity politics play a key role in managing the Persian Gulf for the Iranians. The Persian character is asserted in the management of the waterway. This area is also protected by and under the control of the IRGCN which is, in its turn, under the control of hardliners that oppose any form of détente with the US. In this respect, Vaughan (2016) notes that hazardous incidents between the American forces and their Iranian counterparts doubled in 2016 (as cited in Azodi, 2016), let alone, one wonders, with the Israeli access to the area.

Overall, the Arab-Israeli security alignment revolutionizes the geopolitical setting in the Middle East. It also increases the likelihood of balancing against Iran and its proxies in the region. Given Iran's obsession with its hegemonic control of the Persian Gulf as well as its growing influence in the region, the competing powers in this body of water, and the broader region, are prone to more tensions, miscalculations, and accidents, especially if Israel establishes military presence in the Persian Gulf. 
Yet while Ryan's regime security appears to be illuminating in developing insights into how Trump's legacy affected geopolitical transformation in the Middle East, laying the ground for a strategic security alignment between the Arab states and Israel seems also to slightly fall in line with the recommendation of Mearsheimer and Walt (2016, p. 2) and Walt (2018, p. 14) to go back to a strategy of 'Offshore Balancing' in that the US should "pass the buck" to regional actors to maintain the balance of power in their region. In the words of Mearsheimer and Walt (2016, p. 2), "Washington should pass the buck to regional powers, as they have a far greater interest in preventing any state from dominating them”.

Drawing on the underpinnings of 'Offshore Balancing', my research demonstrated that the Trump administration partially set the stage for the return to this strategy. In addition to the fact that the administration reduced the number of US troops in Iraq, Syria as well as Afghanistan, it drew the Arabs states and Israel closer to each other and encouraged them to cooperate in bilateral and regional security affairs.

Similarly, the analysis put forward in this thesis research lends support to Yom's (2020) argument that the US is undergoing a hegemonic decline in the Middle East initiated by the Obama administration and sustained by the Trump administration. He expects that the US will adopt an 'Offshore Balancing'. Sharing the burden of checking Iran's growing influence with US allies will help the US continue to disengage from the Middle East and focus more on China. In fact, Yom is right to anticipate that the US will change its strategic posture in the region. The Trump administration rejected the Bush administration's 'Liberal Hegemony’ strategy in the Middle East and instead set the stage for the resort to 'Offshore Balancing' in 
the long term. It is the GCC-Israeli security alignment empowered by the Trump administration that helped paved the way for a more effective reliance on US allies in the region in the future. Finally, in line with my findings and discussion, Dazi-Héni (2020) views the rapprochement between the Gulf states and Israel as conducive to a "new geopolitical axis of Israel and the Gulf states" (p. 7) which the US hopes to be effective not only in countering Iran's influence but also in containing the Chinese penetration in the region. 


\section{Chapter Six: Conclusion}

This thesis examines Trump's legacy in the Middle East. In it, I argue that the Trump administration embarked on a strategic shift in American foreign policy which affected the geopolitical dynamics in the region. Firstly, I explore this shift that characterized the policies towards Iran and the Israeli-Palestinian conflict. I conclude that the "Maximum Pressure" campaign and the "Peace to Prosperity" plan were both distinct approaches marked with a heavy dose of unilateralism that defied sometimes international norms. Secondly, I also explore the implications of such policies on the geopolitical landscape in the region. I conclude that the strategic shift in Trump-era foreign policies engineered a potential security alignment between the GCC states (UAE, Bahrain, and Saudi Arabia, albeit secretly) and Israel as the US adjusts its commitment to the region.

My inferences are drawn from my empirical findings and evidence. I

conducted systematic research that analyzed a corpus representative of different genres of Trump-era foreign policy documents. I used Quirkos, a qualitative content analysis software, to code and categorize the data. To interpret the results, I applied Ryan's 'regime security' theory on the Trump administration's approach towards the Iranian and Israeli-Palestinian conflict.

Drawing on Ryan's 'regime security' theoretical framework, I found that the Trump administration tapped into the insecurity of the Arab regimes in the Middle East. It played into the 'external security' variable by demonizing Iran and pursuing a "Maximum Pressure" campaign. It also played into the 'political economy' factor by bridging the gap between the Arab regimes and Israel and encouraging economic cooperation between the two parties, hence the top-down "outside-in" approach to the 
Israeli-Palestinian conflict embodied in the "Peace to Prosperity" plan. Consequently, the Trump administration managed to push for a GCC-Israeli security alignment. This was implied in the security cooperation promoted in the Abraham Accords as well as in the actions and declarations of officials. Indeed, this could take the form of cooperation in the field of intelligence, military training, defense, energy, or still even the possibility of establishing Israeli military presence in the GCC states, for instance. Based on this potential multidimensional security cooperation, the Trump administration's approach and endeavors to sponsoring such an alignment were strategically important and in line with the US disengagement from the Middle East. Differently put, altering the geopolitical landscape may have facilitated the reliance on US allies to maintain the balance of power against Iran's growing influence in the region, and thus the possibility of returning to a strategy of "Offshore Balancing" in the long run. While the shift in the American foreign policy was a thoughtful approach crafted by the Trump administration, regional transformation was envisioned at the expense of Palestinian rights. This shift also provoked acts of "Soft Balancing" against the US on the world stage.

\subsection{Research Limitations}

Given the limitations of the Qualitative Content Analysis method, findings and discussion in this thesis may be prone to unintentional bias. Therefore, I first endeavored to make this research as systematic as possible by setting well-defined and clear criteria in the research Methodology. Secondly, I tried to support my findings with as much evidence as possible from the corpus which ended up somewhat in a long Results chapter. Thirdly, due to the magnitude of data, random sampling might have saved plenty of time in the coding of data and would have 
allowed more focus on the analysis and interpretation of data. Fourthly, the correlation between the Trump-era foreign policies towards Iran and the IsraeliPalestinian conflict may need to be approached quantitatively to prove the correlation suggested in my interpretation.

\subsection{Recommendations}

Given that Ryan's 'regime security' theory is based on insights into both international relations and comparative politics, it would be illuminating to study how the Arab regimes framed the external alignment with Israel to their people and which Ryan's variable was used the most by the regime elites. In other words, Ryan's framework could be further tested to examine how the Arab regimes approached their alignment with Israel. Further, in light of the strategic shift argument advanced in this thesis and given the lack of previous diplomatic experience by President Trump and scores of his appointees, most notably former Senior Foreign Policy Advisor Jared Kushner, it would be interesting to know how the "principal-agent problem" manifested itself and addressed when promoting and executing Trump-era foreign policies. In other words, researchers could investigate how the foreign policy establishment dealt with the way the Trump administration was strategizing concerning the most pressing and complicated issues in the Middle East: Iran's growing influence and the Israeli-Palestinian conflict. Moreover, since my data focused exclusively on public documents regarding the Trump-era foreign policies in the Middle East, researchers may find it interesting to investigate the internal dynamics of the Trump's team as far as the internal policy disputes were concerned. In particular to the Iranian question, it would be illuminating to scrutinize how the disputes between the dovish and hawkish foreign policy actors played out and how 
they affected the policy shift that marked American foreign policy towards the Iranian nuclear program. Last but not least, given that the Biden administration expressed its deep interest and willingness to revitalize the JCPOA, Turkey is developing warmer relations with Al-Sisi regime, and the Arab Quartet (Saudi Arabia, UAE, Bahrain, and Egypt) have already normalized ties with Qatar, it would be interesting to examine whether the Biden administration deems alignment politics very important in approaching American foreign policy in the Middle East as was the case for its predecessor especially with the fluid inter-state relations in the region. 


\section{References}

al-bab.com. (2002). The Arab Peace Initiative, 2002. https://al-bab.com/documents$\underline{\text { section/arab-peace-initiative-2002 }}$

A1 Jazeera. (2018, April 30). MBS: Palestinians should 'accept Trump proposals or shut $u p^{\prime}$. https://www.aljazeera.com/news/2018/4/30/mbs-palestinians-should-accepttrump-proposals-or-shut-up

Al Jazeera. (2020, August 18). Israel's Mossad spy chief visits UAE for security talks. https://www.aljazeera.com/news/2020/8/18/israels-mossad-spy-chief-visits-uae-for$\underline{\text { security-talks }}$

Al Jazeera. (2020, December 14). Turkey appoints ambassador to Israel after two years: Report. https://www.aljazeera.com/news/2020/12/14/turkey-selects-new-ambassador$\underline{\text { to-israel-report }}$

Al-Ubaydli, O. (2016, May 16). Iran's Threat to Block Hormuz: A Game Theory Analysis. LSE Middle East Centre Blog, LSE.

https://blogs.lse.ac.uk/mec/2016/05/16/irans-threat-to-block-hormuz-a-game-theoryanalysis/

Azodi, S. (2016, November 5). Iran, the Us, and the Persian Gulf. The Diplomat. https://thediplomat.com/2016/11/iran-the-us-and-the-persian-gulf/

Azodi, S. (2020, August 31). Why is Iran concerned about the peace agreement between the UAE and Israel? Atlantic Council. https://www.atlanticcouncil.org/blogs/iransource/why-is-iran-concerned-about-thepeace-agreement-between-the-uae-and-israel/

Arms Control Association. (2017, August). UN Security Council Resolutions on Iran. https://www.armscontrol.org/factsheets/Security-Council-Resolutions-on-Iran 
Ashbee, E, \& Hurst, S. (2020). The Trump foreign policy record and the concept of transformational change. Global Affairs (Abingdon, Oxfordshire, UK), 6(1), 5-19. https://doi.org/10.1080/23340460.2020.1734954

Erdoğan, A., \& Habash L. (2020). U.S. Policy Toward the Israeli-Palestinian Conflict under the Trump Administration. Insight (Türkey), 22(1), 125-146.

https://doi.org/10.25253/99.2020221.09

Azizi, H., Golmohammadi, V., \& Vazirian, A. H. (2020). Trump’s “maximum pressure” and anti-containment in Iran's regional policy. Digest of Middle East Study

(Milwaukee, Wis.), 29(2), 150-166. https://doi.org/10.1111/dome.12219

Bergman, R. (2016, September 8). How Israeli-made spyware made it to the Arab world. Ynetnews. https://www.ynetnews.com/articles/0,7340,L-4851719,00.html

BBC News. (2003, July 26). Bush criticises Israel fence. http://news.bbc.co.uk/2/hi/middle east/3096609.stm

BBC News. (2019, December 9). Six charts that show how hard US sanctions have hit Iran. https://www.bbc.com/news/world-middle-east-48119109

Ben-Meir, A. (2014, January 25). The Nuclear Deal: Netanyahu vs. Obama. HuffPost. https://www.huffpost.com/entry/the-nuclear-deal-netanyah_b_4338600

Blackwill, R. D. (2019). Trump’s Foreign Policies Are Better Than They Seem. Council on Foreign Relations. Retrieved from https://www.cfr.org/sites/default/files/report_pdf/CSR\%2084_Blackwill_Trump.pdf Bowman, B., \& Nagel, J. (2020, September 8). Why not add Israel to this year's US-UAE Iron Union exercise?. Defense News.

https://www.defensenews.com/opinion/commentary/2020/09/10/why-not-add-israelto-this-years-us-uae-iron-union-exercise/ 
Boys, J. D. (2021). All Change in the White House? Trump's Legacy and Biden's Challenges. Political Insight (Political Studies Association of the United Kingdom), 12(1), 29-31. https://doi.org/10.1177/20419058211001001

Brands, H. (2018). American grand strategy in the age of Trump. Brookings Institution Press.

Byman, D., \& Moller, S. B. (2016). The United States and the Middle East: Interests, Risks, and Costs. In J. Suri \& B. Valentino (Eds.), Sustainable Security: Rethinking American National Security Strategy (pp. 1-42). Oxford University Press. DOI:10.1093/acprof:oso/9780190611477.001.0001

Cha, T. (2016). The Return of Jacksonianism: the International Implications of the Trump Phenomenon. The Washington Quarterly, 39(4), 83-97. https://doi.org/10.1080/0163660X.2016.1261562

Clarke, M., \& Ricketts, A. (2017). Donald Trump and American foreign policy: The return of the Jacksonian tradition. Comparative Strategy, 36(4), 366-379. https://doi.org/10.1080/01495933.2017.1361210

Cook, S. A. (2020, October 28). Trump's Middle East Legacy Is Failure. Foreign Policy. https://foreignpolicy.com/2020/10/28/trumps-middle-east-legacy-is-failure/

Dazi-Héni, F. (2020, November 6). The Gulf States and Israel after the Abraham Accords. Arab Reform Initiative. https://www.arab-reform.net/wpcontent/uploads/pdf/Arab_Reform Initiative en the-gulf-states-and-israel-after-theabraham-accords 14899.pdf?ver=623241d1fde3dee17d2c959af2c2146d

Council of the European Union. (2018, May 9). Declaration by the High Representative on behalf of the EU following US President Trump's announcement on the Iran nuclear deal (JCPOA) [Press release]. 
https://www.consilium.europa.eu/en/press/press-releases/2018/05/09/declaration-bythe-high-representative-on-behalf-of-the-eu-following-us-president-trump-sannouncement-on-the-iran-nuclear-deal-jcpoa/

Deutsche Welle. (2019, March 26). Trump's Golan proclamation gathers international condemnation. https://www.dw.com/en/trumps-golan-proclamation-gathersinternational-condemnation/a-48070628

Doherty, C. (2020, May 31). A new perspective on Americans' views of Israelis and Palestinians. Pew Research Center. https://www.pewresearch.org/fact$\underline{\operatorname{tank} / 2019 / 04 / 24 / a-n e w-p e r s p e c t i v e-o n-a m e r i c a n s-v i e w s-o f-i s r a e l i s-a n d-p a l e s t i n i a n s / ~}$

Dueck, C. \& Takeyh, R. (2007). Iran's Nuclear Challenge. Political Science Quarterly, 122(2), 189-205. https://doi.org/10.1002/j.1538-165X.2007.tb00596.X

El-Khawas, M. A. (2005). Iran's Nuclear Controversy: Prospects for a Diplomatic Solution. Mediterranean Quarterly, 16(4), 20-41. https://doi.org/10.1215/10474552$\underline{16-4-20}$

Ettinger, A. (2020). Principled realism and populist sovereignty in Trump's foreign policy. Cambridge Review of International Affairs, 33(3), 410-431. https://doi.org/10.1080/09557571.2019.1659229

Fassihi, F. (2017, December 21). U.N. Vote Rebukes U.S. for Jerusalem Move. The Wall Street Journal. https://www.wsj.com/articles/u-n-vote-rebukes-u-s-for-jerusalem$\underline{\text { move-1513878035 }}$

Feith, D. J., \& Libby, L. (2020). How the Trump Plan Makes Peace Possible. Middle East Quarterly, 27(4), 366-379. https://www.meforum.org/middle-eastquarterly/pdfs/61460.pdf 
Ferziger, J. H., \& Bahgat, G. (2020, July 7). Israel's growing ties with the Arab Gulf states. Atlantic Council. https://www.atlanticcouncil.org/wpcontent/uploads/2020/07/Israel\%E2\%80\%99s-Growing-Ties-with-the-Gulf-Arab-

\section{$\underline{\text { States.pdf }}$}

Fiore, M. (2020, November 1). The Abraham Accords and the Palestinian Issue. EInternational Relations. https://www.e-ir.info/pdf/88442

Fitzpatrick, M. (2006). Assessing Iran's nuclear programme. Survival (London), 48(3), 526. https://doi.org/10.1080/00396330600905494

Fitzpatrick, M. (2015). Iran: A Good Deal. Survival (London), 57(5), 47-52. https://doi.org/10.1080/00396338.2015.1090123

Flanagan, J. C. (1954). The critical incident technique. Psychological Bulletin, 51(4), 327-358. https://doi.org/10.1037/h0061470

Frey, B. B. (2018). The SAGE Encyclopedia of Educational Research, Measurement, and Evaluation. SAGE Publications

Gingrich, N. (2017, May 24). The president just made a titanic foreign policy shift. The media missed it. The Washington Post.

https://www.washingtonpost.com/opinions/the-president-just-made-a-titanic-foreignpolicy-shift-the-media-missed-it/2017/05/24/405dfdda-3fcf-11e7-adba394ee67a7582 story.html

Gladstone, R. (2017, December 8). U.S. Faces Blunt Criticism at U.N. Over Jerusalem Decree. The New York Times.

https://www.nytimes.com/2017/12/08/world/middleeast/un-jerusalem-securitycouncil.html 
Goldberg, J. (2018, April 2). Saudi Crown Prince: Iran's Supreme Leader 'Makes Hitler Look Good'. The Atlantic.

https://www.theatlantic.com/international/archive/2018/04/mohammed-bin-salman$\underline{\text { iran-israel/557036/ }}$

Guzansky, Y., \& Marshall, Z. A. (2020). The Abraham Accords: Immediate Significance and Long-Term Implications. Israel Journal of Foreign Affairs, 14(3), 379-389. https://doi.org/10.1080/23739770.2020.1831861

Hassan, O. (2020). Crisis, narratives, and the construction of US-Middle East relations: continuity and change in world history and Trump's America First. Global Affairs (Abingdon, Oxfordshire, UK), 6(1), 121-141. https://doi.org/10.1080/23340460.2020.1745084

Heller, J. (2009, November 18). Obama criticizes Israel over settlement-building. Reuters. https://www.reuters.com/article/us-palestinians-israel/obama-criticizesisrael-over-settlement-building-idUSTRE5AH15I20091118

Jewish Virtual Library. (n.d.). U.N. Security Council: U.S. Vetoes of Resolutions Critical to Israel. https://www.jewishvirtuallibrary.org/u-s-vetoes-of-un-security-councilresolutions-critical-to-israel

Mearsheimer, J. J., \& Walt, S. M. (2016). The Case for Offshore Balancing: A Superior U.S. Grand Strategy. Foreign Affairs (New York, N.Y.), 95(4), 70-83 https://www.foreignaffairs.com/articles/united-states/2016-06-13/case-offshore$\underline{\text { balancing }}$

Jones, C., \& Guzansky, Y. (2017). Israel's relations with the Gulf states: Toward the emergence of a tacit security regime? Contemporary Security Policy, 38(3), 398-419. https://doi.org/10.1080/13523260.2017.1292375 
Kalin, S., \& Landay, J. (2019, April 10). Exclusive: Egypt withdraws from U.S.-led antiIran security initiative - sources. Reuters. https://www.reuters.com/article/us-usamesa-egypt-exclusive/exclusive-egypt-withdraws-from-u-s-led-anti-iran-securityinitiative-sources-idUSKCN1RM2WU

Katzman, K. (2021). Iran Sanctions. Congressional Research Service. https://fas.org/sgp/crs/mideast/RS20871.pdf

Al Ketbi, E. (2020). Contemporary Shifts in UAE Foreign Policy: From the Liberation of Kuwait to the Abraham Accords. Israel Journal of Foreign Affairs, 14(3), 391-398. https://doi.org/10.1080/23739770.2020.1845067

Knights, M. (2020, December 30). A Missile Defense "Manhattan Project" in the Middle East. The Washington Institute. https://www.washingtoninstitute.org/pdf/view/16403/en

Lederer, E. M. (2020, September 25). UAE: Iran's aggressive policies made Arabs look at Israel. AP NEWS. https://apnews.com/article/bahrain-israel-iran-united-arab$\underline{\text { emirates-united-nations-general-assembly-f2f7971130d3c64286e4d7f791e064ad }}$

Lindsay, J. M., \& Daalder, I. H. (2003). America Unbound: The Bush Revolution in Foreign Policy. Brookings Institution Press. https://doi.org/10.7864/j.ctt1gpcdnd

Lopez, T. C. (2019, April 30). Middle East Strategic Alliance Effort Aimed at Stabilization. U.S. Department of Defense. https://www.defense.gov/Explore/News/Article/Article/1829790/middle-eaststrategic-alliance-effort-aimed-at-stabilization/

Maher, N. (2020). Balancing deterrence: Iran-Israel relations in a turbulent Middle East. Review of Economics \& Political Science, ahead-of-print(ahead-of-print). https://doi.org/10.1108/REPS-06-2019-0085 
Mazzetti, M., Goldman, A., Bergman, R., \& Perlroth, N. (2019, March 21). A New Age of Warfare: How Internet Mercenaries Do Battle for Authoritarian Governments. The New York Times. https://www.nytimes.com/2019/03/21/us/politics/governmenthackers-nso-darkmatter.html

Totten, M. J. (2016). The New Arab-Israeli Alliance. World Affairs (Washington), 179(2), 28-36. https://doi.org/10.1177/0043820016673779

Middle East Monitor. (2014, September 27). Sanaa is the fourth Arab capital to join the Iranian revolution. https://www.middleeastmonitor.com/20140927-sanaa-is-thefourth-arab-capital-to-join-the-iranian-revolution/

Miller, S., \& Bunn, M. (2014). Interpreting The Implacable Foe: American Perceptions Of Iran. In A. Maleki \& J. Tirman (Eds.), U.S.-Iran Misperceptions : A Dialogue (pp. 57-88). essay.

https://scholar.harvard.edu/files/matthew bunn/files/bunn_miller_interpreting the im placable foe.pdf

Mirzoev, T. N., Zhu, L., Yang, Y., Zhang, T., Roos, E., Pescatori, A., \& Matsumoto, A. (2020). The Future of Oil and Fiscal Sustainability in the GCC Region. International Monetary Fund. https://www.imf.org/en/Publications/Departmental-Papers-PolicyPapers/Issues/2020/01/31/The-Future-of-Oil-and-Fiscal-Sustainability-in-the-GCC$\underline{\text { Region-48934 }}$

Mogherini, F. (2019, November 18). Statement by High Representative/Vice-President Federica Mogherini on Israeli settlement policy. European External Action Service. https://eeas.europa.eu/headquarters/headquartershomepage_en $/ 70610 /$ Statement $\% 20 \mathrm{by} \% 20 \mathrm{High} \% 20 \mathrm{Representative/Vice-}$ President $\% 20$ Federica $\% 20$ Mogherini $\% 20$ on $\% 20$ Israeli $\% 20$ settlement $\% 20$ policy 
Motamedi, M. (2021, February 22). Iran lawmakers call for president's prosecution over IAEA deal. A1 Jazeera. https://www.aljazeera.com/news/2021/2/22/iran-parliamentcall-for-president-be-punished-for-iaea-agreement

Mousavian, S. H., \& Mousavian, M. M. (2018). Building on the Iran Nuclear Deal for International Peace and Security. Journal for Peace and Nuclear Disarmament, 1(1), 169-192. https://doi.org/10.1080/25751654.2017.1420373

National Archives. (2021). Camp David Accords: The Framework for Peace in the Middle East.

https://www.jimmycarterlibrary.gov/research/framework for peace in the middle e $\underline{\text { ast }}$

Neuman, S., \& Kennedy, M. (2020, January 28). Trump Says His Mideast Peace Plan Provides A 'Realistic Two-State Solution'. NPR. https://www.npr.org/2020/01/28/800296507/white-house-to-unveil-mideast-peaceplan-despite-palestinian-rejection

Obaid, R. (2021, February 1). US secretary of state: Iran 'weeks away from having material to build nuclear bomb'. Arab News. https://www.arabnews.com/node/1801906/middle-east

Odeh, N. (2020, August 19). How the Israel-UAE alliance formalises new fault lines in the Middle East. The New Arab.

https://english.alaraby.co.uk/english/indepth/2020/8/19/how-the-israel-uae-alliance$\underline{\text { formalises-new-fault-lines }}$

Office of the Historian. (2016a). The Madrid Conference, 1991. https://history.state.gov/milestones/1989-1992/madrid-conference 
Office of the Historian. (2016b). The Oslo Accords and the Arab-Israeli Peace Process. https://history.state.gov/milestones/1993-2000/oslo

Orion, A., \& Montgomery, M. (2021, January 28). Moving Israel to CENTCOM: Another Step Into the Light. The Washington Institute.

https://www.washingtoninstitute.org/policy-analysis/moving-israel-centcom-anotherstep-light

Osama A. H. (2018). American Foreign Policy toward the Arab-Israeli Conflict. Insight Turkey, 20(2), 251-272. https://doi.org/10.25253/99.2018202.12

Pape, A. R. (2005). Soft Balancing against the United States. International Security, 30(1), 7-45. https://doi.org/10.1162/0162288054894607

Powaski, R. E. (2019). Ideals, interests, and U.S. foreign policy from George H.W. Bush to Donald Trump. Palgrave Macmillan

Quamar, M. M. (2018). Trump and West Asia: Policy Departures and Geopolitical Implications. India Quarterly, 74(3), 272-289. https://doi.org/10.1177/0974928418785478

Quero, J., \& Dessì, A. (2019). Unpredictability in US foreign policy and the regional order in the Middle East: reacting vis-à-vis a volatile external security-provider. British Journal of Middle Eastern Studies, 1-20. https://doi.org/10.1080/13530194.2019.1580185

Rabi, U., \& Mueller, C. (2017). The Gulf Arab states and Israel since 1967: from 'no negotiation' to tacit cooperation. British Journal of Middle Eastern Studies, 44(4), 576-592. https://doi.org/10.1080/13530194.2017.1360013

Razvi, M. (1981). The Fahd Peace Plan. Pakistan Horizon, 34(4), 48-61. http://www.jstor.org/stable/41394137 
Freedman, R. O. (2017). The Obama Legacy in the Middle East and the Trump

Challenge. India Quarterly, 73(2), 241-250.

https://doi.org/10.1177/0974928417699917

Rosenberg, R.-L. S. (2011). (working paper). Why Camp David II Failed: a Negotiation Theory Perspective. Harvard Negotiation Law Review. Retrieved from https://www.hnlr.org/wp-content/uploads/sites/22/2012/03/Rosenberg-NegotiationFinal-Paper-1.pdf

Ryan, C. R. (2009). Inter-Arab alliances : regime security and Jordanian foreign policy. University Press of Florida

Ryan, C. R. (2015, May 7). Regime security and shifting alliances in the Middle East. The Project on Middle East Political Science. https://pomeps.org/regime-security-and$\underline{\text { shifting-alliances-in-the-middle-east }}$

Sanger, D. E. (2016, December 28). Kerry Rebukes Israel, Calling Settlements a Threat to Peace. The New York Times. https://www.nytimes.com/2016/12/28/us/politics/johnkerry-israel-palestine-peace.html

Security Council Report. (2018, June 27). Iran Nuclear Agreement: Briefing on the Implementation of Resolution 2231.

https://www.securitycouncilreport.org/whatsinblue/2018/06/iran-nuclear-agreementbriefing-on-the-implementation-of-resolution-2231.php

Security Council Report. (2020, September 2). Iran Chronology of Events. https://www.securitycouncilreport.org/chronology/iran.php

Shepp, J. (2020, August 16). Why the Israel-UAE Deal Is More About Iran Than Peace. Intelligencer. https://nymag.com/intelligencer/2020/08/why-the-israel-uae-deal-is$\underline{\text { more-about-iran-than-peace.html }}$ 
Schmidt, B. C., \& Williams, M. C. (2008). The Bush Doctrine and the Iraq War:

Neoconservatives Versus Realists. Security Studies, 17(2), 191-220.

https://doi.org/10.1080/09636410802098990

Solhdoost, M. (2018, July 26). Trump's Foreign Policy Mantra: 'Whoever Pays For It!'. E-International Relations. https://www.e-ir.info/2018/07/24/trumps-foreign-policymantra-whoever-pays-for-it/

Stapleton, B. (2016, June 7). The Problem with the Light Footprint: Shifting Tactics in Lieu of Strategy. Cato Institute.

https://www.cato.org/sites/cato.org/files/pubs/pdf/pa792_1.pdf

Tessler, M. (2020). The Israeli-Palestinian Conflict. In E. Lust \& L. Khatib (Eds.), The Middle East (15th ed.). Thousand Oaks, California : CQ Press, an imprint of SAGE Publications

The Economist Intelligence Unit. (2018, April 3). Cyber attacks: is the GCC prepared? https://www.eiu.com/industry/article/806588464/cyber-attacks-is-the-gccprepared/2018-04-03

The National Interest. (2016, April 27). Trump on Foreign Policy. https://nationalinterest.org/feature/trump-foreign-policy-15960

The New Arab Staff. (2020a, August 16). Kuwait says won't budge from 'fixed' antinormalisation stance following UAE-Israel deal: reports. The New Arab.

https://english.alaraby.co.uk/english/news/2020/8/16/kuwait-says-wont-budge-from$\underline{\text { fixed-anti-normalisation-stance-reports }}$

The New Arab Staff. (2020b, September 4). Israel could build military base in UAE, Iranian report claims. The New Arab. 
https://english.alaraby.co.uk/english/news/2020/9/4/israel-could-build-military-basein-uae-iranian-report

The Secretary-General. (2018). Implementation of Security Council resolution 2231 (2015). United Nations. https://www.undocs.org/S/2018/602

The Washington Post. (2001, September 20). President Bush Addresses the Nation. https://www.washingtonpost.com/wp$\underline{\text { srv/nation/specials/attacked/transcripts/bushaddress_092001.html }}$

The White House. (2002b, January 29). President Delivers State of the Union Address. https://georgewbush-whitehouse.archives.gov/news/releases/2002/01/20020129$\underline{11 . h t m l}$

The White House. (2002a, September). The National Security Strategy. https://georgewbush-whitehouse.archives.gov/nsc/nss/2002/

The White House. (2002c, June 24). President Bush Calls for New Palestinian Leadership. https://georgewbushwhitehouse.archives.gov/news/releases/2002/06/20020624-3.html

The White House. (2015, September 10). Statement by the President. https://obamawhitehouse.archives.gov/the-press-office/2015/09/10/statementpresident

The White House. (2016, January 16). The Historic Deal That Will Prevent Iran from Acquiring a Nuclear Weapon. https://obamawhitehouse.archives.gov/issues/foreignpolicy/iran-deal

The White House. (2017, December). National Security Strategy of the United States of America. https://trumpwhitehouse.archives.gov/wp-content/uploads/2017/12/NSSFinal-12-18-2017-0905.pdf 
United Nations. (1979a, March 22). Resolution 446 (1979) of 22 March 1979.

https://unispal.un.org/UNISPAL.NSF/db942872b9eae454852560f6005a76fb/ba123cd $\underline{\text { ed3ea84a5852560e50077c2dc?OpenDocument }}$

United Nations. (1979b, July 20). Resolution 452 (1979) of 20 July 1979.

https://unispal.un.org/UNISPAL.NSF/db942872b9eae454852560f6005a76fb/0b7116a

bb4b7e3e9852560e5007688a0?OpenDocument

United Nations. (1981, December 17). Resolution 497 (1981).

https://unispal.un.org/DPA/DPR/unispal.nsf/0/73D6B4C70D1A92B7852560DF0064

$\underline{F 101}$

United Nations. (1982, September 1). Address to the Nation on United States Policy for Peace in the Middle East. https://www.un.org/unispal/document/auto-insert-207767/

UN News. (2015, July 14). UN applauds 'historic' deal on Iranian nuclear programme. https://news.un.org/en/story/2015/07/504202-un-applauds-historic-deal-iraniannuclear-programme

U.S. Department of State. (2015, July 14). Joint Comprehensive Plan of Action. https://2009-2017.state.gov/e/eb/tfs/spi/iran/jcpoa//index.htm

United States Institute of Peace. (2001, January 1). Clinton Proposal on IsraeliPalestinian Peace. https://www.usip.org/sites/default/files/Peace\%20Puzzle/10_Clinton\%20Parameters.p $\underline{\mathrm{df}}$

Vaughan, J. (2016, September 12). Deterring Iranian Provocations at Sea. The Washington Institute. https://www.washingtoninstitute.org/policy-analysis/deterringiranian-provocations-sea

Walt, S. M. (1987). The origins of alliances. Cornell University Press 
Walt, S. M. (2018). US grand strategy after the Cold War: Can realism explain it? Should realism guide it? International Relations (London), 32(1), 3-22.

https://doi.org/10.1177/0047117817753272

Wechsler, W. F. (2019). US Withdrawal from the Middle East: Perceptions and Reality. In K. Mezran \& A. Varvelli (Eds.), The MENA region: A great power competition (pp. 13-38). https://www.atlanticcouncil.org/in-depth-research-reports/report/themena-region-a-great-power-competition/

Yarhi-Milo, K. (2018). After Credibility: American Foreign Policy in the Trump Era. Foreign Affairs (New York, N.Y.), 97(1), 68

Yom, S. (2020). US Foreign Policy in the Middle East: The Logic of Hegemonic Retreat. Global Policy, 11(1), 75-83. https://doi.org/10.1111/1758-5899.12777

Zakaria, F. (2020, January 10). Trump does not have a foreign policy. He has a series of impulses. The Washington Post. https:/www.washingtonpost.com/opinions/globalopinions/trump-does-not-have-a-foreign-policy-he-has-a-series-ofimpulses/2020/01/09/03ae5592-3329-11ea-a053-dc6d944ba776_story.html

Zilber, N. (2019, January 17). Gulf Cyber Cooperation with Israel: Balancing Threats and Rights. The Washington Institute.

https://www.washingtoninstitute.org/pdf/view/1904/en 